\title{
FORMAÇÃO DE DEPRESSÕES SOBRE MATERIAIS DA FORMAÇÃO IRATI, EM PIRACICABA (SP)
}

\author{
EVERALDO DE CARVALHO CONCEIÇÃO TELLES \\ Engenheiro Agrônomo
}

Orientador: Prof. Dr. ANDREAS ATTLA WOLINSK MIKIÓS

Dissertação apresentada à Escola Superior de Agricultura "Luiz de Queiroz", Universidade de São Paulo, para obtenção do título de Mestre em Agronomia, Área de Concentração: Solos e Nutrição de Plantas.

Piracicaba

Estado de São Paulo - Brasil

Novembro - 1997 
Dados Internacionais de Catalogaçāo na Publicaçāo (CiP) DIVISĀO DE BIBLIOTECA E DOCUMENTAÇĀO - Campus "Luiz de Queiroz"/USP

Telles, Everaldo de Carvalho Conceição Formaçāo de depressōes sobre materiais da Formaçāo Irati, em Piracicaba / Everaldo de Carvalho Conceiçāo Telles. - - Piracicaba, 1997. 89 p. : il

Dissertaçāo (mestrado) - - Escola Superior de Agricultura Luiz de Queiroz, 1998. Bibliografia.

1. Calcário 2. Erosāo 3. Formação Irati 4. Geologia regional 5. Morfogenese 6. Pedologia 7. Rocha I. Título

CDD 631.4 


\section{FORMAÇÃO DE DEPRESSÕES SOBRE MATERIAIS DA FORMAÇÃO IRATI, EM PIRACICABA (SP)}

\section{EVERALDO DE CARVALHO CONCEIÇÃO TELLES}

Aprovada em: 19.01.1998

Comissão julgadora: "1000 40

Prof. Dr. Rafael Roberto Aloisi

ESALQ/USP

Prof. Dr. Carlos Roberto Espindola FEAGRI/UNICAMP

Prof. Dr. Andreas Attila de Wolísk Miklos ESALQ/USP
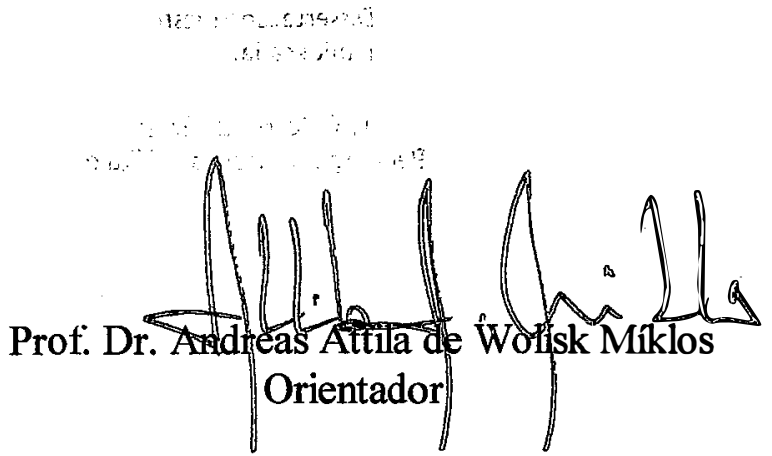
Dedico este trabalho a meus pais por

todo apoio e carinho.

Ofereço este trabalho a minha companheira Elenara pelo estímulo e amor e a minha filhinha Isis pela alegria e energia que me proporciona. 


\section{AGRADECIMENTOS}

Ao meu orientador, Dr. Andreas Attila de Wólisk Míklos, pela orientação e confiança, ao curso de Solos e Nutrição de Plantas pela oportunidade, ao CNPq pela bolsa de mestrado e a Escola Superior de Agricultura "Luiz de Queiroz". 


\section{FORMAÇÃO DE DEPRESSÕES SOBRE MATERIAIS DA FORMAÇÃO IRATI, EM PIRACICABA (SP)}

Autor: Everaldo de Carvalho Conceição Telles Orientador: Prof. Dr. Andreas Attila Wolinsk Miklós

\section{RESUMO}

Estudaram-se a formação de depressões fechadas e abertas que ocorrem, com frequêência, sobre materiais da Formação Irati na região de Piracicaba-SP. Tais depressões, de forma mais ou menos circular e com algumas dezenas de metros de diâmetro, aparecem sistematicamente em locais mal drenados.

Apesar dos poucos estudos sobre estas depressões, 3 hipóteses poderiam, em princípio, explicar a gênese destas depressões: 1) Erosão geoquímica interna da cobertura pedológica como mecanismo principal, com a perda de material em solução e rebaixamento do relevo; 2) Solubilização do material de origem, favorecido por uma rede de diacláses e fraturas, com posterior desabamento das estruturas superficiais e rebaixamento do relevo; 3) Diferentes tipos de dobras atectônicas.

Através de análises morfológicas da cobertura pedológica, procurou-se conhecer detalhadamente as diferentes organizações pedológicas existentes, nas diferentes escalas, da paisagem até as microestruturas. Para tanto, foram realizadas descrições morfológicas (de perfis, alteritas e representações bidimensionais), observações geológicas, análises micromorfológicas (microscopia ótica) análises granulométricas, químicas e mineralógicas (difração de raio X). 
O processo mais provável de formação da depressão estudada está relacionado a dobramentos atectônicos de expansão da montmorilonita dos folhelhos. Áreas mais silificadas ou mais distantes de prováveis contatos de maior fraturamento, devido às inversões ou maiores gradientes de mudança no nível de base, estariam mais preservadas deste tipo de dobramento. Estas áreas mais preservadas estariam nas posições mais baixas das depressões fechadas ou abertas que ocorrem sobre a Formação Irati.

O processo de diferenciação pedológica de materiais bem drenados avermelhados, passando a matizes mais amarelados e chegando a solos mais acinzentados com feições típicas de hidromorfismo, seria secundário, condicionado pelo desenvolvimento de hidromorfia em direção a base das depressões. A erosão geoquímica dos solos, neste caso, tem uma atuação secundária no desenvolvimento do relevo.

Estudos mais detalhados, envolvendo geologia estrutural e macro e micromorfologia de solos e alteração, em outras depressões semelhantes, em diferentes estágios de desenvolvimento seriam importantes para se compreender melhor a interação dos sistemas pedológicos associados e as suas relações com o modelado na Formação Irati. 


\title{
FORMING OF DEPRESSIONS ABOVE MATERIALS OF THE IRATI FORMATION IN PIRACICABA (SP)
}

\author{
Author: Everaldo de Carvalho Conceição Telles \\ Adviser: Prof. Andreas Attila Wolinsk Miklós
}

SUMMARY

Pedological systems and theirs relation with closed and opened depressions that frequently occur in Piracicaba-SP, during march of 1996 at october de 1997. Such depressions, presenting an approximately circular shape with the diameter by tens meters appear systematically in areas with poor drainage. In spite of the lack of studies an these depressions, 3 hypothesis or possibilities can, in a first moment explain there geneses: 1) Geochemical internal erosion of the pedological cover as a main mechanism, with the loss of material in solution and the lowering of the relief; 2) Solubilition of the originary material favour a net of fractures, followed the collaped of the superficial structure and lowering of the relief; 3) Diferent types of atectonics and atectonics folding; For such, morfological description (profiles and alterites), geological observations, soil micromorphological analysis (optic microscopy), granulometric, chemistry and mineralogic (X-Ray difraction) analysis were made. The most probable process of the studied depression is related atectonic folding, bring the pedological differentiation secondary, conditioned by the development of hidromorphy at the depression base direction. 


\section{SUMÁRIO}

Página

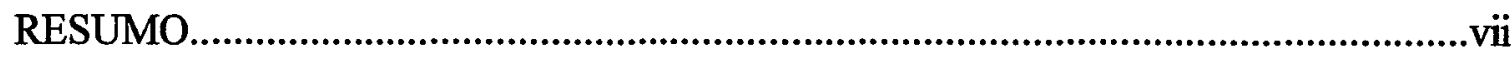

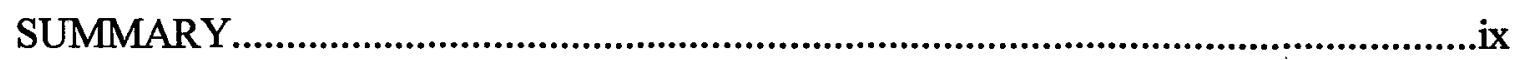

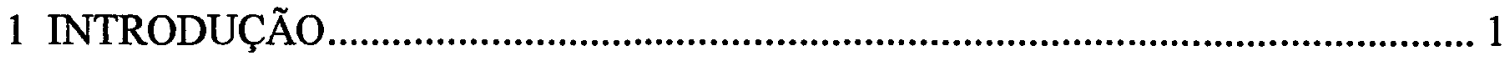

2 MATERIAL E MÉTODOS .............................................................................. 7

2.1.1 Localização da área de pesquisa ...................................................................... 7

2.2. Descrị̧ão Do Meio Físico ....................................................................................... 9

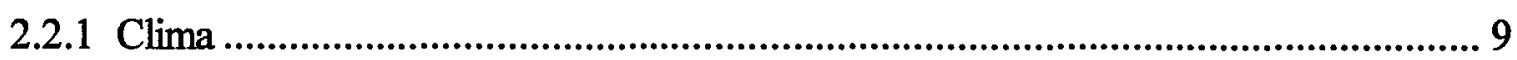

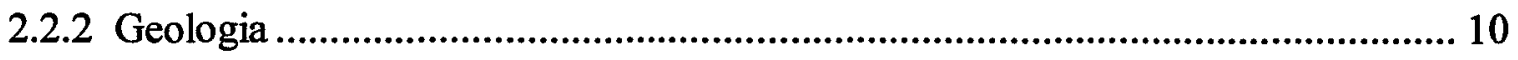

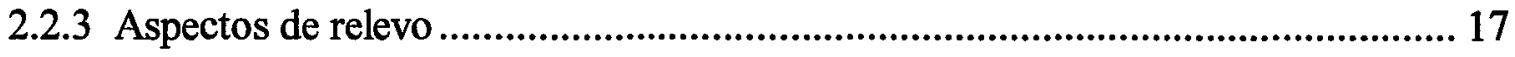

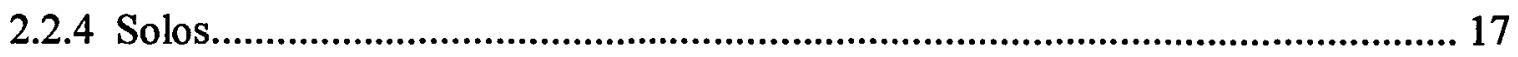

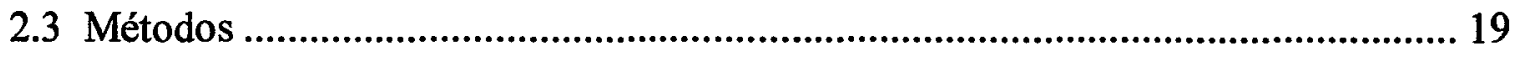

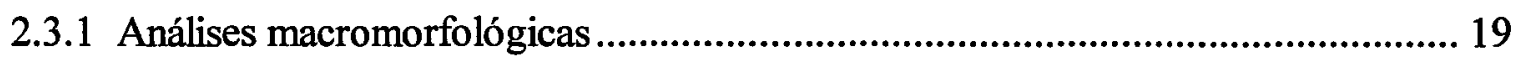

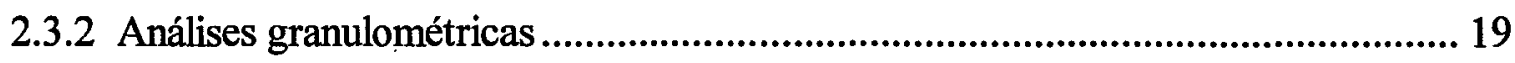

2.3.3 Análises químicas do complexo sortivo.............................................................. 20

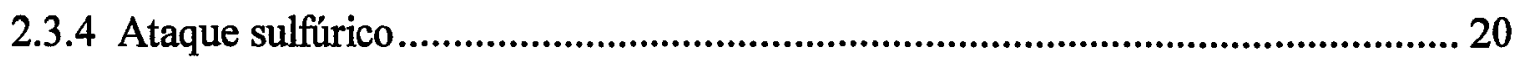

2.3.5 Mineralogia dâ fração argila ............................................................................. 20

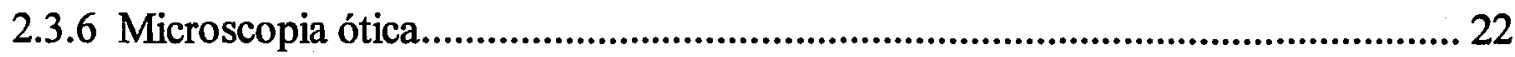

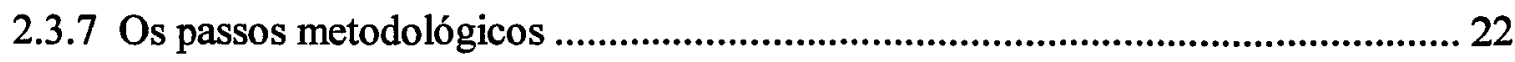

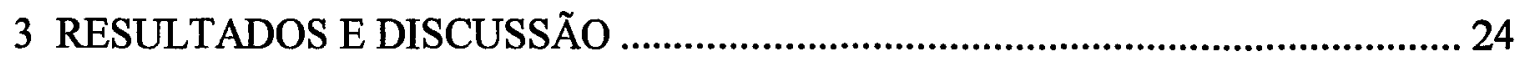

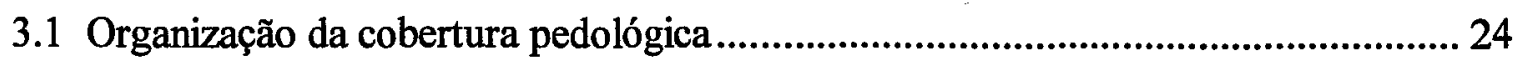




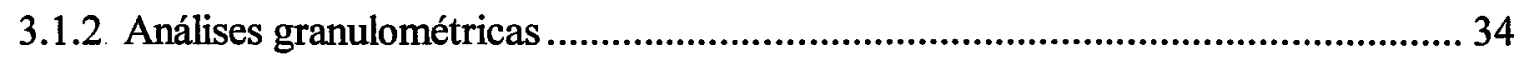

3.2 Mapeamento de deformações e taxa de mergulho do banco de calcário basal, do pacote de sedimentos, alteritas e solos nas pedreiras.................................................65

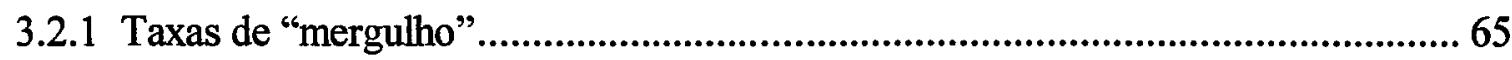

3.2.2 Deformações do terreno pela expansão diferenciada dos sedimentos.................... 71

3.3 Morfologia das alteritas na base das trincheiras da depressão estudada ................... 71

3.3.1 Alteritas do Perfil 1 ................................................................................................. 73

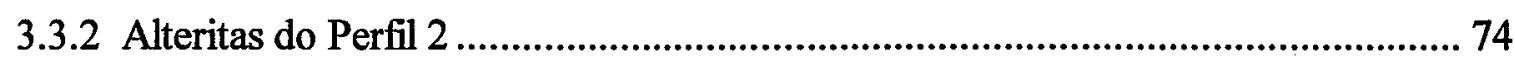

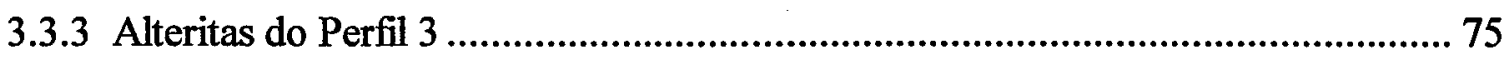

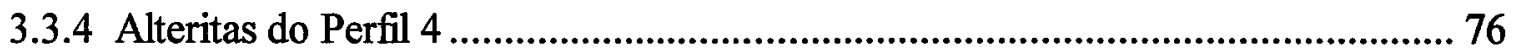

3.4 Evidências dos principais mecanismos e processos atuantes na formação das depressões e diferenciação de solos ......................................................................... 77

3.4.1 Erosão geoquímica da rocha e formação de dolinas com posterior desenvolvimento

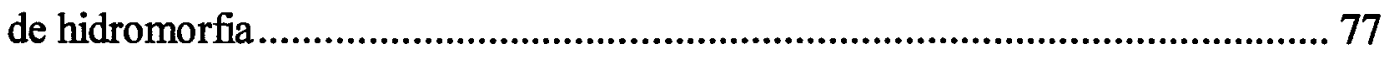

3.4.2 Erosão geoquímica do solo com formação da depressão e posterior processo hidromorfia acelerando o processo de rebaixamento do relevo ............................ 78

3.4.3 Dobramentos atectônicos ou de intemperismo favorecidos por uma silicificação diferencial da rocha e condicionando o desenvolvimento da depressão e sistemas

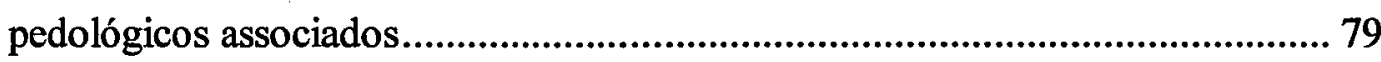

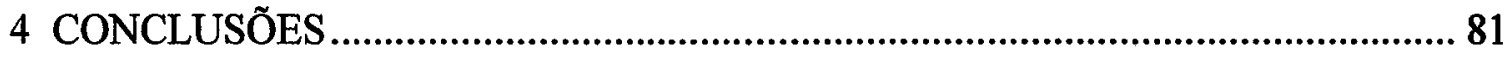

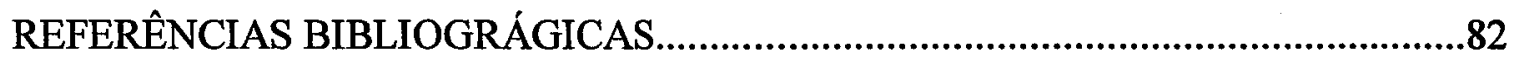

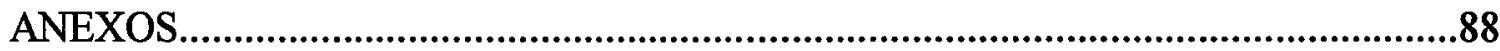




\section{INTRODUÇÃO}

Na região de Piracicaba (SP) ocorrem, com frequiência, depressões decamétricas mais ou menos circulares, fechadas ou abertas, desde alguns centímetros até alguns metros de desnível do topo à base. A literatura fornece diferentes hipóteses para explicá-las.

Françoso et al. (1974) explicam a formação de depressões doliniformes no platô de Itapetininga-SP, sobre calcários das formações Estrada Nova- Irati do Grupo Passa Dois e diabásios da Formação Serra Geral, a partir da alteração e solubilização destas rochas, com posterior abatimento da superfície e desenvolvimento de solos hidromórficos. As depressões, sobre rochas básicas, são interpretadas com uma alteração mais acelerada destas rochas, facilitada pela existência de uma rede de fraturas. Espindola et al. (1981) interpretam de forma semelhante às depressões fechadas estudadas sobre basaltos do Formação Serra Geral, na região de Jaú.

Reeves et al. (1975) mencionam que a água de percolação, dissolvendo, preferencialmente, rochas mais solúveis, poderia esculpir o relevo em decorrência de abatimentos superficiais subseqüentes.

Falhamentos da rocha, favorecendo a dissolução do banco de calcário da Formação Irati e posterior assentamento são comuns na região de Piracicaba (Amaral, 1971). 
Tais hipóteses condicionam, portanto, a formação das depressões ao abatimento do material superficial, em consequência da erosão preferencial do substrato rochoso em profundidade. No caso das regiões calcárias, a formação de dolinas de dissolução ou de desmoronamento de teto de caverna subterrânea provocaria o abatimento da superficie e a formação da depressão fechada ou aberta.

Segundo Hills (1963), a hidratação de folhelhos pode provocar dobramentos por expansão da argila da Formação Wianamatta - New South Wales com elevação dos materiais acima destes.

Landim (1965) relata que nos materiais da Formação Irati existe dois tipos de deformações: 1) deformações devido às intrusões de rochas básicas do Formação Serra Geral; 2) deformações devido à expansão do folhelho por hidratação, auxiliada tanto pelo alívio de pressão, quanto pela dissolução das camadas acima da deformação. As deformações devido à intrusões magmáticas ocorrem por todo o pacote de sedimentos e as deformações devida à expansão do folhelho apenas acima do nível hidrostático.

Amaral (1971) estudando os aspectos estruturais da Formação Irati na região de Piracicaba-SP, relata falhas tectônicas pós deposicionais, provocadas pela intrusão de diabásio e dobras atectônicas induzidas pela hidratação do folhelho contendo montmorilonita. Durante o processo de sedimentação, podem ter sido geradas deformações pelos deslizes da lama calcária e a intrusão da lâmina calcária nos folhelhos ainda plásticos. As dobras atectônicas, produzidas pela hidratação do folhelho, são relativamente comuns nas camadas rítmicas da Formação Irati em São Paulo, produzindo ligeiros abaulamentos até dobras bem pronunciadas, sendo as demais raras ou localizadas Portanto, estas depressões poderiam ser deformações litoherdadas do material de origem.

Em coberturas pedológicas da África Ocidental, Boulet et al. (1977) demonstram ser a erosão geoquímica do solo o primeiro mecanismo responsável pela perda de material e volume e, conseqüentemente, a evolução do modelado. Vários outros autores demostram a relação íntima entre a dinâmica geoquímica do solo e as formas de 
relevo (Millot, 1977; Bocquier et al., 1977; Chauvel et al., 1977 e Nahon \& Millot, 1977).

Estudando depressões fechadas sobre sedimentos quartzo cauliníticos em Caçapava-SP, Filizola \& Boulet (1993) atribuem sua formação à erosão geoquímica superficial. Estimou-se a taxa de afundamento geoquímico em 0,12 a $0,23 \mathrm{~mm} / \mathrm{ano}$, através da datação radiocarbônica de turfas.

Esta hipótese associa, portanto, a evolução do relevo à diferenciação pedológica.

Assim sendo, para estudar a gênese das depressões na região de Piracicaba e solos associados, admitem-se, de início, 3 hipóteses:

a) Deformações litoherdadas de diferentes tipos, mais comumente as originadas por dobras atectônicas pós deposicionais, provocadas pela hidratação de folhelhos montmoriloníticos. O grau e a quantidade de fraturamentos das rochas induziriam o grau e a extensão destas deformações.

b) Erosão geoquímica preferencial do substrato rochoso, com posterior abatimento do material superficial e rebaixamento do relevo.

c) Rebaixamento do relevo a partir da erosão geoquímica do solo. A formação das depressões estaria condicionada à diferenciação pedológica.

A estas hipóteses poder-se-ia associar a própria variabilidade espacial da Formação Irati, que embora Amaral (1971), relate uma grande homogeneidade litológica em toda sua extensão, também comenta que são relativamente comuns lâminas de sílex de alguns milimetros até alguns centímetros, que podem ser descontínuas. Esta. descontinuidade poderia induzir diferentes graus de intemperismo nestes materiais.

$\mathrm{O}$ conhecimento da dinâmica pedomorfogenética atual e pretérita, controlando a gênese e evolução dos solos e do modelado, pode contribuir não só para interpretações relacionadas à pesquisa fundamental, mas também, para questões ligadas à evolução das vertentes, uso e manejo dos solos. 


\section{Objetivo}

A partir do estudo detalhado das organizações e processos atuantes na formação e evolução das depressões, procurar-se-á estabelecer a hierarquia e a cronologia entre as diferenciações pedológicas e litológicas, chegando-se a um diagnóstico mais preciso da dinâmica morfogenética atual.

\section{Hipóteses de trabalho}

Para alcançar o objetivo proposto, baseado nas hipóteses levantadas na literatura, construíram-se as seguintes hipóteses básicas de trabalho:

1.O mapeamento de lajes espessas de sílex no centro das depressões concordantes com o relevo e descontínuas, provocando um impedimento de drenagem na base das depressões, afirmará a erosão geoquímica do solo como o principal condicionante na formação das depressões e sistemas pedológicos associados (figura 1).

\section{EROSÃO GEOQUÍMICA DO SOLO}

\begin{tabular}{l}
\hline SOLO \\
\hline LAJE DE SILEX \\
ROCHA \\
$\begin{array}{l}\text { ROCHA MAIS } \\
\text { SOLÚVEL }\end{array}$ \\
\hline
\end{tabular}

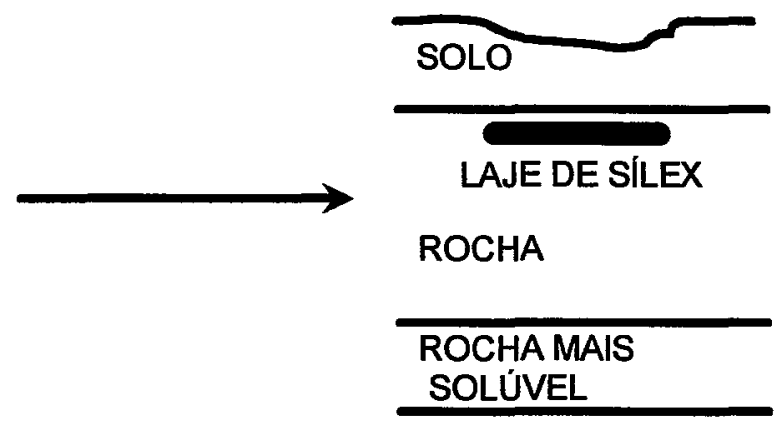

Figura 1- Exemplo hipotético de erosão geoquímica do solo condicionado, no caso, por um desequilibrio da cob` rura pedológica provocado por um impedimento da drenagem no centro da depressão sobre materiais da Formação Irati. 
2. As depressões doliniformes ou dolinas, como mecanismo principal da formação das depressões e sistemas pedológicos associados, serão confirmadas pela não observação da hipótese anterior e o baixo grau de organização litológica $e$ pedológica provocada pelo desmoronamento do teto de cavernas, com o fraturamento mais intenso da rocha e desnivelamento das diferentes camadas litológicas $e$ pedológicas.

\section{DOLINAS OU PSEUDO DOLINAS}
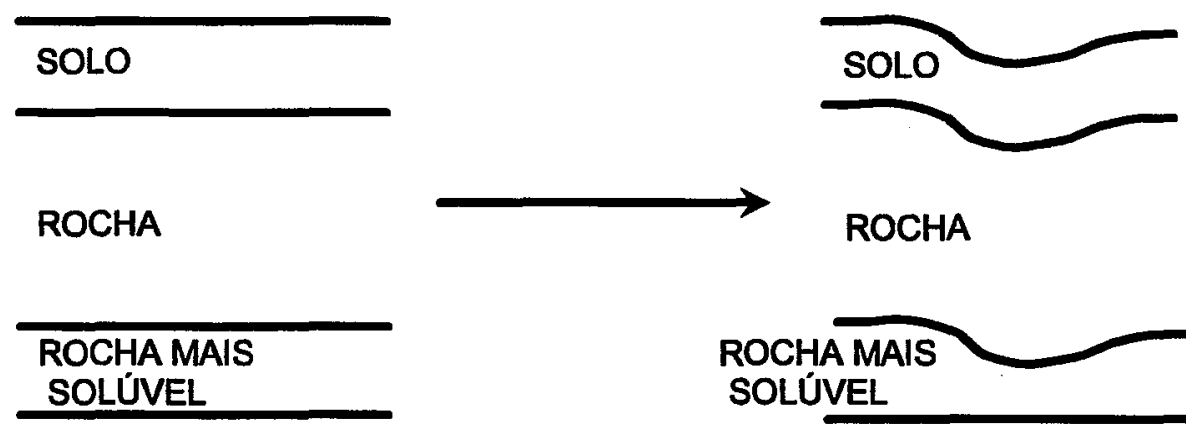

ROCHA
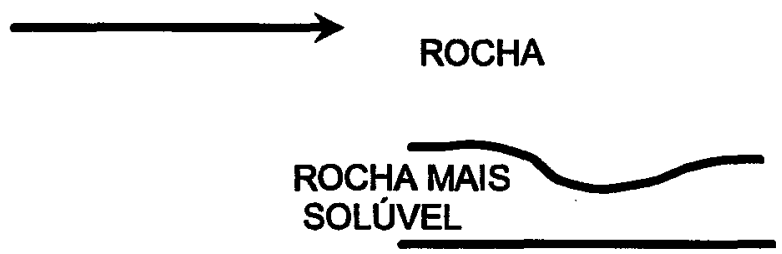

Figura 2 - Exemplo hipotético dos estágios inicial e final da formação de dolinas por um fraturamento mais intenso da rocha, facilitando a penetração da água, dissolução $e$ remoção da rocha mais solúvel em profundidade, com posterior desabamento do teto da caverna formada e rebaixamento do relevo. 
3. O mapeamento de litorrelíqueas de silex (bonecas, lâminas, plaquetas e leitos) assim com volumes de alteração concordantes com o relevo deste do centro da depressão afirmará uma expansão diferenciada do material de origem e ou dos volumes de alteração sob a cobertura pedológica. A depressão seria litoherdada e a diferenciação pedológica condicionada por esta (figura 3 ).

\section{DOBRAMENTOS ATECTONICOS}
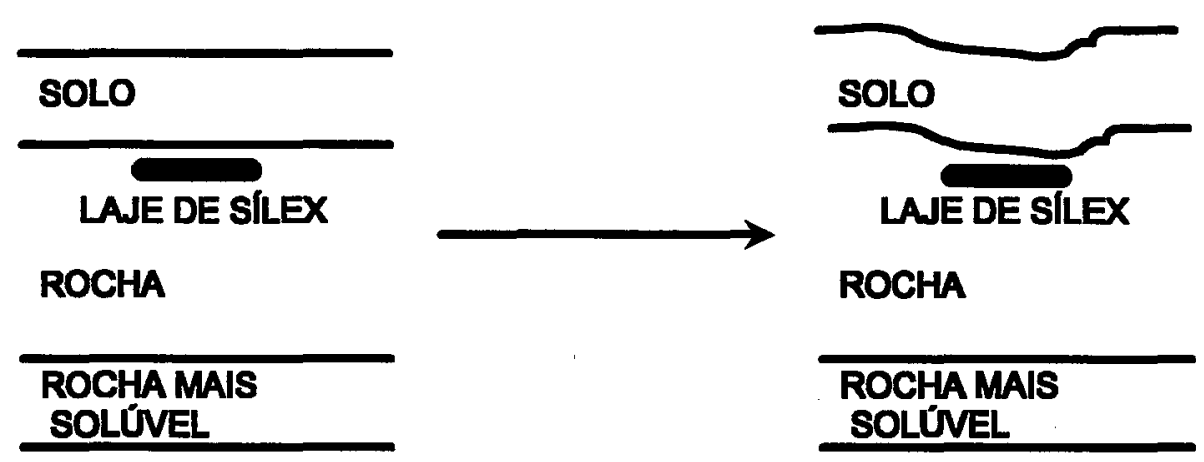

Figura 3 - Exemplo hipotético dos estágios inicial e final da formação de depressões devido a dobramentos atectônicos sobre materiais da Formação Irati. A laje espessa de sílex descontínua no centro da depressão condiciona uma hidratação, alteração $e$ expansão diferenciada da rocha. 


\section{MATERIAL E MÉTODOS}

\subsubsection{Localização da área de pesquisa}

A área de estudo situa-se nas proximidades de Arraial de São Bento, município de Saltinho ( $22^{\circ} 55^{\prime} \mathrm{S}$ e $47^{\circ} 43 \mathrm{~W}$ ), a $35 \mathrm{Km}$ ao sul de Piracicaba (figura 4), com a altitude aproximada de $540 \mathrm{~m}$, segundo a folhas planialtimétricas de Bairrinho, na escala 1:10.000. (figura 5).

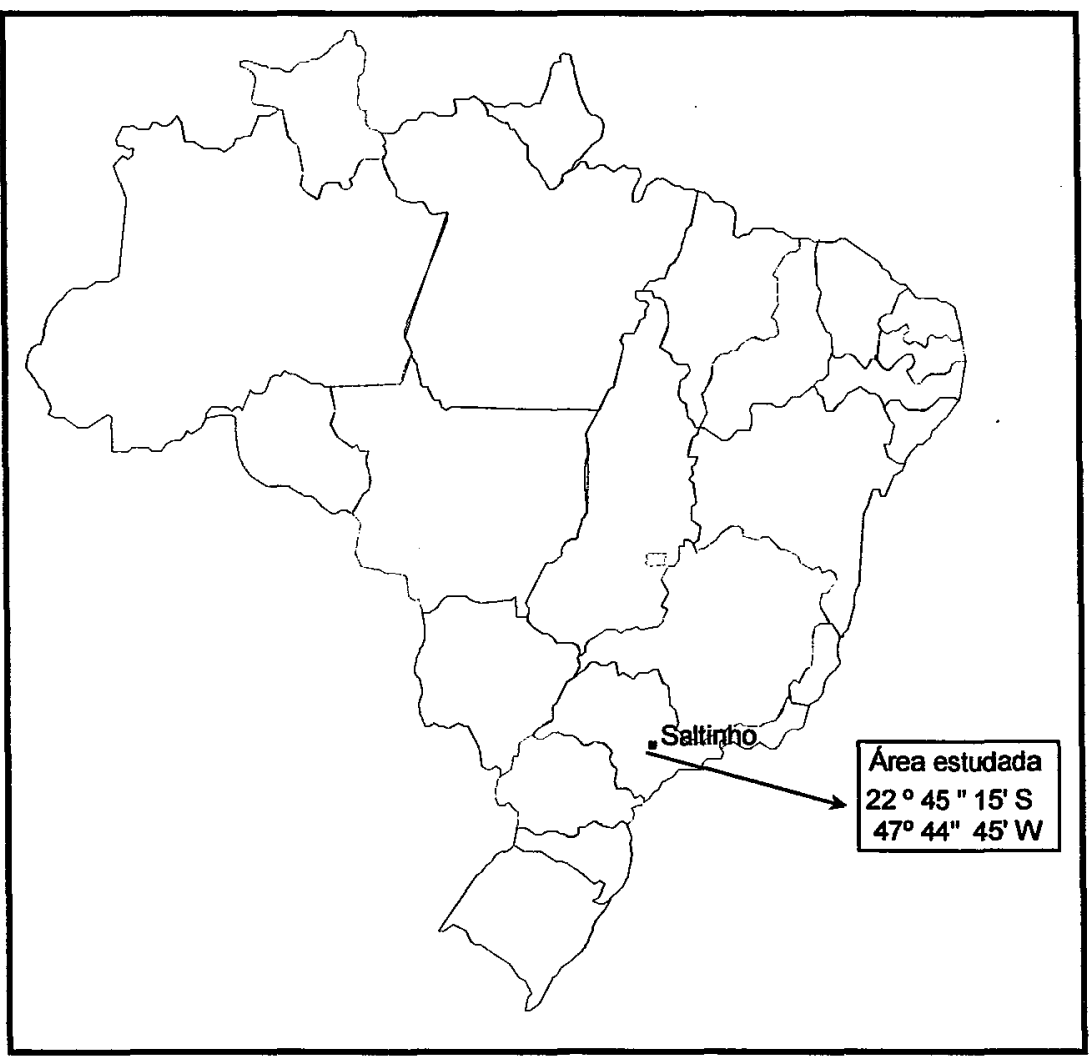

Figura 4 - Esquema de localização da área estudada. 


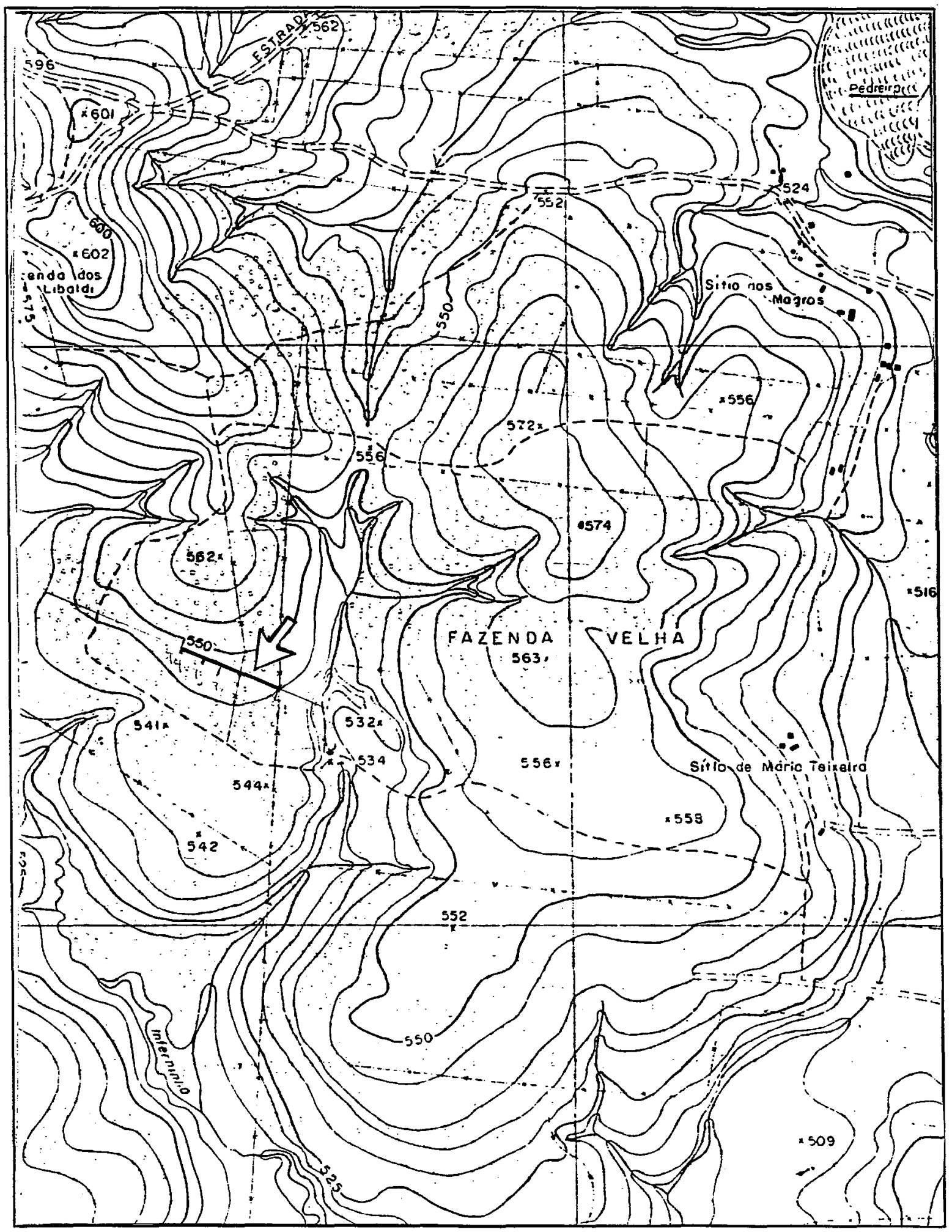

Figura 5 - Localização da área e toposseqüência (seta branca) na carta planialtimétrica na escala 1:10.000 do IGC-1977. 
Na figura 6 uma visão geral da região e depressão estudada.

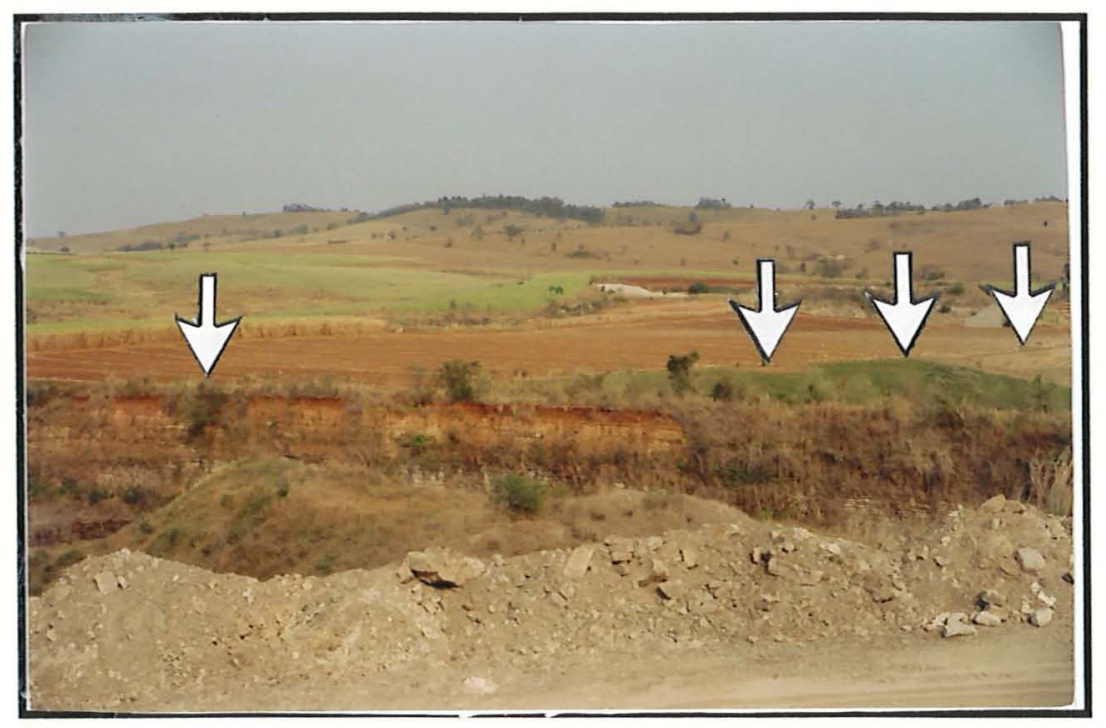

Figura 6 - Vista geral da área e depressão estudada com mancha mais clara de solo a esquerda da foto, com forma bem irregular e localização aproximada dos perfis estudados (setas brancas).

\subsection{Descrição do meio físico}

\subsubsection{Clima}

O clima regional, segundo Koppen, é do tipo mesotérmico Cwa, subtropical úmido, com estiagem no inverno. A pluviosidade média é de $1200 \mathrm{~mm}$ e as chuvas do mês mais seco não atingem $30 \mathrm{~mm}$. A temperatura do mês mais quente é superior a $22^{\circ} \mathrm{C}$, enquanto a do mês mais frio é inferior a $18^{\circ}$ (Comissão De Solos, 1960). 
A vegetação primitiva pode ser encontrada na região em alguns fragmentos isolados de Floresta Latifoliada Tropical.

A região acompanhou os grandes ciclos agrícolas. No século passado a cultura dominante era o café, seguindo-se o ciclo do algodão até a década de $20 \mathrm{e}$ atualmente a lavoura de cana-de-açúcar.

\subsubsection{Geologia}

Segundo o IPT (1981a), a Formação Irati situa-se na base do Grupo Passa Dois. É delimitada inferiormente pela Formação Tatuí, do Grupo Tubarão, e na porção superior, na região de Piracicaba, pela Formação Serra Alta ou Formação Corumbataí (figura 7).

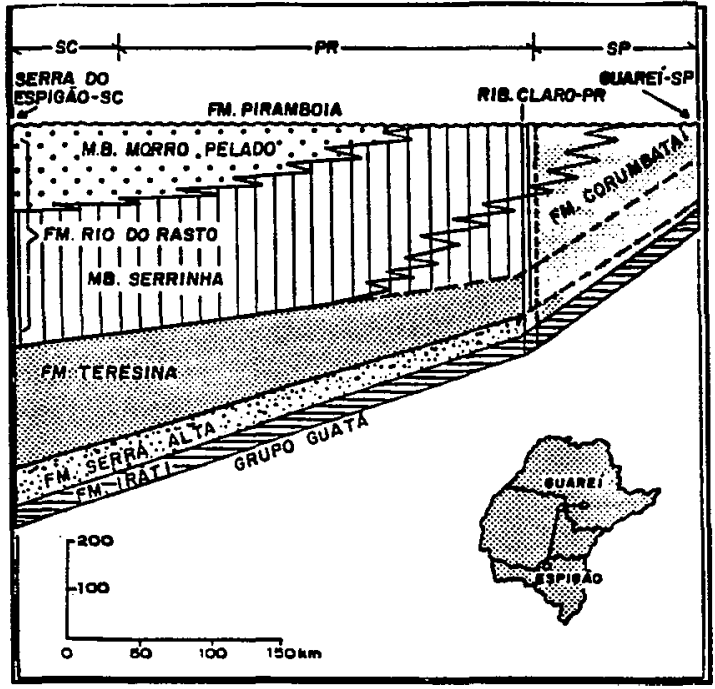

Figura 7 - Relações estratigráficas do Grupo

Passa Dois, SC-PR-SP (FONTE: IPT, 1981a).

A Formação Tatuí, na sua base, é predominantemente constituída de siltitos de cor marrom-arroxeada, às vezes brancos, finamente laminados. Localmente incluem arenitos finos com estratificação plano-paralela, assim como delgadas camadas calcárias de cor cinzenta arroxeada e sílex. A porção superior também é de natureza siltica, porém tem cores cinza-esverdeada, amarelo-esverdeada e verde. São freqüentes as intercalações de arenito fino, maciço, com pequenas concreções calcárias. Podem ocorrer 
bancos de calcários, assim como conglomerados com seixos angulosos a arredondados de quartzo e silex com até $5 \mathrm{~cm}$ de diâmetro.

A Formação Irati foi subdividida, por Barbosa \& Gomes (1958), nos membros Taquaral (base) e Assistência (superior). A passagem entre ambos é gradual.

O Membro Taquaral, de natureza predominantemente pelítica, é composto de argilitos, folhelhos de cor cinza clara a escura e siltitos. Na base pode ocorrer camada delgada de arenito de granulação fina a grossa, seixoso, ou conglomerado com seixos de sílex e quartzo de até $5 \mathrm{~cm}$ de diâmetro (Barbosa \& Gomes, 1958; IPT, 1981a).

Membro Assistência é caracterizado, predominantemente, pela presença de dolomitos e calcários parcialmente dolomitizados e de folhelhos pirobetuminosos e piritosos, com leitos, lâminas e pederneiras de sílex castanho-escuro ou negro. $O$ sílex é menos abundante no topo da formação e o calcário (mais comum o dolomítico) economicamente explorável, ocorre entre 8 a 10 metros do contato com o membro Taquaral (Barbosa \& Gomes, 1958). A espessura do Membro Assistência alcança de 30 a 50 metros (IPT, 1981a). 
Segundo Amaral (1971), os materiais da Formação Irati têm a seguintes características, conforme o quadro 1 :

\begin{tabular}{|c|c|}
\hline MATERIAL & CARACTERISTICAS \\
\hline FOLHELHO & $\begin{array}{l}\text { Ligeiramente betuminoso, com coloração preta a cinzenta escura, podem apresentar } \\
\text { lâminas lenticulares de calcário de } 0.5 \text { a } 1 \mathrm{~cm} \text { de espessura ou intercalaçôes } \\
\text { miliméticas de siltito cinza claro. Possuem folheação quase perfeita e o } \\
\text { argilomineral que domina é a montmorilonita. Os nódulos de silex são muito } \\
\text { abundantes e obedecem a estratificação. }\end{array}$ \\
\hline $\begin{array}{c}\text { BETUME NOS } \\
\text { CALCÁRIOS }\end{array}$ & $\begin{array}{l}\text { Correspondem as camadas mais escuras dentro das camadas castanho escuro de } \\
\text { calcário, podem se dispor também em fragmentos dispersos na matriz branca de } \\
\text { calcário. Nas zonas castanhas encontrou-se } 6,6 \% \text { de material betuminoso. O betume } \\
\text { é comumente encontrado em pequena quantidade, } 1 \text { a } 2 \% \text {, mais ao redor de } 0,5 \% \text { de } \\
\text { pirobetume. Pode ainda ocorrer distribuido ao longo de fissuras ou de zonas mais } \\
\text { porosas, provavelmente migrado, nestes casos sua coloração é bem preta, } \\
\text { assemelhando-se a um piche endurecido. Neste tipo de betume encontramos restos } \\
\text { vegetais silificados. Outra maneira que ocorre o betume é na forma líquida, } \\
\text { preenchendo pequenas cavidades no calcário e quando exposto ao ar endurece, se } \\
\text { torna quebradiço. É escuro e inodoro, e quando queimado emite uma fumaça preta e } \\
\text { cor cheiro de asfalto queimado. }\end{array}$ \\
\hline $\begin{array}{l}\text { BETUME NOS } \\
\text { FOLHELHOS }\end{array}$ & $\begin{array}{l}\text { São raros os betumes solúveis em éter, uma pequena quantidade pode ser solúvel } \\
\text { em bromofórmio, não se tratando de betume ou pirobetume. As substâncias } \\
\text { pirobetuminosas eventualmente existentes podem atingir até } 10 \% \text { de pirobetume. } \\
\text { Tanto o betume encontrado nos calcários, como nos folhelhos, dão a rocha um odor } \\
\text { fétido de substâncias orgânicas cujas composiçôes químicas são complexas. }\end{array}$ \\
\hline
\end{tabular}


Quadro 1. Continuação

\begin{tabular}{|c|c|}
\hline MATERIAL & CARACTERISTICAS \\
\hline SILTITO & $\begin{array}{l}\text { São atípicos, possuindo fratura concóide muito semelhante às rochas da Formação } \\
\text { Corumbatai. }\end{array}$ \\
\hline SÍLEX & $\begin{array}{l}\text { Mais encontrado na porção inferior das camadas rítmicas, acima do banco de } \\
\text { calcário, compondo } 25 \% \text { em volume, que pode ser maior devido à abundância de } \\
\text { sílex nas camadas de folhelhos de mesma cor (não quantificado) e geralmente em } \\
\text { camadas de alguns } \mathrm{cm} \text { até } 20 \mathrm{~cm} \text { de espessura de forma contínua ou não, } \\
\text { substituindo os calcários total ou parcialmente na zona rítmica. O sílex na forma de } \\
\text { leito é geralmente preto, as vezes castanho, cinzento ou ligeiramente creme. É ainda } \\
\text { frequente a ocorrência de leitos de silex cinzento dentro de siltito amarelado de } \\
\text { origem posterior. Existem ainda as lâminas de sílex dispostas descontinuamente } \\
\text { com espessura de } 1 \text { a } 5 \text { milímetros, espaçadas de } 5 \text { a } 20 \mathrm{~cm} \text {, ocorrendo tanto no } \\
\text { banco de calcário como nas zonas rítmicas. }\end{array}$ \\
\hline $\begin{array}{c}\text { BONECAS DE } \\
\text { SÍLEX }\end{array}$ & $\begin{array}{l}\text { São nódulos esféricos, coalecidos que formam as bonecas. São comumente mais } \\
\text { achatados segundo o plano de orientação. Predominam nódulos centimétricos, } \\
\text { ocorrendo ainda os milimétricos. SÃO TíPICAS DA FORMAÇÃO IRATI. Ocorrem } \\
\text { tanto no calcário como no folhelho da zona rítmica, onde são mais abundantes. } \\
\text { Podem se concentrar tanto em um determinado leito de calcário como caoticamente. } \\
\text { Encontra-se pirita finamente dividida concentrada nos nódulos quando em contato } \\
\text { com o folhelho. }\end{array}$ \\
\hline $\begin{array}{l}\text { CAMADAS DE } \\
\text { CALCÁRIO }\end{array}$ & $\begin{array}{l}\text { Mais comuns os dolomíticos, geralmente maciços, de tonalidades claras (cremes ou } \\
\text { cinzentas), e muitas vezes, são totalmente ou irregularmente substituidas por sílex } \\
\text { (pretos ou cinzentos). A relação mais freqüente entre as camadas de folhelho é de } \\
1: 2 \text { ou } 3 \text { de calcário, sendo encontrados variaçães anormais em } 20 \text { metros } \\
\text { horizontais de } 1 \text { de follhelho para } 2 \text { de calcário para } 1 \text { de calcário para } 4 \text { de folhelho. } \\
\text { Microscopicamente é muito semelhante ao calcário do banco. }\end{array}$ \\
\hline $\begin{array}{l}\text { BANCO DE } \\
\text { CALCÁRIO }\end{array}$ & $\begin{array}{l}\text { Dolomítico calcítico, dolomíticos e calcário, se alternam nas camadas do banco, } \\
\text { sendo os primeiros mais abundantes. }\end{array}$ \\
\hline
\end{tabular}


Segundo Landim (1967), estes materiais se dispõem conforme a figura 8.

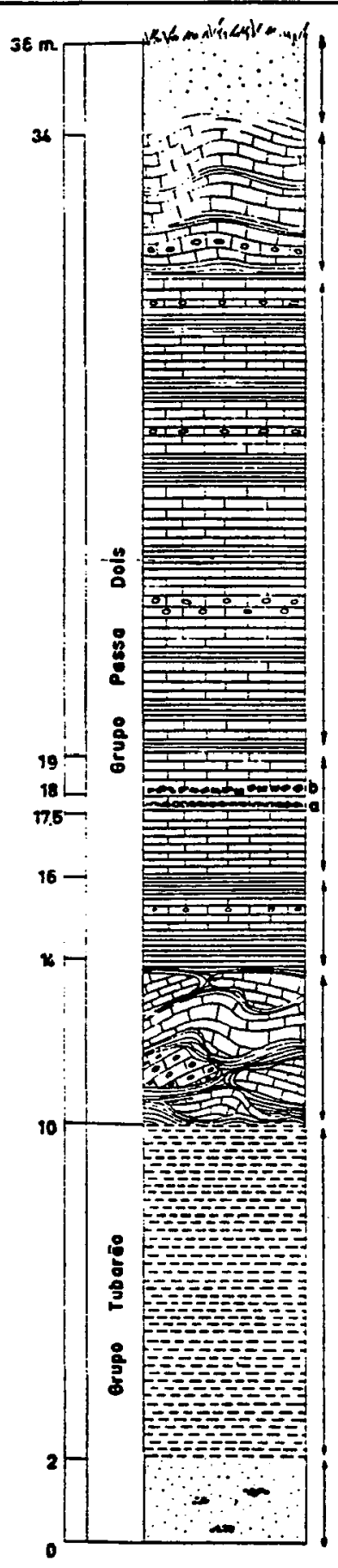

VIII. Solo avermelhodo

VII. Dobros tothas devido ao intemperismo

vi. Sequencia típiea do Iratí Paulista com al. ternancia de folhelho pirobetuminoso do. lomito

V. Banco dolomitico em exploracão

IV. Folhetho predominante com camadas de dolomito.teitos $e$ bonecas de silex

III. Lentes de dolomito no folhelho, dobrados lalnedas

II. Stlkito einza-eloro

1. Arenito amarelo grosseiro com lentes con. giomerdtleas estrutura de corrente

Figura 8 - Corte geológico em Assistência, na Região de Piracicaba- SP. 
A Formação Corumbataí, segundo o IPT (1981a) apresenta siltitos, argilitos e folhelhos cinzentos e roxo acinzentado. Segue-se com camadas siltosas, ritmicamente alternadas com lâminas ou delgadas camadas de litologia, variando de argilosa a arenosa fina, tanto vertical quanto horizontalmente. As cores vermelhas e arroxeadas passam a predominar no meio e na parte superior da formação, que apresentam também lentes e bancos de calcário com até meio metro de espessura. Sua espessura geralmente é inferior a 150 metros e repousa concordantemente sobre a Formação Irati. 
A carta geológica do IPT (1981a), na escala 1:500.000, ampliado 4 vezes (figura 9), apresenta as Formações geológicas na área estudada.

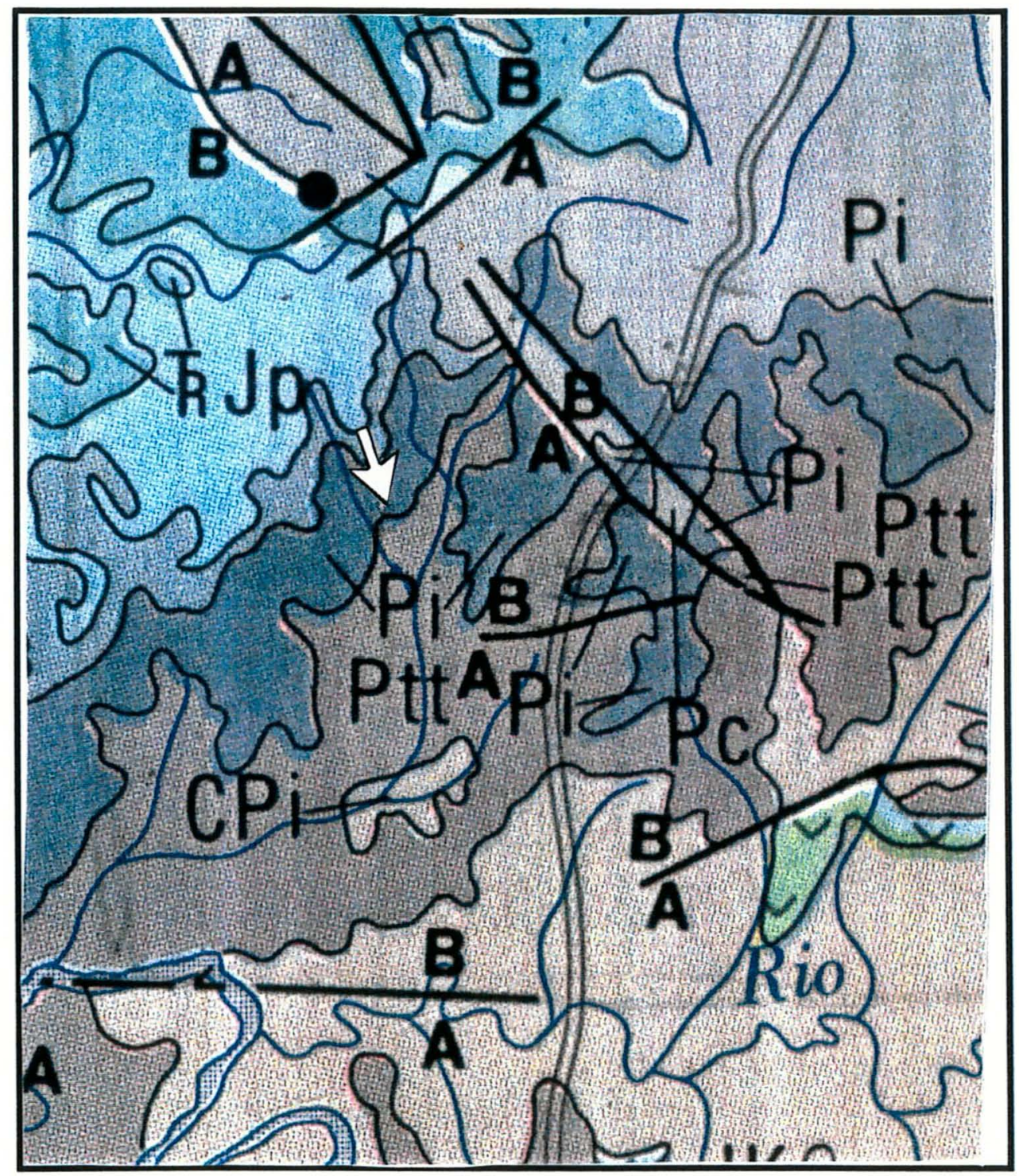

Figura 9 - Formações geológicas na área de estudo (seta branca), ampliado 4 vezes. Siglas utilizadas: $\operatorname{Tr} J p=$ Formação Pirambóia, $P i=$ Formação Irati, Ptt $=$ Formação Tatui, $C P i=$ Formação Itararé, $P c=$ Formação Corumbataí. As letras $A$ e B indicam falhamento de gravidade ou movimento de blocos $(A=$ alto, $B=$ baixo $)$. 


\subsubsection{Aspectos de relevo}

A região de Piracicaba situa-se na zona do Médio Tietê, que corresponde à área da Depressão Periférica drenada para o Rio Tietê (Almeida, 1964).

Segundo o IPT (1981b), predominam nesta zona relevos de colinas amplas e colinas médias e ainda morrotes alongados e espigões, principalmente no interflúvio dos rios Tiête-Piracicaba ao sul de Piracicaba.

A intercalação de estratos litologicamente diferentes, dentro do Grupo Passa Dois, introduz uma grande variação nos padrões do relevo, dificultando a delimitação de áreas e ocasionando a ocorrência de zonas híbridas. A região de Ibitiruna, no interflúvio dos rios Piracicaba-Tiête e característica desta situação, embora classificada como relevo de morrotes alongados e espigões, exibe topos chatos dos morros baixos, superficies onduladas, que seriam enquadradas como colinas médias em uma carta de detalhe.

\subsubsection{Solos}

Segundo a carta de solos da quadrícula de Piracicaba na escala 1:100.000 (Oliveira \& Prado, 1989), ocorrem na área PE: grupamentos indiscriminados de Podzólico Vermelho Escuro, textura argilosa ou argilosa/muito argilosa, com ou sem cascalho (Typic Paleudult, Typic Paleodalf e Typic Argiudoll); PL: grupamentos indiscriminados de Planossolos Ta, A moderado (Albiaquic, Paleudalf, Vertic Paleudalf e Epiaquic Tropudult); Li-1: Litólico eutrófico, vértico, A moderado, sedimentos indiscriminados (Vertic Lithic Hapludoll); Li-2: Litólico Eutrófico ou distrófico, A moderado, proeminente ou chernozêmico, textura média, substratos sedimentos indiscriminados do Grupo Tubarão (Typic Udorthent); Li-3: solos Litólicos Eutróficos ou Distrófico, A moderado ou proeminente, substratos indiscriminados do grupo Passa-Dois (Li-3) (Typic Udorthent); PV-3: Podzólicos Vermelho Amarelo, Planossólico, Eutrófico Ta, A moderado, textura média/argilosa, unidade Tiete (Albiaquic ?, Paleudalt, Albiaquic? Vertic Paleudalf); PV-9: grupamento indiscriminado de Podzólico Vermelho 
Amarelo, Tb abruptos, A moderado, textura arenosa/argilosa ou média/argilosa, Unidade Santa Cruz (Abruptic Paleudalf, Abruptic Arenic Paleudalf, Abruptic Paleudult e Abruptic Arenic Paleudult); PV-10: grupamento indiscriminado de Podzólico Vemelho Amarelo, A moderado, textura média/argilosa pouco profundos. Unidade Manduca (Abruptic Paleudalf e Typic Paleudalf) e G-1: grupamento indiscriminado de Gleis pouco húmicos (Aquox, Aquult, Aquept e Aqualf). Na figura 10 os solos mapeados na área estudada segundo a carta de solos da quadrícula de Piracicaba (Oliveira \& Prado, 1989).

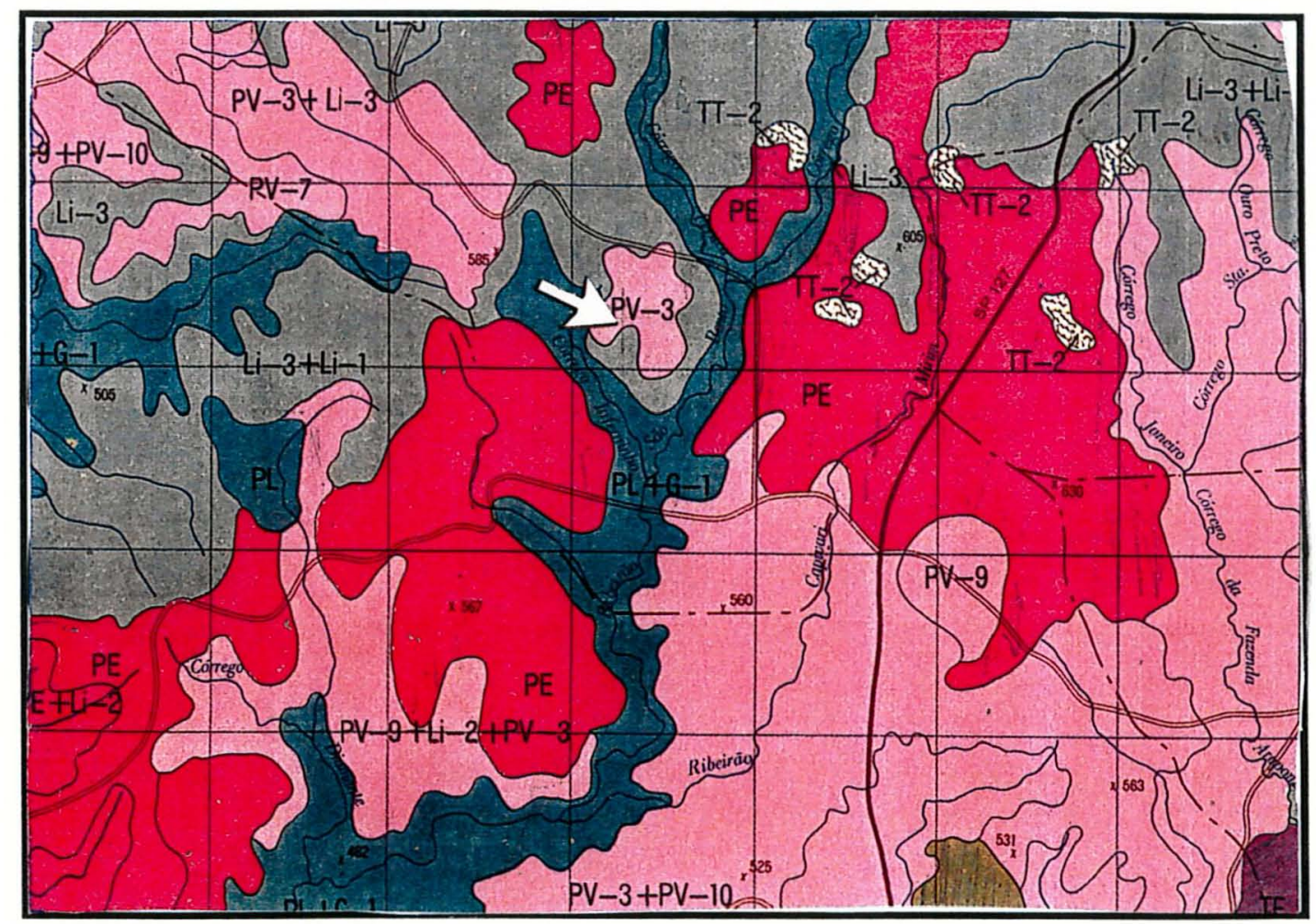

Figura 10 - A toposseqüência estudada esta associada a Podzólicos Vermelho Amarelo (PV3).pela carta de Oliveira \& Prado (1989) na escala 1:100.000. Em branco (TT-2) extração de calcário e na seta branca a localização da depressão estudada. 


\subsubsection{Pedoclima}

Os solos da região possuem regime hipertérmico (Oliveira et al., 1976), caracterizados por apresentar a temperatura média do solo superior a $22^{\circ} \mathrm{C}$ e amplitude entre a média da temperatura dos meses de verão e dos meses de inverno superior a $5{ }^{\circ} \mathrm{C}$.

O regime hídrico dos solos da região é údico, caracterizado por apresentar menos de 90 dias consecutivos de deficiência hídrica (Oliveira et al., 1976).

\subsection{Métodos}

Procurou-se reconhecer detalhadamente as diferentes organizações existentes. Para tanto, foram realizadas análises morfológicas (macro e micro) em topossequiência, de modo a representar as organizações dos solos em cortes bidimensionais.

Com o auxilio do teodolito, determinaram-se as deformações e oscilações no nível de base dos sedimentos da Formação Irati em pedreiras próximas e a planialtimetria da toposseqüência.

As análises micromorfológicas serviram de apoio ao estudo morfológico de campo e foi acompanhado, ainda, de análises granulométricas, químicas (complexo sortivo e ataque sulfúrico) e mineralógicas.

\subsubsection{Análises macromorfológicas}

As descrições foram realizadas conforme Lemos \& Santos (1984).

\subsubsection{Análises granulométricas}

As análises granulométricas foram realizadas através do método do densímetro, utilizando-se como dispersante o hidróxido de sódio e o hexametafosfato de sódio, com as frações areia separadas por peneiramento nas frações areia muito fina, areia fina, areia média, areia grossa e areia muito grossa (Camargo et al. 1986). 


\subsubsection{Análises químicas do complexo sortivo}

Segundo Raij et al. (1987), foram analisados: pH em água, matéria orgânica, $\mathrm{Ca}^{++}, \mathrm{Mg}^{++}, \mathrm{K}^{+}, \mathrm{Al}^{+++}$e $\mathrm{H}^{+}+\mathrm{Al}^{+++}$. A determinação da matéria orgânica foi realizada colorimetricamente; $0 \mathrm{Ca}^{++}$e $\quad$ o $\mathrm{Mg}^{++}$foram determinados por espectrofotometria de absorção atômica; o $\mathrm{K}^{+}$por fotometria de chama de emissão e o $\mathrm{H}^{+}+\mathrm{Al}^{+++}$por titulação.

\subsubsection{Ataque sulfúrico}

A partir do ataque sulfúrico (Camargo el al., 1986), determinou-se o $\mathrm{SiO}_{2}$, $\mathrm{Al}_{2} \mathrm{O}_{3}, \mathrm{TiO}, \mathrm{Fe}_{2} \mathrm{O}_{3}$ e $\mathrm{MnO}$. A determinação do $\mathrm{SiO}_{2}$ foi realizada por gravimetria, $\mathrm{Al}_{2} \mathrm{O}_{3}$ por titulação, $\mathrm{TiO}_{2}$ por colorimetria e $\mathrm{Fe}_{2} \mathrm{O}_{3}$ e $\mathrm{MnO}$ por espectrofotometria de absorção atômica.

\subsubsection{Mineralogia da fração argila}

As análises mineralógicas das frações argila e silte foram realizadas por difratometria de raios-X.

Inicialmente foram eliminados os sais solúveis, a matéria orgânica e os óxidos de ferro, conforme propõe Jackson (1969). Os sais solúveis foram removidos com uma solução de acetato de sódio a $\mathrm{pH} 5$, a matéria orgânica por oxidação posterior com peróxido de hidrogênio a $30 \%$ e lavagem novamente com solução de acetato de sódio a $\mathrm{pH} 5$.

Em amostras livre de sais e matéria orgânica removeram-se os óxidos de ferro livre pela adição de citrato de sódio $0,3 \mathrm{M}$, bicarbonato de sódio $1 \mathrm{M}$, ditionito de sódio e finalmente, adicionou-se uma solução de $\mathrm{NaCl} 1 \mathrm{~N}$ para promover a floculação dos colóides. Repetiu-se toda a operação até a amostra apresentar-se branca ou cinza.

Em seguida a fração argila $(<0,2 \mu \mathrm{m})$ foi separada por sifonação e saturada com $\mathrm{K}^{+}$e $\mathrm{Mg}^{++}$. Subamostras foram irradiadas com raios-X através de difratômetro Rigaku, com tubo de cobre e filtro de níquel, no intervalo $2 \theta$ de $3^{\circ}$ a $30^{\circ}$. 
Subamostras saturadas com $\mathrm{K}^{+}$e $\mathrm{Mg}^{++}$foram submetidas, respectivamente, a aquecimentos de $110^{\circ} \mathrm{C}$ e $550^{\circ} \mathrm{C}$ e solvatadas com etileno-glicol e posteriomente irradiadas.

Os minerais da fração argila foram identificados baseados nos espaçamentos basais e suas alterações segundo os tratamentos realizados, segundo Brindley \& Brown (1980). A mica pelo espaçamento basal de aproximadamente $5 \AA$ e 10 $\AA$, que não se alteram com os tratamentos; a haloisita por seus picos a 7,2-7,5 $\AA$ que desaparecem com aquecimento a $550^{\circ} \mathrm{C}$; a vermiculita pelo pico a aproximadamente 14 $15 \AA$ com os tratamentos de argila saturada com $\mathrm{Mg}^{++}$e $\mathrm{Mg}^{++}$solvatada com etileno glicol, que se contrai a aproximadamente $10 \AA$ com os outros tratamentos, a não contração com a saturação com $\mathrm{K}^{+}$a $25^{\circ} \mathrm{C}$, indica vermiculita com intercamada de hidróxido de alumínio; a esmectita pelo espaçamento basal em torno de $17 \AA$ com $\mathrm{Mg}^{++}$ solvatado com etileno glicol, que se contrai a: $14 \AA$ com $\mathrm{Mg}^{++}$, aproximadamente $12,5 \AA$ com $\mathrm{K}^{+} 25{ }^{\circ} \mathrm{C}$ e aproximadamente $10 \AA$ com $\mathrm{K}^{+}$a 350 e $550{ }^{\circ} \mathrm{C}$; a clorita pelo espaçamento próximo de $14 \AA$ que não se altera com nenhum tratamento. Interestratificados foram identificados pelo método de MÉRIMG (1949), com espaçamentos dos argilominerais constituintes somados e seus possíveis submúltiplos com mica/clorita $24-26 \AA$ e $12-13 \AA$ em todos os tratamentos; mica/vermiculita pelo espaçamento intermediário entre 10 e $14 \AA$ se contrai a $10 \AA$ com $\mathrm{K}^{+} 25^{\circ} \mathrm{C}$, podendo ter picos da soma dos dois argilominerais constituintes, segundo os respectivos tratamentos.

O silte foi analisados na forma de pó, no intervalo $2 \theta$ de $2^{\circ}$ a $60^{\circ}$.

A identificação dos minerais da fração silte e foi realizada através dos espaçamentos basais segundo Brindley \& Brown (1980). 


\subsubsection{Microscopia ótica}

\subsubsection{Preparação das amostras}

No preparo das amostras foram confeccionadas lâminas delgadas a partir de materiais indeformados, previamente impregnados com uma mistura à base de resina cristal T 208 (fabricante Difibra), monômero de estireno (diluente) e Luperox como catalizador. A proporção foi de $50 \%$ de resina, $50 \%$ de diluente e 3 gotas de catalizador para cada $500 \mathrm{ml}$ da mistura, conforme metodologia adaptada de Castro (1985).

\subsubsection{Método utilizado na descrição micromorfológica}

Procurou se reconhecer os constituintes e sua ocorrência, mediante estatística elementar (contagem, distribuição, tamanho, teores relativos e outros), os arranjos, a tipologia, a natureza, a hierarquia e a cronologia entre as diferentes organizações, segundo os critérios de descrição e observação estabelecidos por Brewer (1976) e Stoops \& Jongerius (1975).

O estudo micromorfológico acompanhou a evolução vertical das organizações pedológicas no perfil e depois na toposseqüência. Os aumentos foram progressivos, até serem selecionados campos e sítios representativos para a caracterização detalhada das organizações presentes.

\subsubsection{Os passos metodológicos}

-Através de mapas e visitas a campo escolheu-se uma depressão significativa da região, próxima a pedreiras de exploração de calcário, em três faces que margeiam a depressão (nordeste a leste, oeste e noroeste) com exposições geológicas de até 30 metros de altura e mais de $2 \mathrm{Km}$ de comprimento, somadas as diferentes pedreiras. O banco de calcário da base é o responsável por prováveis formações de dolinas, sendo mapeado na maior parte das exposições geológicas;

-Descrição dos solos com a abertura de 4 trincheiras $(1 \times 1,5$ por 2 de profundidade) para a análise mais detalhada em toposseqüência, da porção mais baixa á 
porção mais alta, respeitando-se a diferenciação pedológica superficial (cor) e em direção a exposição de calcário no topo, sob a cobertura pedológica. Esta descoberta foi acompanhada de descrição morfológica, coleta de amostras para análises granulométricas e químicas e coleta de amostras indeformadas para análise micromorfológica;

-Análises químicas, granulométricas, micromorfológicas e mineralógicas;

-Volta ao campo com novas informações que direcionaram as observações em perfis e coleta de amostras indeformadas;

•Observação mais detalhada dos solos da região e outras depressões na região com a retirada da cana-de-açúcar;

-Descrição da diferenciação lateral entre trincheiras, com tradagens;

-Observação mais detalhada das exposições geológicas em duas pedreiras próximas da depressão, acompanhando o padrão de alteração e expansão dos sedimentos e alteritas, com determinação pelo de levantamento taquiométrico (com teodolito), em exposições mais recentes, das diferentes taxas de "mergulho" dos sedimentos da Formação Irati e Formação Corumbataí e diferenças na expansão dos sedimentos consolidados e alteritas mais solos;

-Aprofundamento das trincheiras até $2,40 \mathrm{~m}$, com mapeamento de lâminas milimétricas, e leitos centimétricos de sílex nas trincheiras;

-Término das observações micromorfológicas;

-Síntese das observações e análises. 


\subsection{Organização da cobertura pedológica}

Na figura 11, o perfil 1 é classificado como Podzólico Vermelho Escuro, Tb, A chernozêmico, argilosa/muito argilosa; o perfil 2 como Podzólico Vermelho Amarelo, Tb, A moderado endoeutrófico, argilosa /muito argilosa; o perfil 3 como Podzólico Vermelho Amarelo gleico, Tb, A chernozêmico, média/argilosa

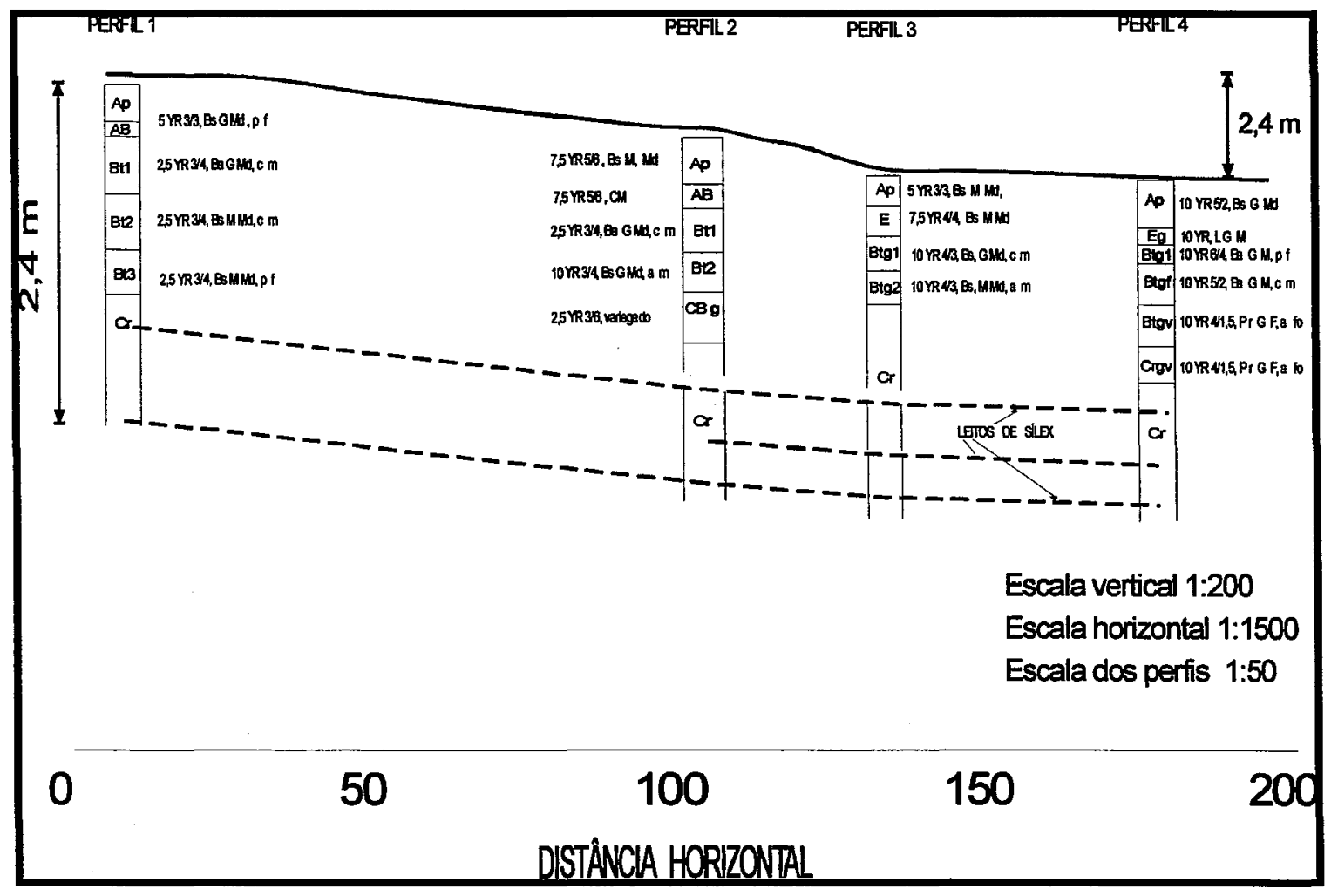

Figura 11 - Estrutura: grau: $\mathrm{Fr}=$ fraca, $\mathrm{Md}=$ moderada, $\mathrm{Fo}=$ forte; classe: $\mathrm{P}=$ pequena, $\mathrm{M}=$ média, $\mathrm{G}=$ grande; Tipo: $\mathrm{Bs}=$ blocos subangulares, $\mathrm{Ba}=$ blocos angulares, $\mathrm{Pr}=$ prismático, $\mathrm{L}=$ laminar. Cerosidade: quantidade: $\mathrm{p}=$ pouco, $\mathrm{c}=$ comum, $\mathrm{A}$ abundante. 
e o perfil 4 como Hidromórfico Cinzento álico gleico plíntico vértico, $\mathrm{Ta}, \mathrm{A}$ moderado endoeutrófico, argilosa/muito argilosa.

Nos perfis 3 e 4 no pico da estação seca o lençol freático chegou a $1,40 \mathrm{~m}$ da superficie e nos meses de dezembro a fevereiro houve o afloramento de água, Nesta mesma época no perfil 2 a água atingiu até 1 metro da superfície, porém a drenagem da água foi mais rápida que nos perfis 3 e 4 . $O$ perfil 1 possui excelente drenagem.

Os perfis apresentam concreções de sílex litoherdadas ("bonecas de sílex") e plaquetas de sílex, típicas dos solos desenvolvidos sobre os sedimentos da Formação Irati, porém no perfil 4 há uma redução significativa das "bonecas" e das plaquetas de sílex.

A cobertura pedológica possui uma diferenciação lateral mais rápida no meio hidromófico (perfis 2, 3 e 4), seguindo com uma variação difusa até o primeiro perfil.

Os volumes de alteritas serão apresentados junto com todos os perfis, sendo discutidos em conjunto.

\subsubsection{Perfil 1}

No perfil 1 (figuras 12 e 13), fora do meio hidromórfico, foram identificados, basicamente, 3 horizontes concordantes com o relevo e 8 volumes de alteração muito ondulados. 
Figura 12 - Perfil 1 no topo da toposseqüência em meio bem drenado, nota-se uma concentração de pontos brancos a partir de aproximadamene $90 \mathrm{~cm}$ de profundidade (seta branca) até os volumes de alteração, que são as bonecas e plaquetas de sílex litoreliquíais do material de origem.
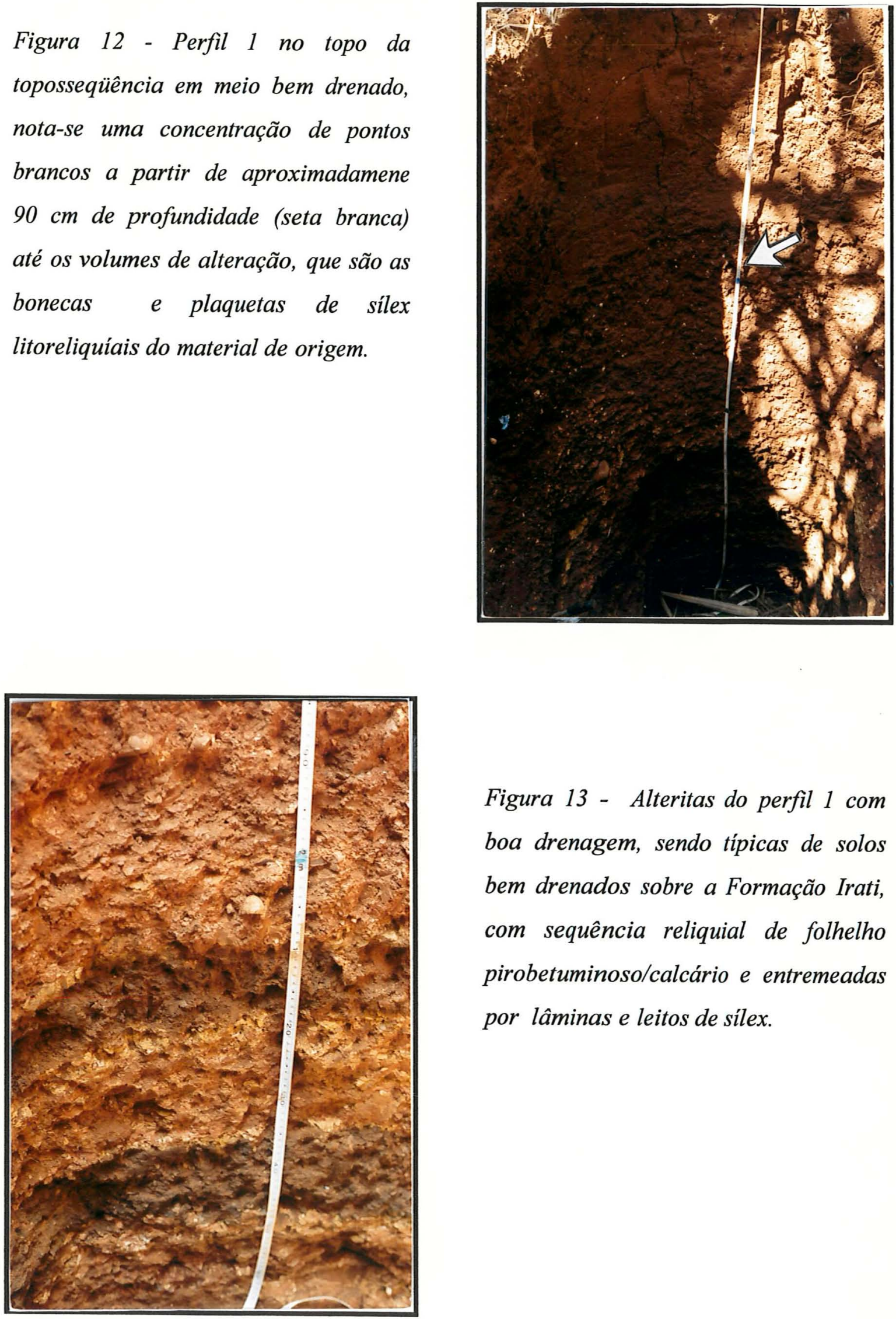

Figura 13 - Alteritas do perfil $1 \mathrm{com}$ boa drenagem, sendo típicas de solos bem drenados sobre a Formação Irati, com sequência reliquial de folhelho pirobetuminoso/calcário e entremeadas por lâminas e leitos de silex. 
O primeiro horizonte, indo até $39 \mathrm{~cm}$ de profundidade, possui estrutura mais compactada, de cor bruno avermelhado escuro (5 YR 3/3); argiloso; fragmenta-se em blocos subangulares de tamanho médio e grau moderado, que se desfazem em blocos moderados e pequenos; duro, friável, plástico e pegajoso; possui uma transição difusa (10 $\mathrm{cm})$ e plana. $\mathrm{O}$ volume pedológico de transição diferencia-se pela presença de cerosidade descontínua, fraca, pouca e é o horizonte mais compactado do horizonte Ap. A porosidade é tubular milimétricas (com freqüência de $1 \mathrm{poro} / \mathrm{cm}^{2}$ )e fissura horizontal centimétrica nos primeiros centímetros.

O segundo horizonte, de 39 a $80 \mathrm{~cm}$ de espessura, de cor bruno avermelhado escuro (2,5 YR 3/4); argiloso; fragmenta-se em blocos subangulares médios moderados a blocos angulares moderados e grandes; duro, firme, mais plástico e pegajoso que horizonte anterior; com transição difusa, horizontal e plana. A cerosidade é contínua, comum e moderada.

O terceiro horizonte, de 80 a $145 \mathrm{~cm}$ de espessura, de cor bruno avermelhada escura (2,5 YR 3/4); argiloso; fragmenta-se em blocos subangulares médios, moderados; duro, firme, plástico e pegajoso; a transição é difusa, ondulada e inclinada, com base (de 10 a $20 \mathrm{~cm}$ ) de concentração de bonecas e plaquetas de sílex. A cerosidade é comum e moderada, passando a pouca e fraca. Poros fissurais delimitam as bonecas e plaquetas.

\subsubsection{Perfil 2}

Está na transição do fim do domínio hidromórfico para o domínio bem drenado, possuindo 4 volumes pedológicos e 8 volumes de alteritas (figuras 14 e 15). A seguir são descritos os 4 volumes pedológicos. 
Figura 14 - Perfil 2 na transição para o meio hidromórfico, pontos brancos a aproximadamente um 1,00 metro (seta branca) são bonecas e plaquetas de silex de modo semelhante ao perfil 1.
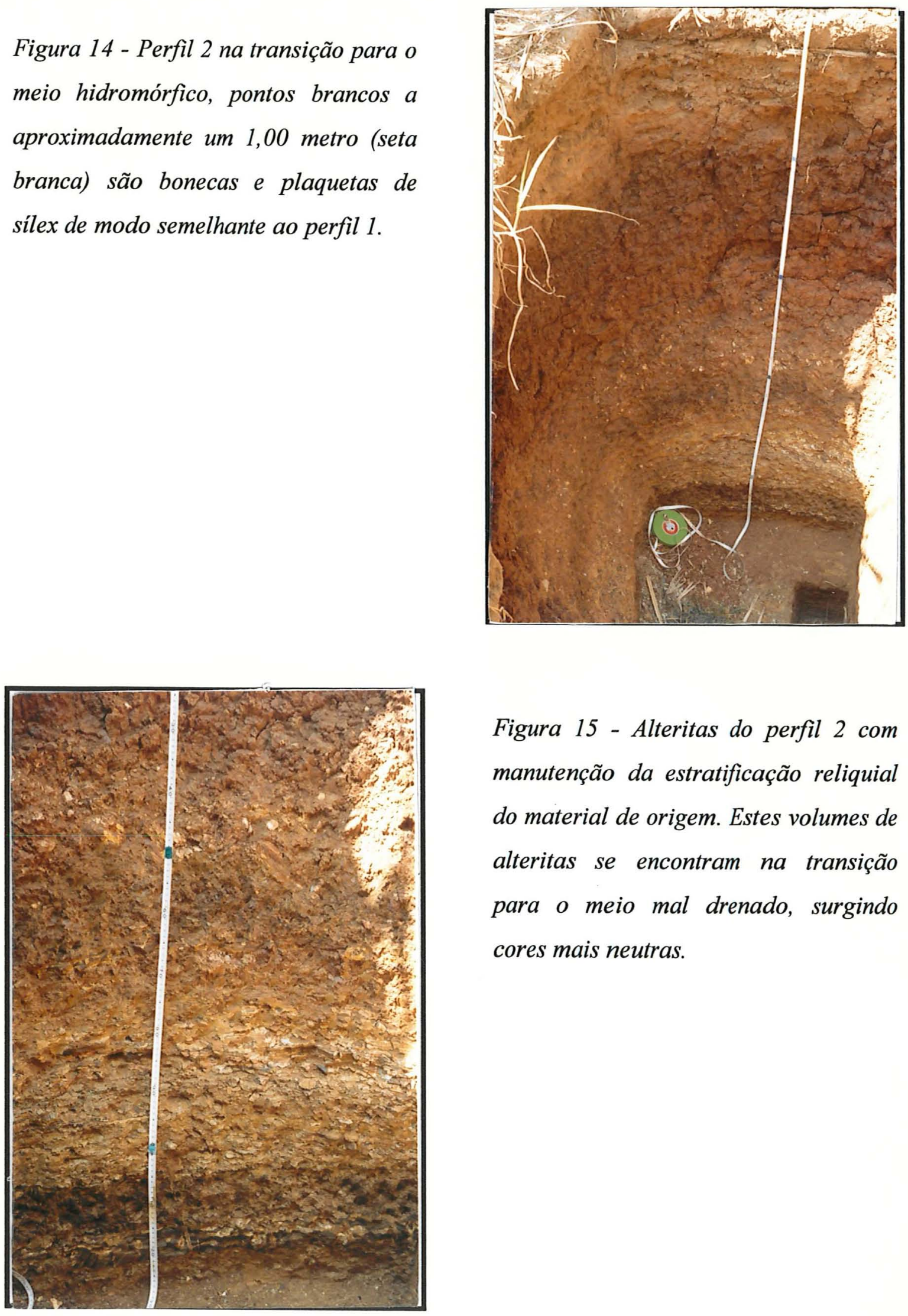

Figura 15 - Alteritas do perfil 2 com manutenção da estratificação reliquial do material de origem. Estes volumes de alteritas se encontram na transição para o meio mal drenado, surgindo cores mais neutras. 
O primeiro horizonte, de até $25 \mathrm{~cm}$ de profundidade, bruno forte $(7,5 \mathrm{YR}$ 5/6); argiloso; fragmenta-se em blocos médios moderados; duro, firme, plástico e pegajoso; com transição gradual plana e horizontal. A porosidade milimétrica $\left(1 \mathrm{~cm}^{2}\right)$ é tubular.

O segundo horizonte, de 25 a $42 \mathrm{~cm}$, bruno forte (7,5 YR 5/6); argiloso; de aparência compacta maciça, se fragmenta em lâminas de 8 a $10 \mathrm{~cm}$; plástico e pegajoso; com transição difusa plana e horizontal.

O terceiro horizonte, de 42 a $75 \mathrm{~cm}$, bruno avermelhado escuro (2,5 YR 3/4); argiloso; fragmenta-se em blocos angulares grandes e moderados; ligeiramente duro, friável, plástico e pegajoso; com transição plana, horizontal e gradual. A cerosidade presente é contínua e moderada, com porosidade tubular milimétrica e surgimento de poros fissurais delimitando agregados.

O quarto horizonte, de 75 a $105 \mathrm{~cm}$, vermelho escuro acinzentado (10 R 3/4); argiloso; fragmenta-se em blocos subangulares grandes e moderado; ligeiramente duro, firme, plástico e pegajoso; com transição gradual, plana e horizontal. A cerosidade é contínua moderada e abundante, mais contrastante que o horizonte anterior em relação ao fundo matricial. Os poros são tubulares milimétricas $\left(2\right.$ a $\left.3 \mathrm{~mm}^{2}\right)$ e envolvendo as litorelíqueas existem poros fissurais (bonecas e plaquetas). É o horizonte de concentração de bonecas e plaquetas.

O quinto volume é um horizonte de transição com os volumes de alteração, de 105 a $140 \mathrm{~cm}$, vermelho escuro (2,5 YR 3/6) com manchas variegadas em avermelhado e esverdeado, azulado.

O quarto e quinto horizontes se situam na faixa de oscilação do lençol.

\subsubsection{Perfil 3}

Situa-se dentro do domínio hidromórfico, com o surgimento de cores mais neutras e feições ferruginosas (mosqueados e plintitas). Possui 4 volumes pedológicos, um de transição para volumes de alteração e 8 volumes de alteração (figuras 16 e 17). 
Figura 16 - Perfil 3 dentro do meio hidromórfico na transição para o centro da depressão. As "bonecas" de silex apresentam uma distribuição mais caótica em relação aos perfis anteriores, porém ainda reduzem em número em direção a superficie como nos perfis anteriores.
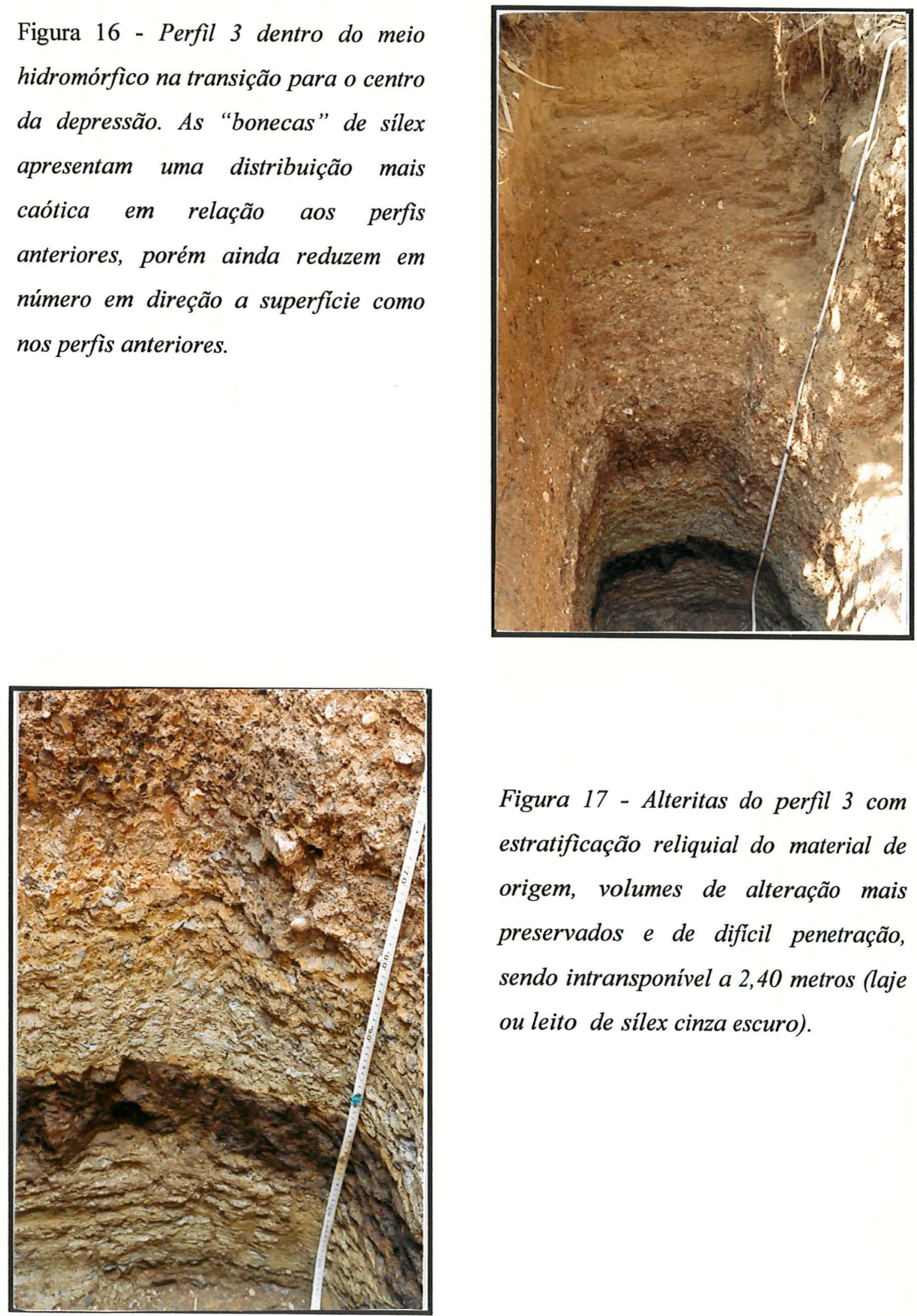

Figura 17 - Alteritas do perfil 3 com estratificação reliquial do material de origem, volumes de alteração mais preservados e de dificil penetração, sendo intransponivel a 2,40 metros (laje ou leito de sílex cinza escuro). 
O primeiro horizonte indo até $20 \mathrm{~cm}$, bruno avermelhado escuro (5 YR 3/3); argiloso; fragmenta-se em blocos subangulares médios e fracos; macio, friável, plástico e pegajoso; com base de transição clara, horizontal e plana, com cor ligeiramente mais intensa (5 YR 3/4) e surgimento de mosqueamento vermelho amarelado (5 YR 4/6).

O segundo horizonte, de 20 a $43 \mathrm{~cm}$, bruno escuro (7,5 YR 4/4); argiloso; fragmenta-se em blocos subangulares médios a pequenos e moderado; duro, firme, plástico e pegajoso; a transição é gradual ondulada com ligeira mudança de intensidade de cor (7,5 YR 4/6). Mosqueamento vermelho escuro (2,5 YR 3/6) em quantidade semelhante à base do horizonte anterior, horizontes mais seco que anterior e mais compacto.

O terceiro horizonte, de 43-92 cm, bruno escuro amarelado (10 YR 4/3); argiloso; blocos subangulares grandes a médios moderados na porção superior e média para pequenos na base; ligeiramente duro, firme, plástico e pegajoso; transição plana, horizontal e clara. A cerosidade comum e moderada torna-se abundante na porção inferior. Início de gleização, mosqueado vermelho escuro $30 \%$ e plintita $5 \%$ no topo, que aumenta para $40 \%$ de mosqueado e $10 \%$ de plintita.

O $4^{\circ}$ horizonte é de transição com os volumes de alteração, de 92 a 120 $\mathrm{cm}$, variegado com avermelhado e preto.

A maior oscilação do lençol freático ocorre nos horizontes 2 e 3.

\subsubsection{Perfil 4}

Trincheira situada na base da depressão, em perfil mais profundo e com maior diferenciação vertical que os anteriores.

Existem 7 volumes pedológicos com transições de graduais a difusas e concordantes com o relevo, com exceção do horizonte $\mathrm{E}$ álbico com limites muito irregulares e quebrados (figuras .19 e 20). 
Figura 18 - Perfil 4 no centro do meio hidromórfico, com quase desaparecimento das bonecas $e$ plaquetas, surgimento de diferenciação pedológica vertical mais contrastante.

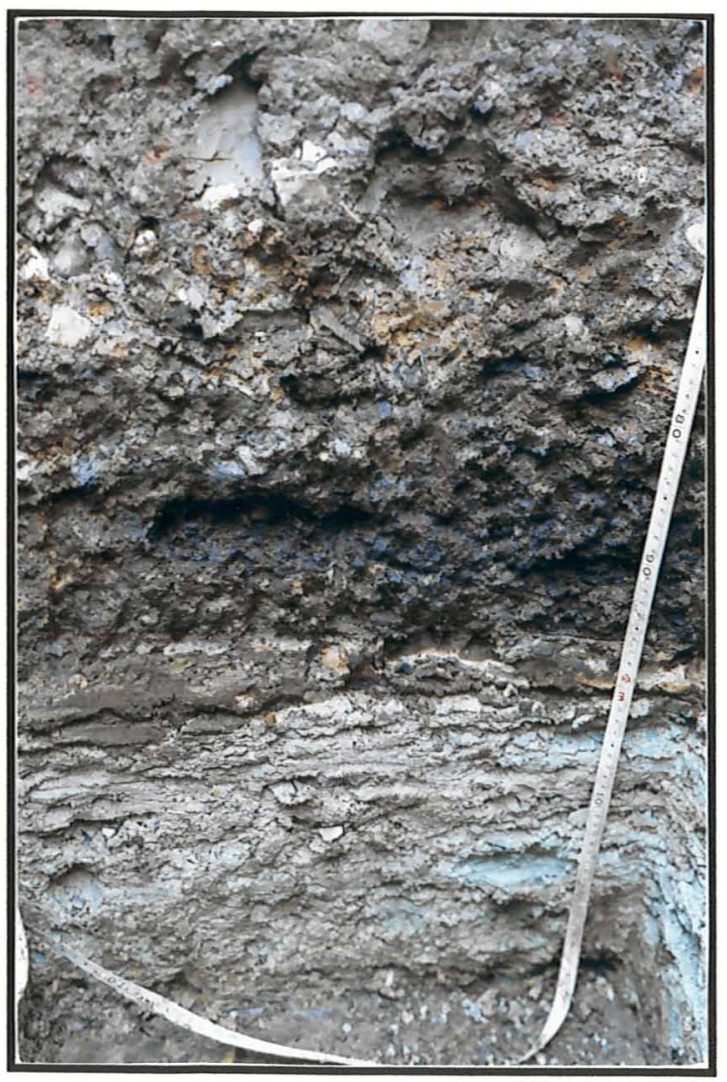

Figura 19 - Alteritas do perfil 4 com acentuamento dos matizes esverdeados e maior dificuldade para a penetração com vanga ou picareta, com laje de sílex cinza escura intransponível a 2,40 $m$. 
O primeiro horizonte, de 0 a $35 \mathrm{~cm}$, bruno acinzentado (10 YR 5/2); argiloso; que se fragmenta em blocos subangulares grandes e moderados $(20-50 \mathrm{~cm})$; ligeiramente duro, firme, plástico e pegajoso; transição abrupta, ondulada e horizontal. Porosidade tubular com distribuição irregular, submilimétrica a milimétrica, com aproximadamente 5 por $\mathrm{mm}^{2}$, associada à atividade de formigas e porosidade fissural horizontal nos primeiros $2 \mathrm{~cm}$ superficiais. Mosqueados de cor vermelho amarelado (5 YR 4/6). Poucas raízes milimétricas.

O segundo horizonte, de 35 a $48 \mathrm{~cm}$ variando de 40 a $78 \mathrm{~cm}$ na base; amarelo brunado (10 YR 6/4); argilo-siltoso; que se fragmenta em lâminas grandes e moderadas; ligeiramente duro, ligeiramente firme, plástico e pegajoso. A transição é irregular e quebrada; plana e abrupta. Mosqueados vermelho amarelado (5 YR 4/6) em fundo cinza brunado claro (10 YR 6/2) e menos frequentemente vermelho amarelado (5 YR 4/6). Porosidade semelhante ao horizonte anterior, sem poros fissurais. Raizes milimétricas menos abundantes que anterior.

O terceiro horizonte, de 48 a $60 \mathrm{~cm}$, amarelo brunado (10 YR 6/4); argiloso; que fragmenta-se blocos angulares grandes e moderados; duro, ligeiramente, plástico e pegajoso; transição ondulada e quebrada, variando de 52 a $69 \mathrm{~cm}$. Cerosidade contínua, fraca e pouca. Porosidade semelhante a ao horizonte anterior com raízes milimétricas mais abundantes. Mosqueados vermelho amarelado (5 YR 4/6), mais abundantes que Ega, relíqueas do Btg dentro deste horizonte.

O quarto horizonte, de 60 a 90, bruno acinzentado (10 YR 5/2), argiloso; fragmenta-se em blocos angulares grandes e moderados; duro, firme, muito plástico e pegajoso; transição plana, horizontal e difusa. $(15 \mathrm{~cm})$. Cerosidade contínua, comum e abundante. Mosqueados com aumento dos domínios avermelhados sobre fundo mais cinza, com mais de $15 \%$ dos mosqueados suficientemente individualizados para serem considerados plintitas. Porosidade tubular milimétrica $\left(3\right.$ por $\left.\mathrm{cm}^{2}\right)$ raízes milimétricas mais grossas e menos abundantes que horizonte anterior.

O quinto horizonte, de 90 a 120, cinza (10 YR 5/1,5); argiloso; se fragmenta blocos angulares tendendo a prismáticos grandes e forte; muito duro, muito 
firme, muito plástico e pegajoso; transição plana horizontal e difusa $(15 \mathrm{~cm})$. Mosqueados semelhantes ao horizonte anterior, superficies de estriamento mais visíveis (solo muito úmido). Cerosidade contínua, forte e abundante. Porosidade semelhante e raízes menos abundantes que o horizonte anterior. Superficies de estriamento visíveis.

O sexto horizonte, de 120 a 147, cinza escuro (10 YR 4/1,5); muito argiloso; fragmenta-se em prismas grandes de grau forte de desenvolvimento, (70-80 $\mathrm{mm}$ ); muito duro, muito firme, muito plástico e pegajoso; transição plana, horizontal e gradual $(10 \mathrm{~cm})$. Cerosidade contínua, forte e abundante. Superficies de estriamento mais visíveis que horizonte anterior. Porosidade tubular submilimétrica com até 3 por $\mathrm{cm}^{2}$. Raízes raras. Fundo mais cinza, com surgimento de domínios amarelados junto com mosqueamento avermelhados, possivelmente de degradação da plintita.

O sétimo horizonte, de transição em solo e alteritas, de 147 a 165, mais argiloso de todos os horizontes, domínios acinzentados azulados $(60 \%)$, com raízes esmagadas, domínios amarelados, com $20 \%$ da massa de solo, pontos avermelhados no centro dos domínios amarelados indicando possível degradação da plintita (mais que 15\% da massa de solo).

\subsubsection{Análises granulométricas}

As frações areia fina e muito fina constituem de 70 a $80 \%$ da areia dos horizontes $\mathrm{A}$ e de 60 a $70 \%$ da areia dos horizontes $\mathrm{B}$. Conforme a figura 20 , não existem tendências em relação à fração argila e silte em direção a jusante nos perfis $1,2 \mathrm{e}$ 3. Os horizontes A possuem, em média, $34 \%$ de silte nos perfis 1, 2 e 3, enquanto os horizontes $B$ de todos os perfis possuem média de $25 \%$. No perfil 4 , há uma redução de mais de 50 \% na fração areia, acompanhado pela redução nas frações de areia fina e areia muito fina, com aumento da fração silte (44 \%), e em menor grau o aumento da fração argila. A observação micromorfológica (Figuras 21 até 43) dos perfis 1, 2 e 3 mostrou os grãos de areia fina e areia muito fina iniciando um processo de fissuração em grãos de silte. No perfil 4 o hidromorfismo mais intenso individualizou quase completamente os grãos de silte. 


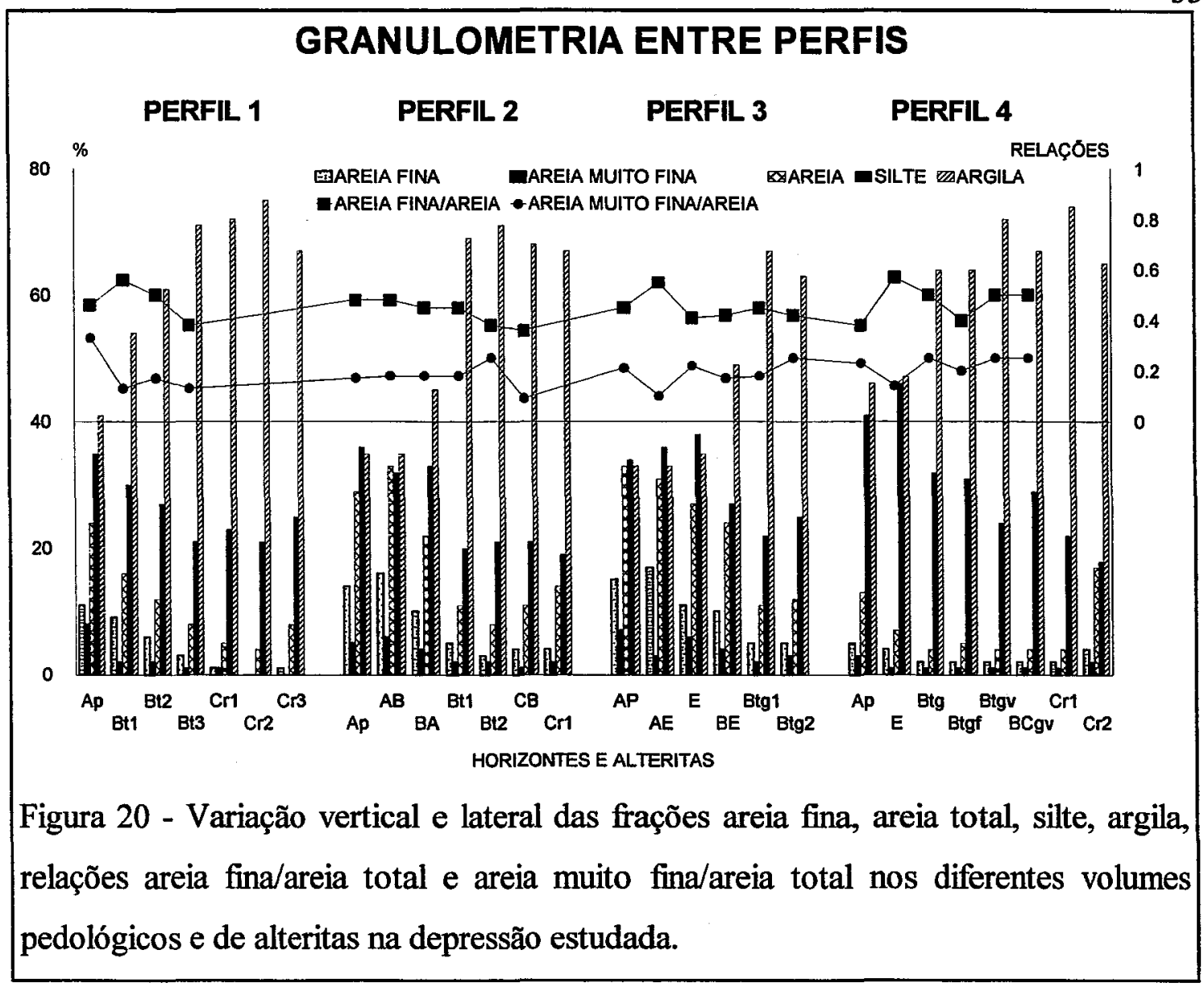

Segundo Amaral (1971), o silte e areia constituem menos de $5 \%$ do total das rochas calcárias, mineralogicamente predominando o quartzo e os feldspatos. A presença da areia total nos perfis estudados aumenta de $5 \%$ até $33 \%$ em direção a superficie e é acompanhado pela redução em número e tamanho das litorelíqueas ("bonecas" e plaquetas de silex). Portanto, a areia nos solos é predominantemente proveniente destas litorelíqueas, que possuem pirita finamente dividida em sua constituição, fato observado nas pedreiras, nos solos e análise mineralógica. A hidromorfia, solubilizando o ferro, provavelmente auxilia a degradação da fração areia em silte. Delvigne (1983) relata que as litorelíqueas podem persistir nos horizontes superficiais se seu tamanho e composição assim permitirem, com os fenômenos de solubilização e fraturamento reduzindo os grãos de cascalho e areia a silte grosseiro. 


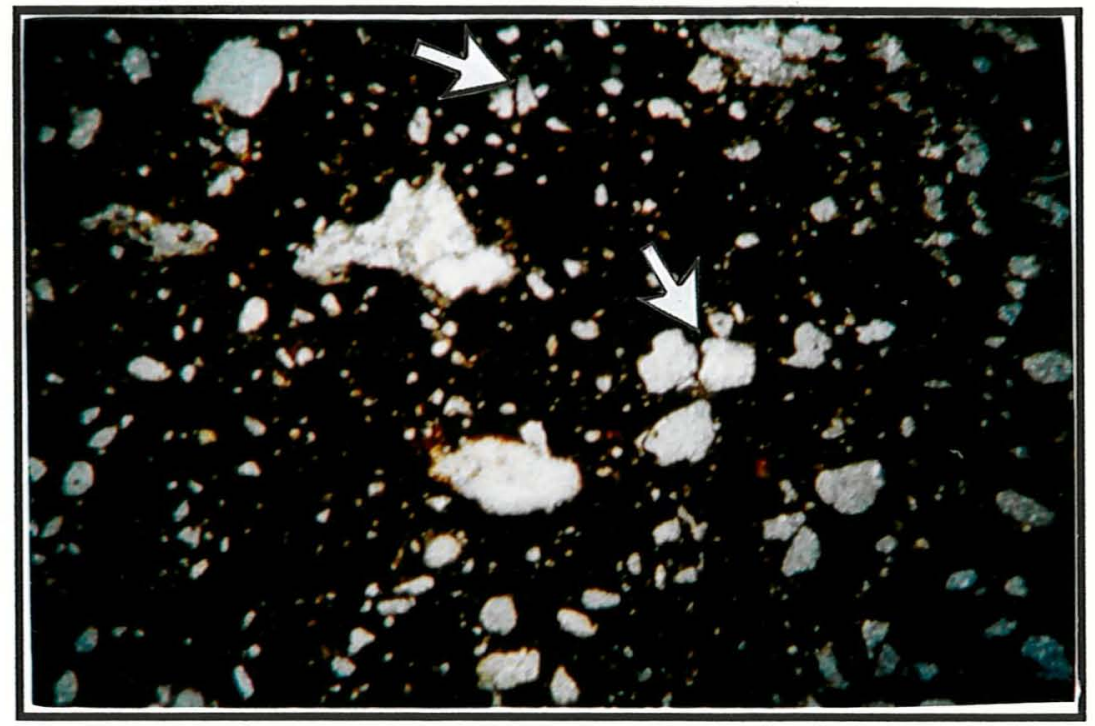

Figura 21 - Fotomicrografia de campo representativo do perfil 1 (Ap/Bt1, 29-39 centímetros), aumento de 25 vezes, luz normal, com exemplos de grãos de esqueleto de quartzo da dimensão de areia média se fragmentando em grãos de tamanho areia muito fina (seta branca) no centro e areia muito fina se fragmentando em silte em cima (seta branca).

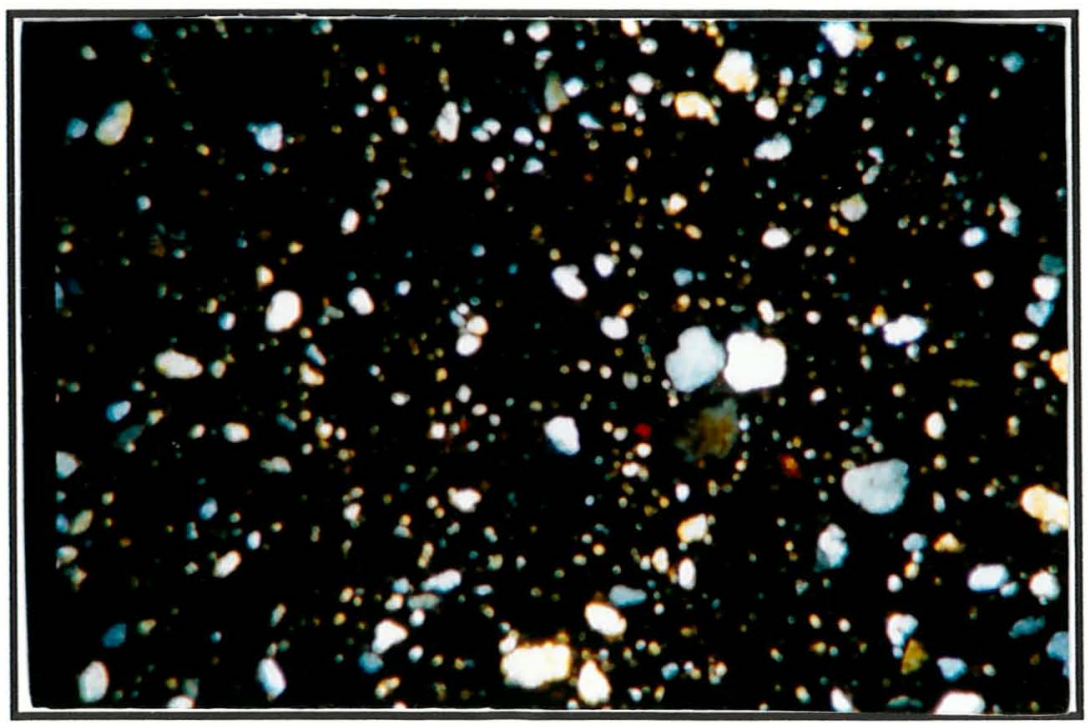

Figura 22 - Idem figura anterior com luz polarizada, grãos de quartzo de cinza a branco. 


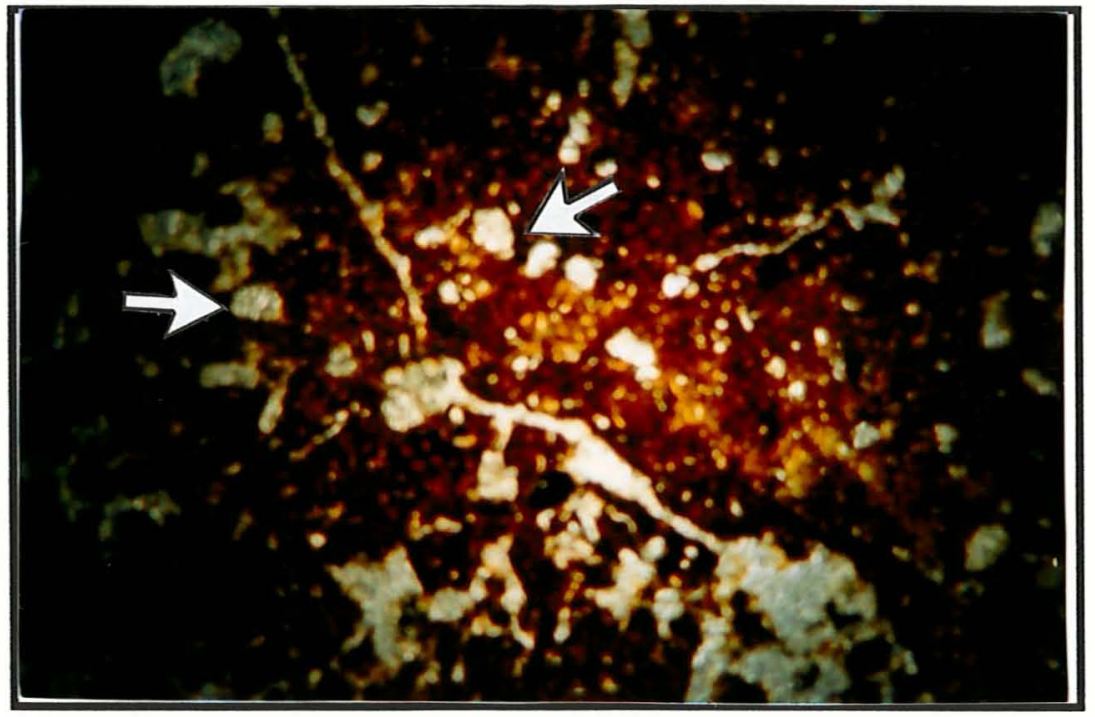

Figura 23 - Fotomicrografia de campo representativo do perfil 1 (Bt2/Bt3 75-85 centímetros), aumento de 25 vezes, luz normal, com exemplos de grãos de esqueleto de quartzo da dimensão de areia fina iniciando fissuração em grãos de tamanho silte. (seta branca).

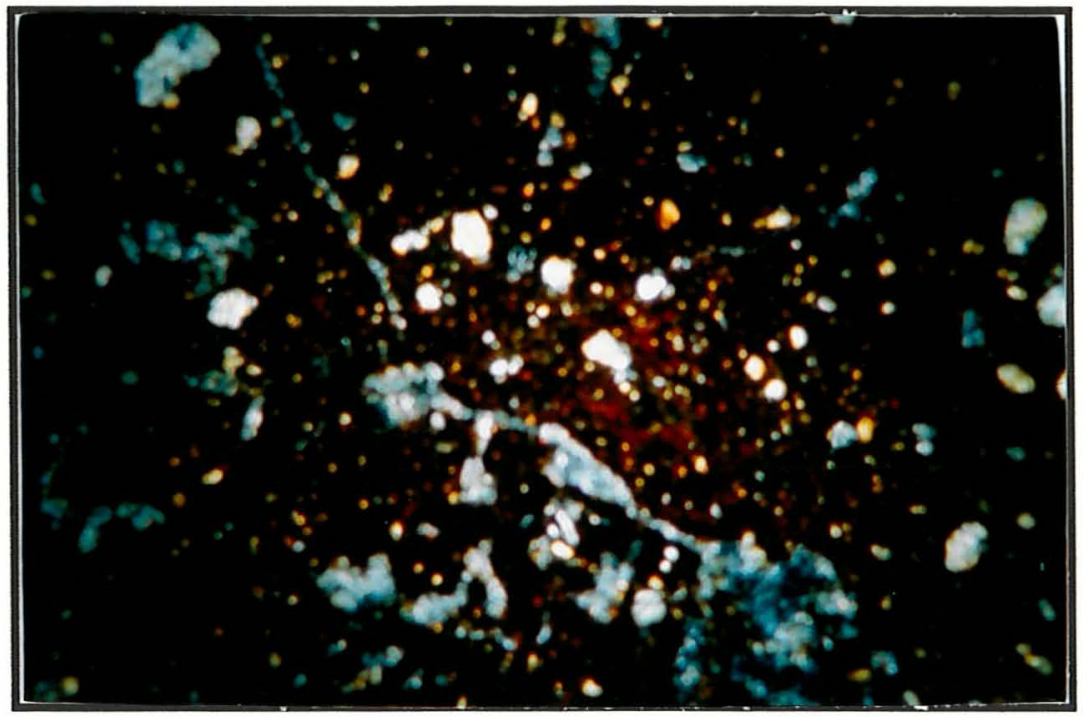

Figura 24 - Idem figura anterior com luz polarizada, porosidade dominante câmeras e canais e secundariamente fissurais. 


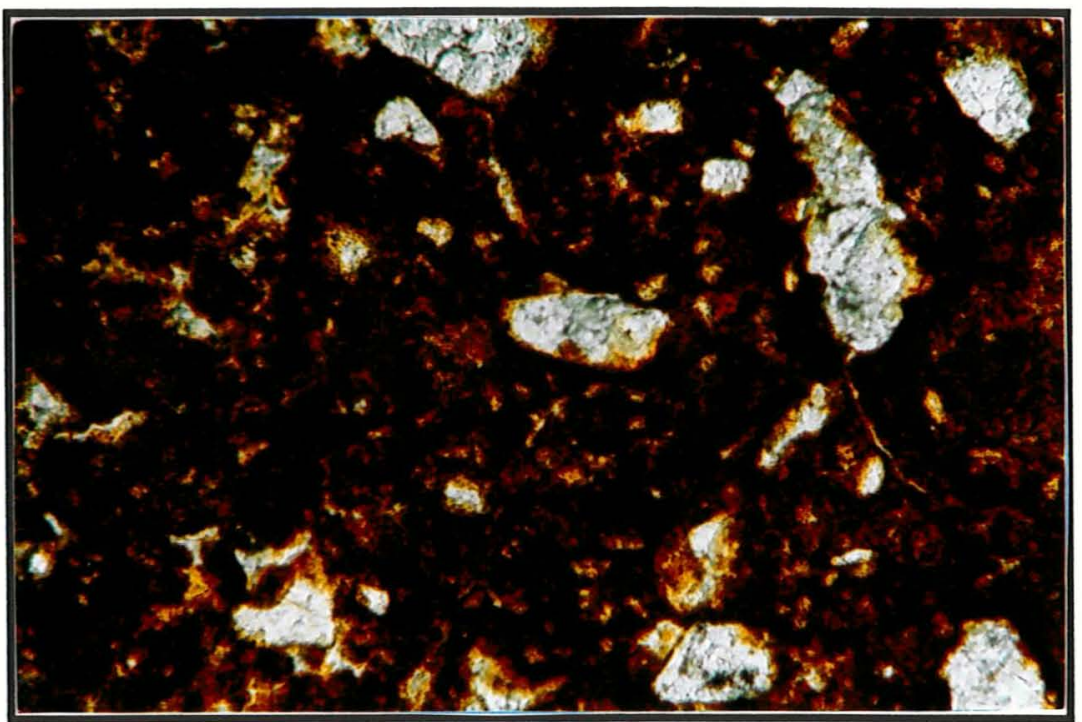

Figura 25 - Fotomicrografia de campo representativo do perfil 1 (Bt2/Bt3 75-85 centímetros), aumento de 100 vezes, luz normal, plasma massépico e bimassépico.

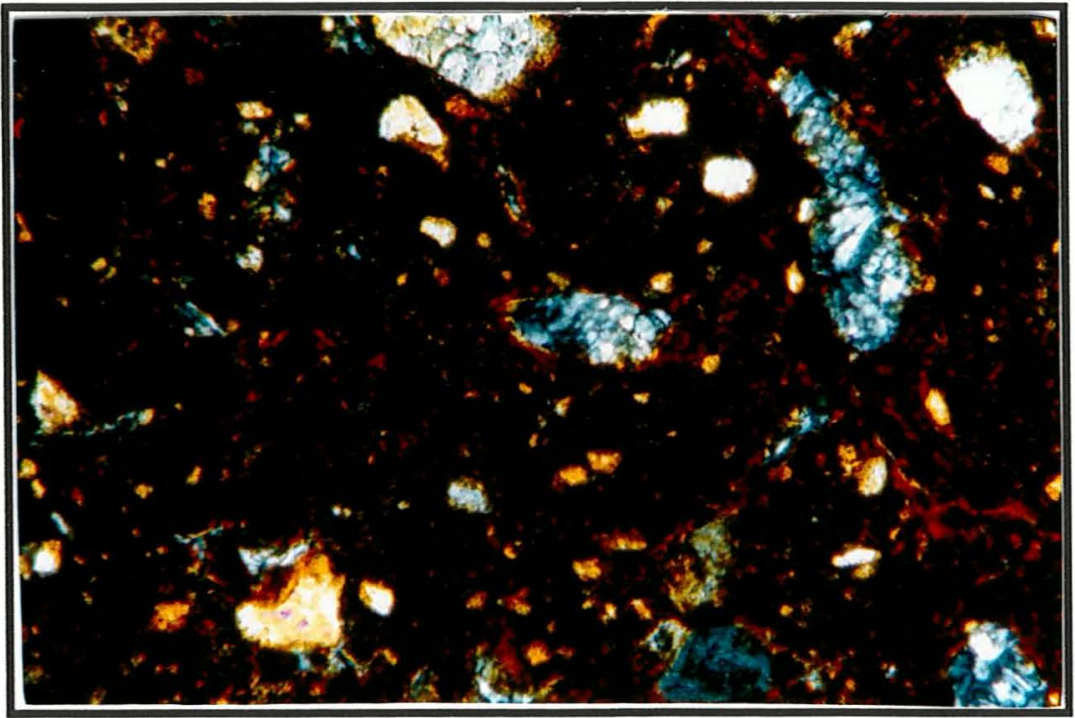

Figura 26 - Idem figura anterior com luz polarizada. 


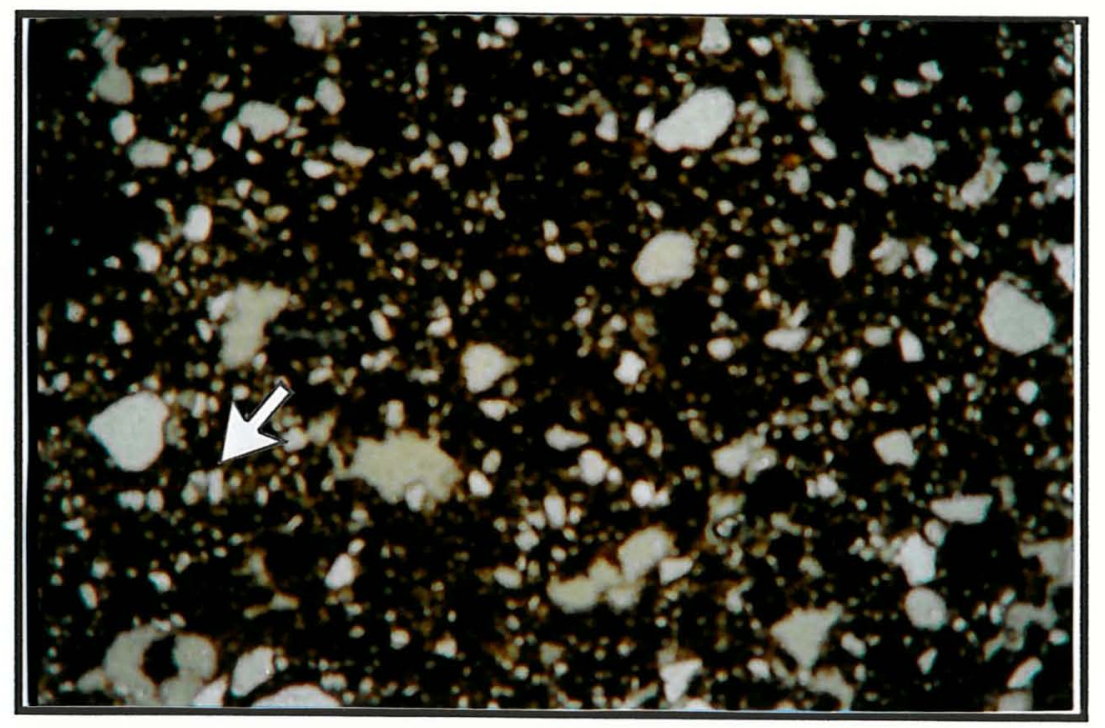

Figura 27 - Fotomicrografia de campo representativo do perfil 2 (Ap/Bt1, 20-30 centímetros), aumento de 25 vezes, luz normal, com exemplos de grãos de esqueleto de quartzo da dimensão de areia fina se fragmentando em grãos de tamanho silte. (seta branca).

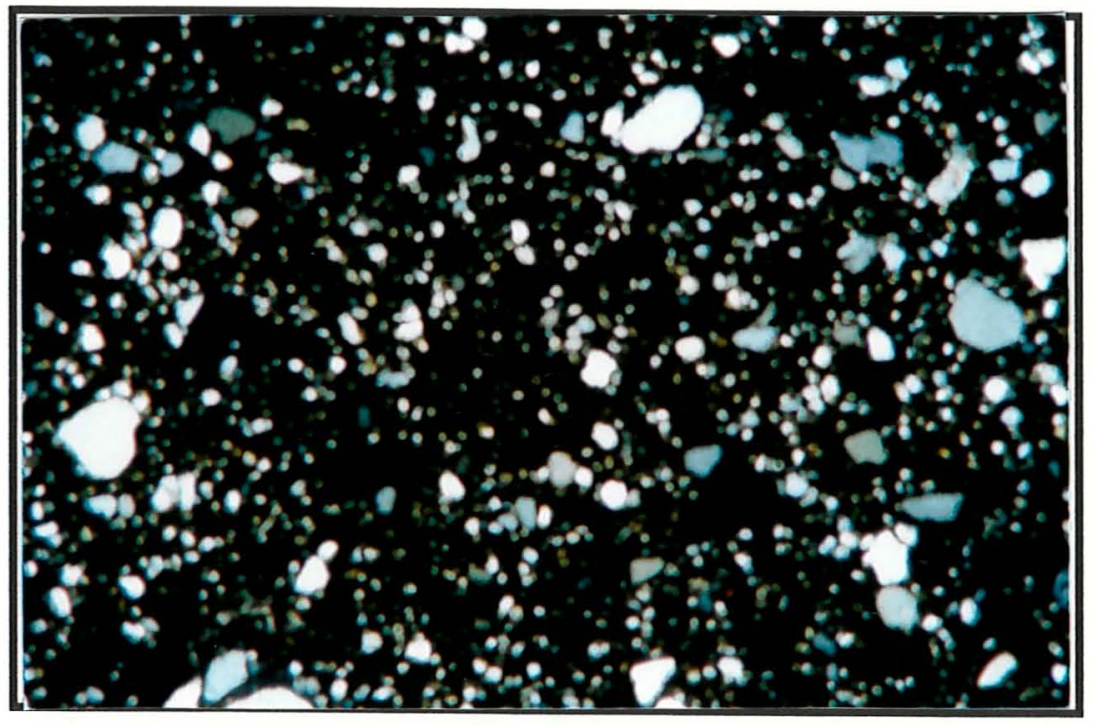

Figura 28 -Idem anterior com luz polarizada. 


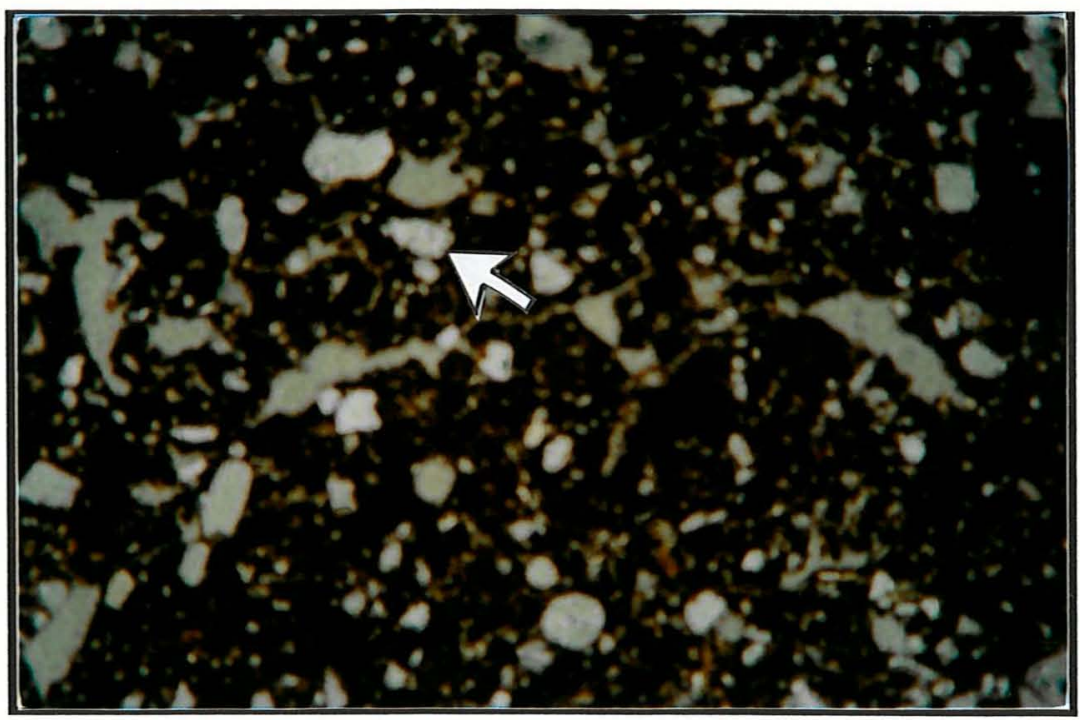

Figura 29 - Fotomicrografia de campo representativo do perfil 2 (Bt1/Bt2, 70-80 centímetros), aumento de 25 vezes, luz normal, com exemplos de grãos de esqueleto de quartzo da dimensão de areia fina se fragmentando em grãos de tamanho silte (seta branca).

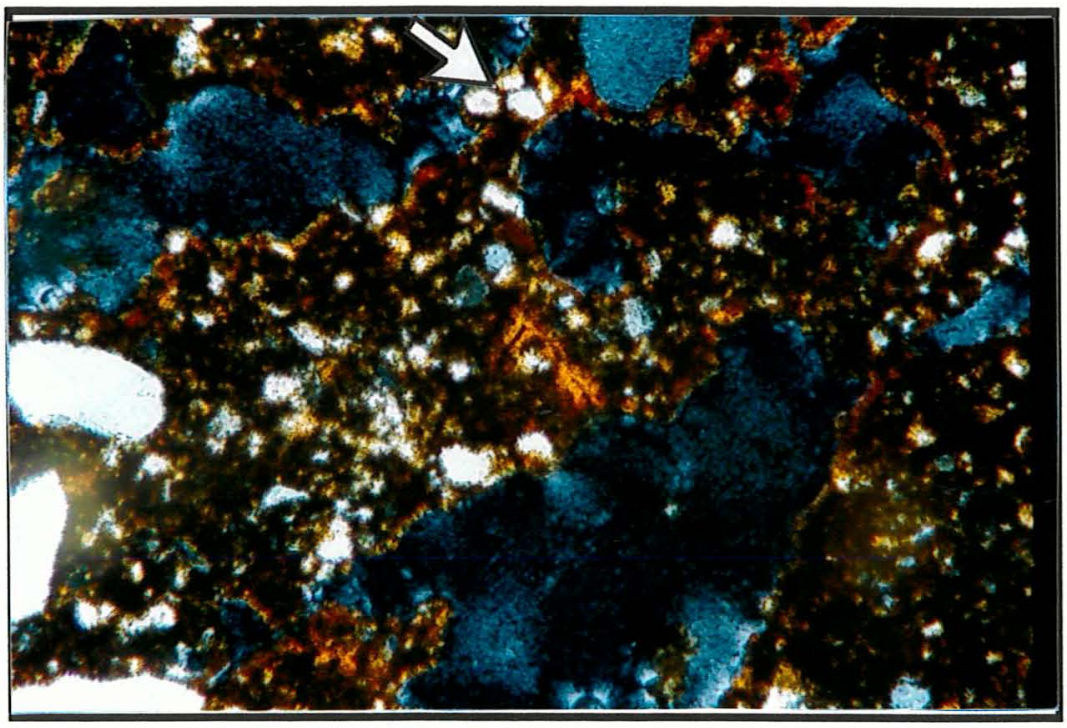

Figura 30 - Fotomicrografia do perfil 2 (Bt1/Bt2, 70-80 centímetros), aumento de 100 vezes, luz polarizada, com exemplos de grãos de esqueleto de quartzo da dimensão de areia muito fina se fragmentando em grãos de tamanho silte, plasma massépico e pequeno cutan de iluviação no centro da foto. 


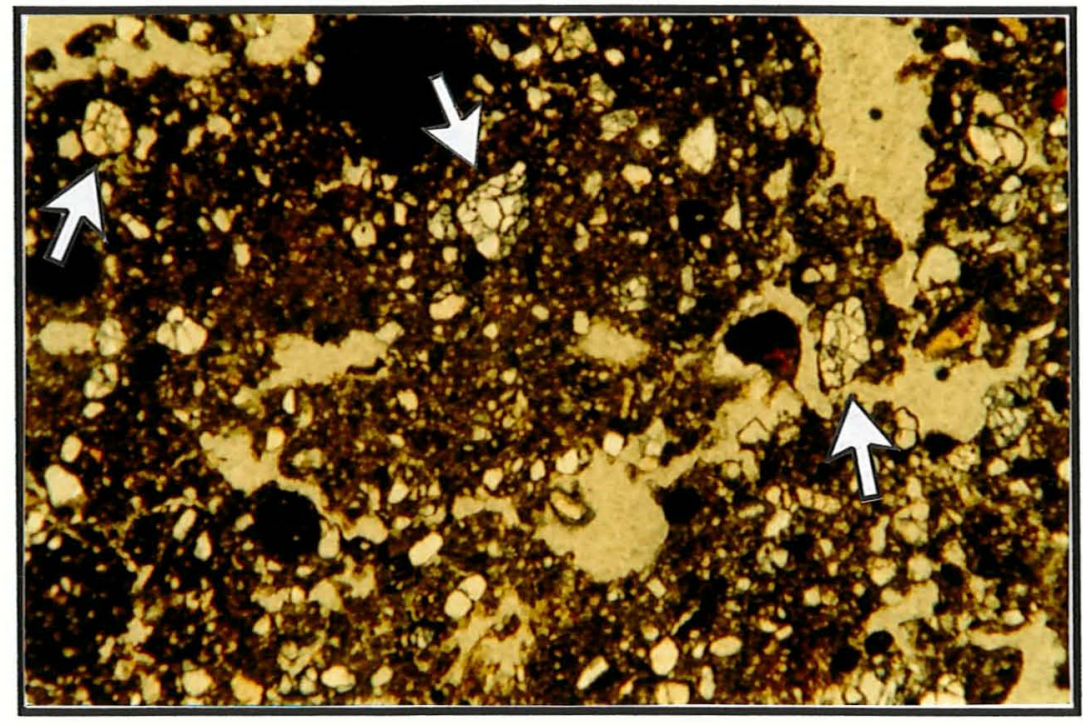

Figura 31 - Fotomicrografia de campo representativo do perfil 3 (Ap/Bt1), aumento de 25 vezes, luz normal, com exemplos de grãos de esqueleto de quartzo da dimensão de areia fina se fragmentando em grãos de tamanho silte. (seta branca).

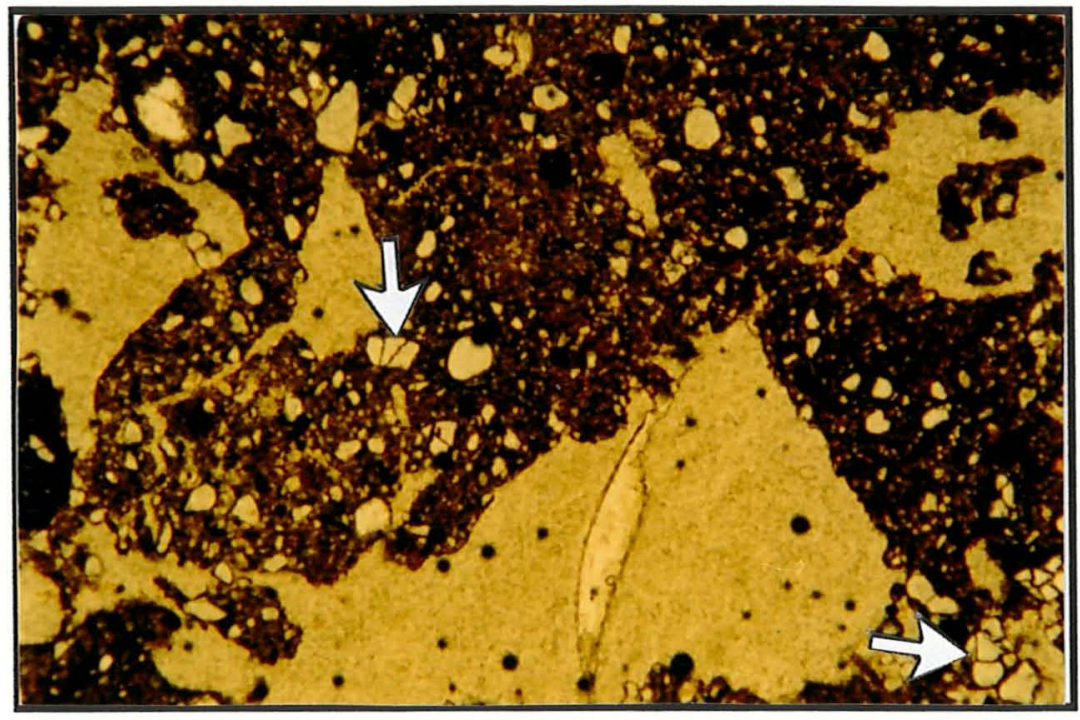

Figura 32 - Fotomicrografia do perfil 3 (Ap/Bt1), aumento de 25 vezes, luz normal, com exemplos de grãos de esqueleto de quartzo da dimensão de areia fina iniciando fissuração em grãos de tamanho silte. (seta branca). 


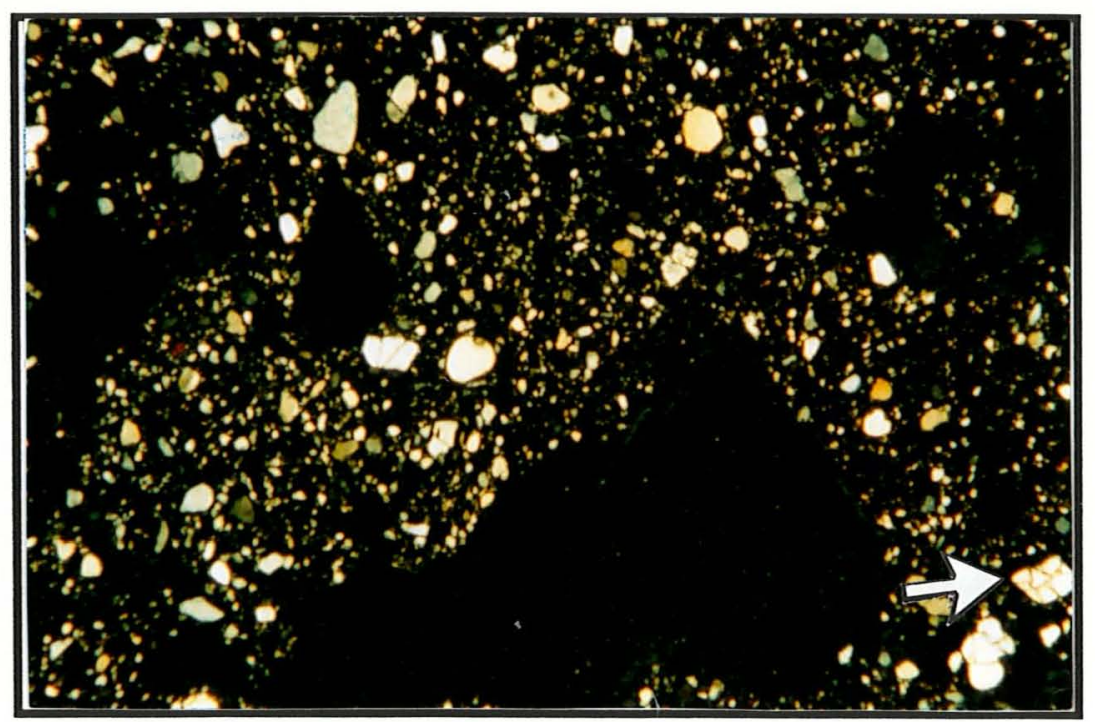

Figura 33 - Idem figura anterior com LP.

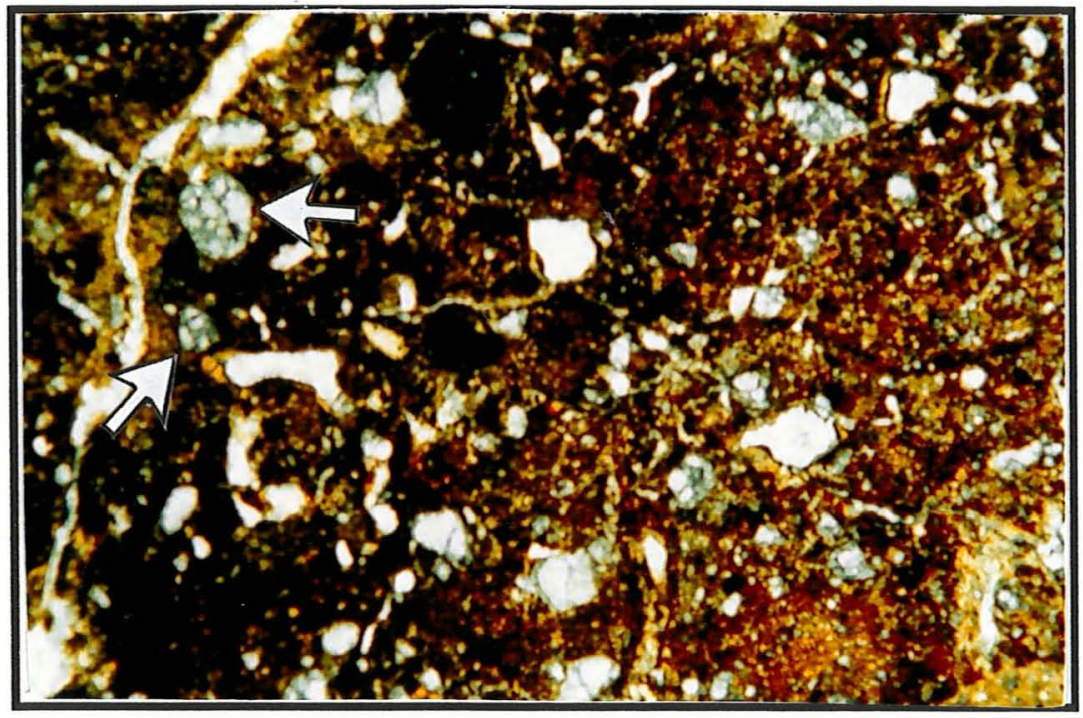

Figura 34 - Fotomicrografia do perfil 3 (Btg1/Btg2), campo representativo, aumento de 25 vezes, luz normal, com exemplos de grãos de esqueleto de quartzo da dimensão de areia fina se fissurando em grãos de tamanho silte (seta branca). 


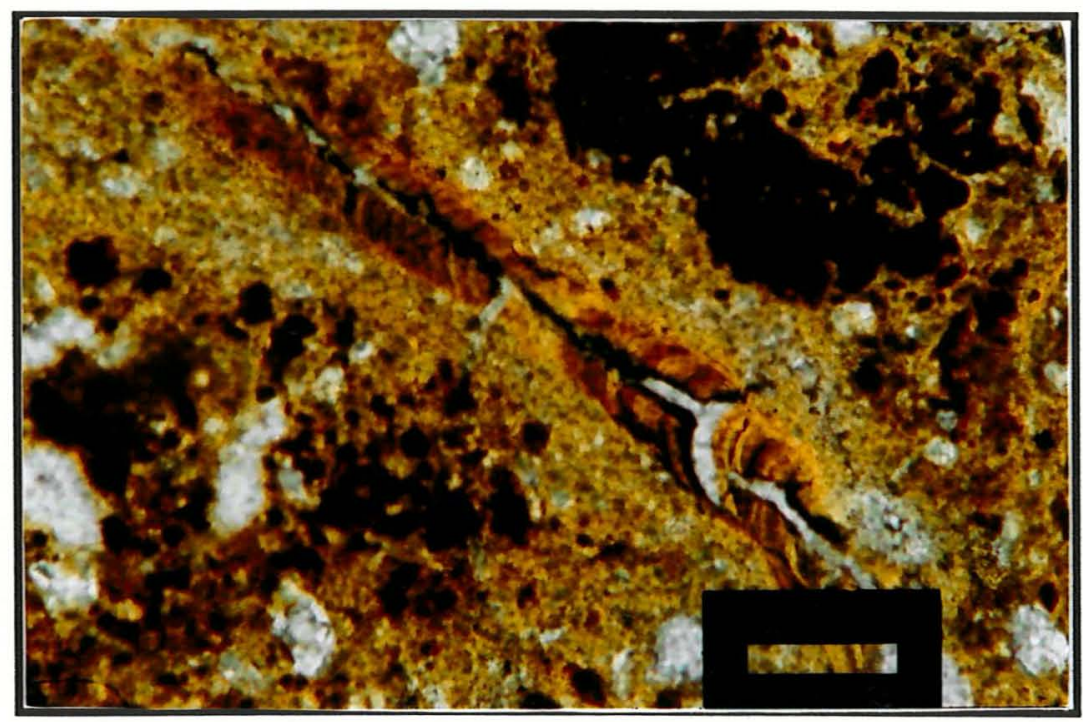

Figura 35 - Fotomicrografia do perfil 3 (Btg1/Btg2), aumento de 100 vezes, luz normal, cutan de transformação em poro com crescimento de cristalitos perpendicular a parede do poro (extinção de luz paralela a parede do poro) com posterior fissuração.

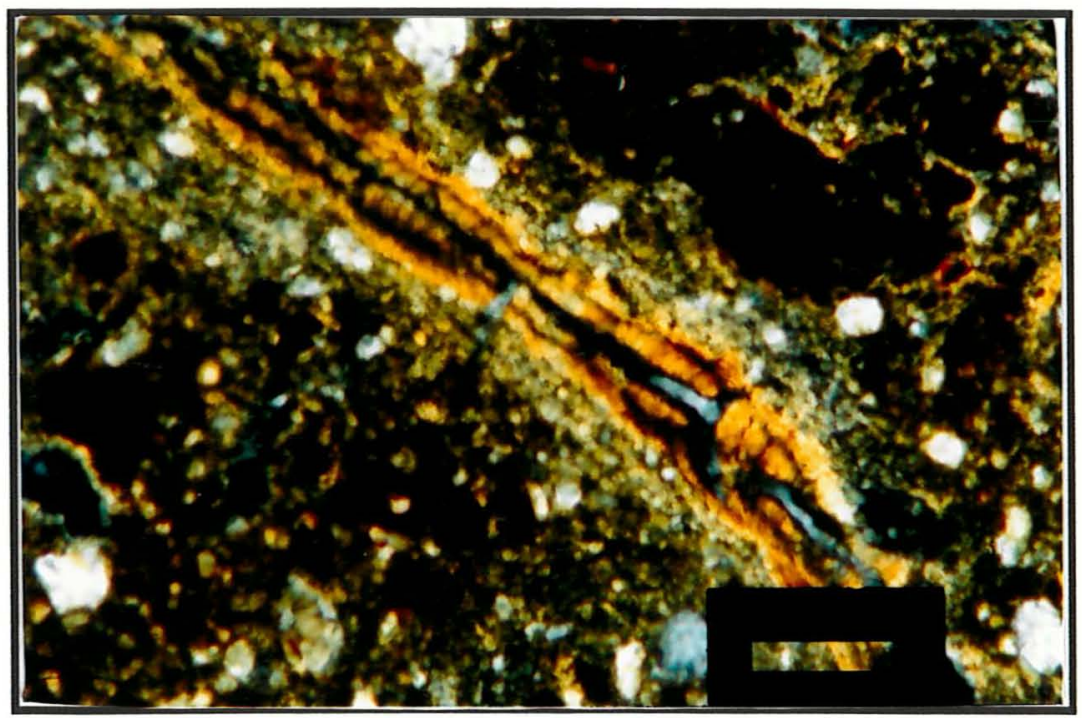

Figura 36 - Idem figura anterior com luz polarizada. 


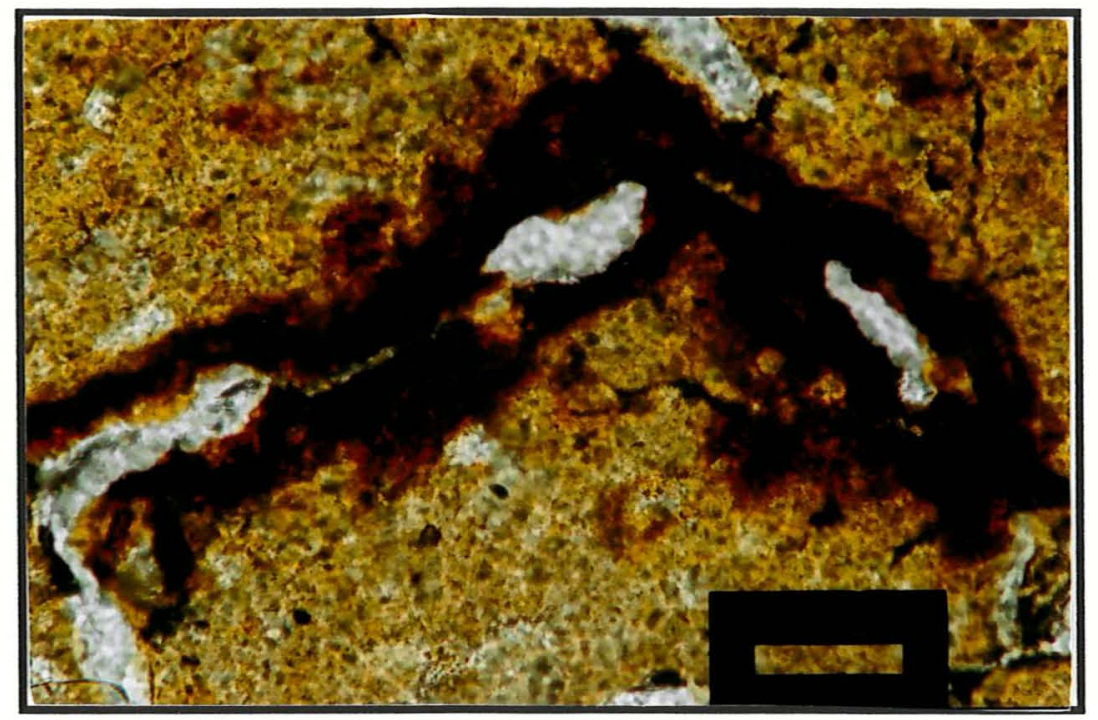

Figura 37 - Fotomicrografia do perfil 3 (Btg1/Btg2), aumento de 100 vezes, luz normal, ferran indicando a perda de ferro por difusão através de poro fissural.

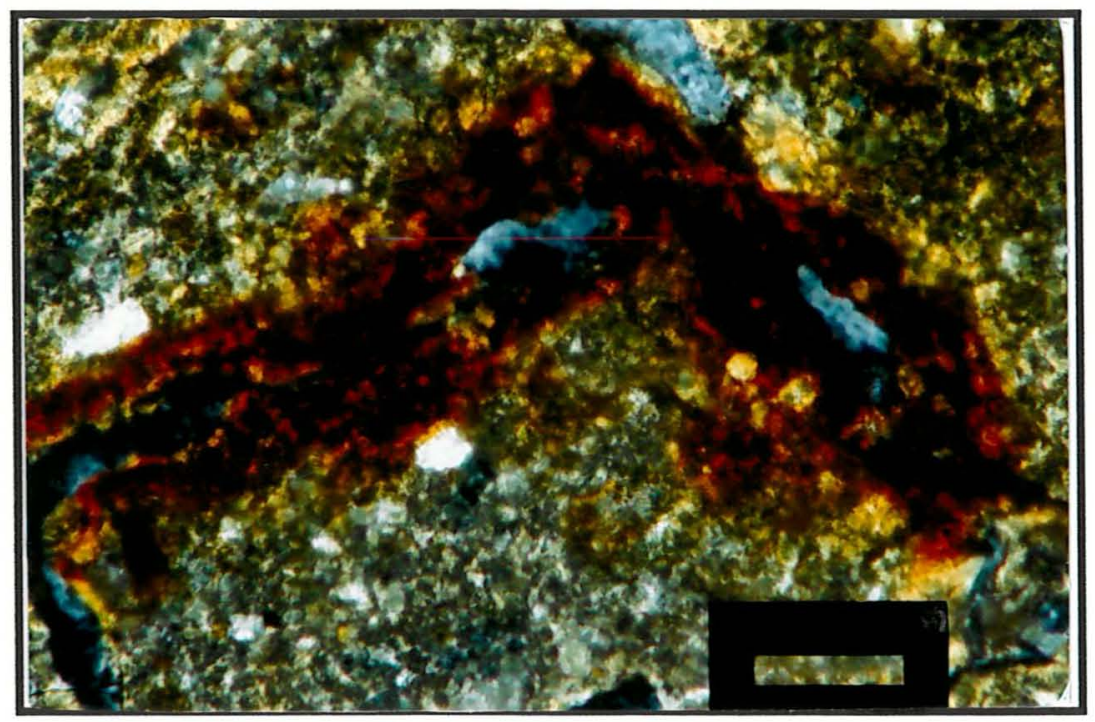

Figura 38 - Idem figura anterior com luz polarizada. 


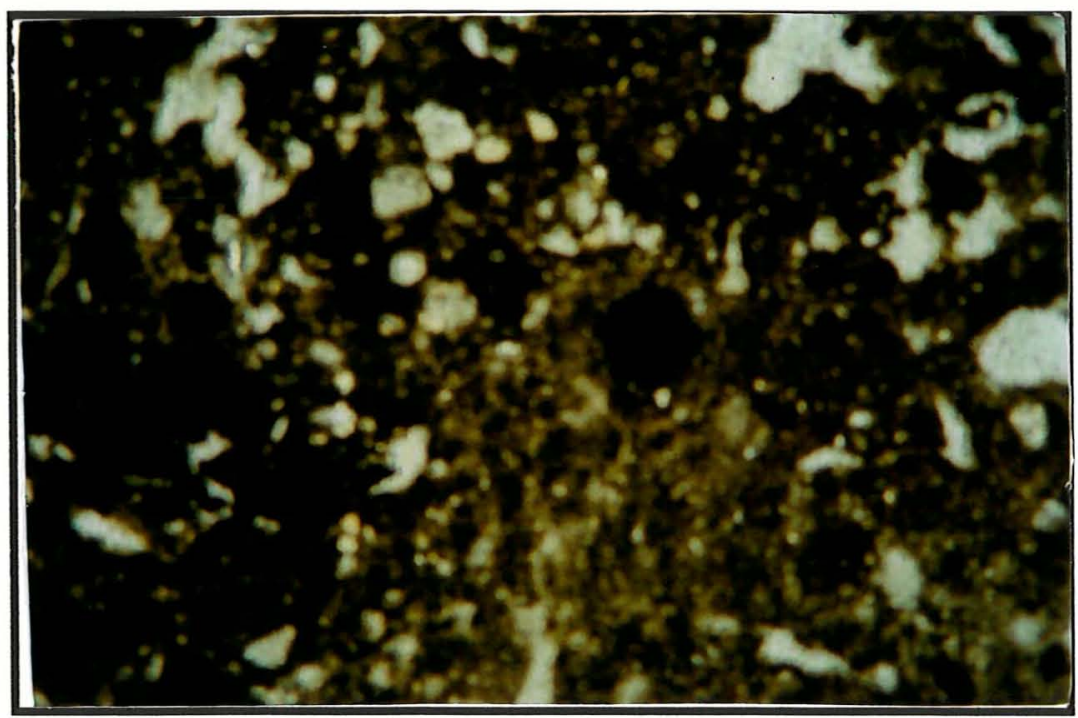

Figura 39 - Fotomicrografia de campo representativo do perfil 4 (Eg, 3545 centímetros), aumento de 25 vezes, luz normal.

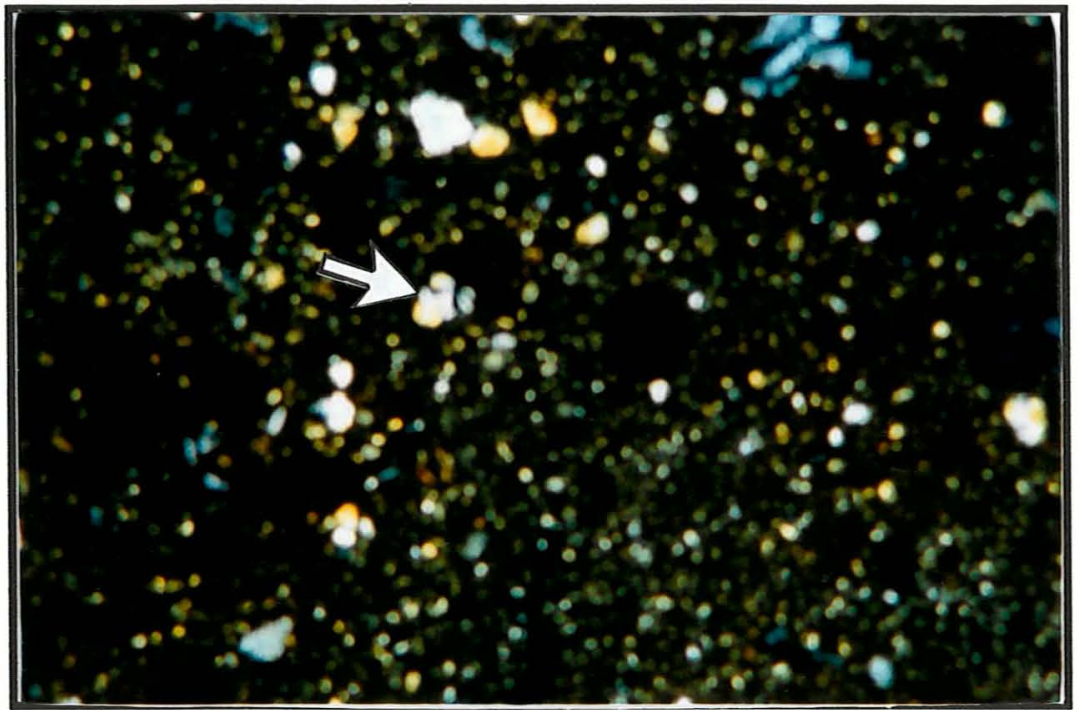

Figura 40 - Idem figura anterior com luz polarizada, com exemplos de grãos de esqueleto de quartzo da dimensão de areia fina se fragmentando em grãos de tamanho silte (seta branca). 


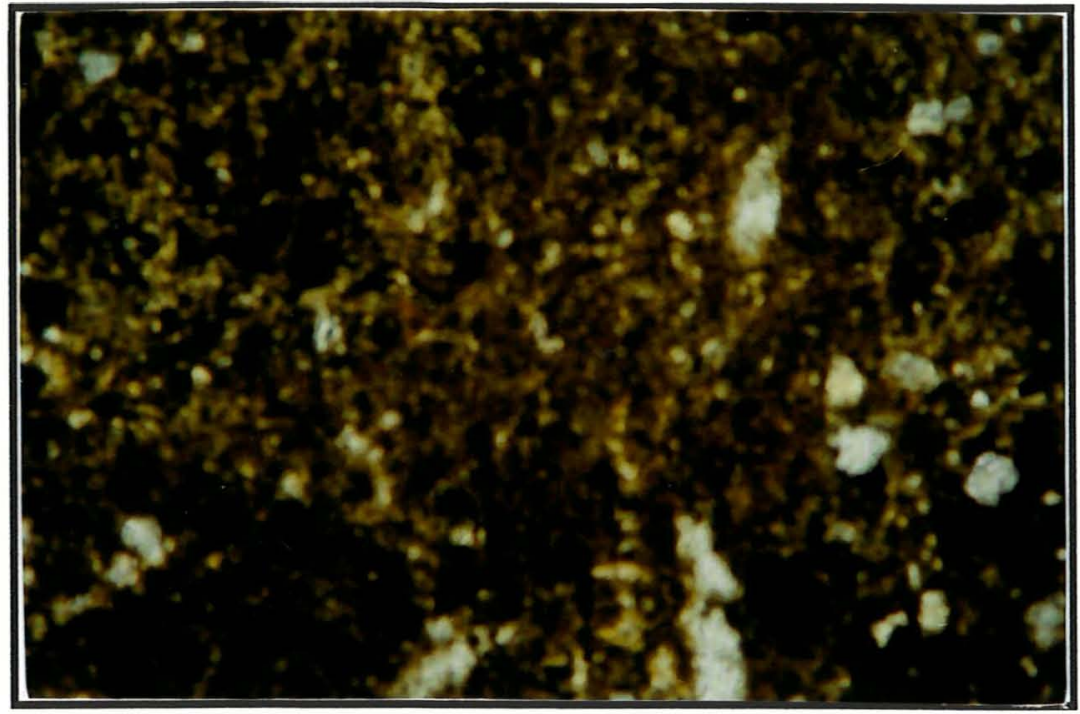

Figura 41 - Fotomicrografia de campo representativo do perfil 4 (Btgf, 129-135 centímetros), aumento de 25 vezes, luz normal.

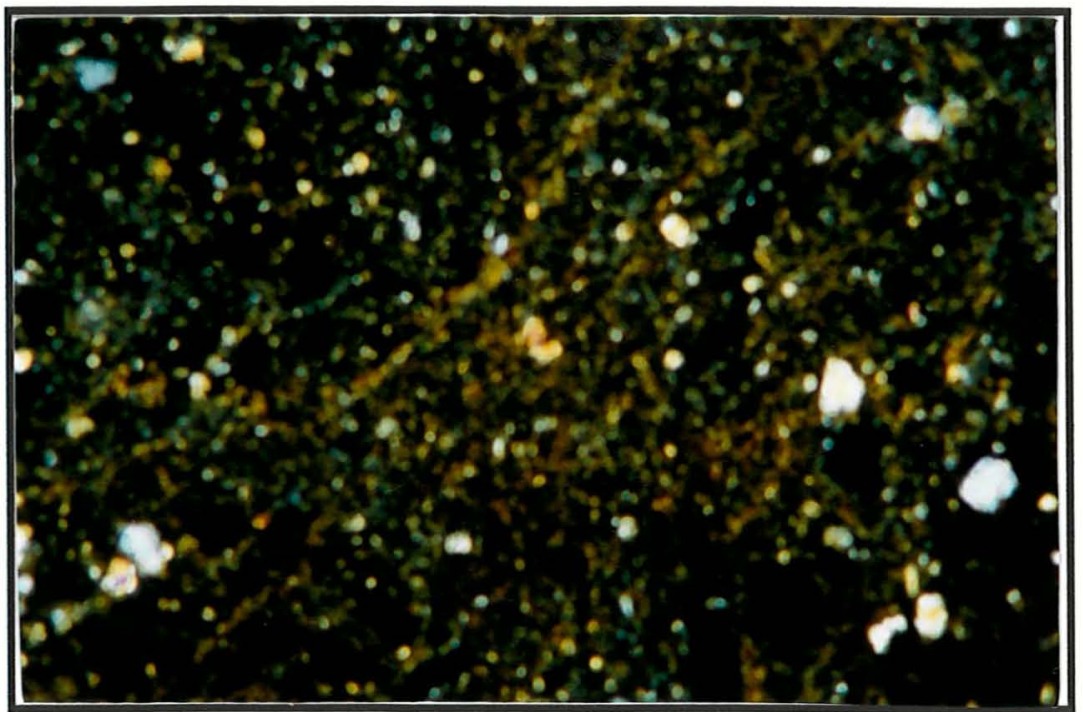

Figura 42 - Idem figura anterior com luz polarizada, mostrando plasma bimassépico e redução no teor de silte. 


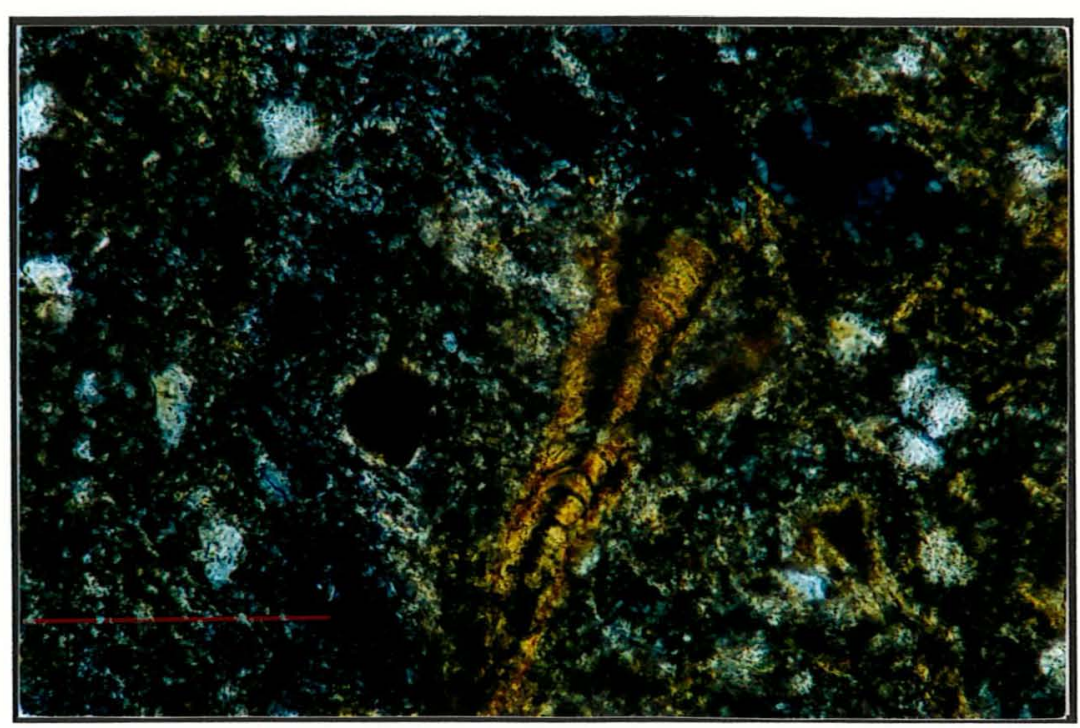

Figura 43 - Fotomicrografia do perfil 4 (Btgf, 129-135 centimetros), aumento de 100 vezes, luz polarizada, cutan de transformação associado à porosidade fissural, com extinção de luz paralelo a parede do poro, indicando um crescimento de cristais perpendiculares a parede do poro.

As relações entre as frações areia fina/areia total e areia muito fina/areia total não apresentam grandes discrepâncias verticais e laterais, indicando a ausência de descontinuidades litológicas importantes em relação à granulometria. Grandes alterações nestas relações podem indicar descontinuidades litológicas ou podem ser provocadas por coluvionamentos (Brinkman, 1979; Cabrera-Martinez et al. 1988). A análise mineralógica por difração de raios X da fração silte nos perfis 1 e 4 (figuras 47 e 48), indica os mesmos minerais, com pirofilita, quartzo e feldspatos, concordando com Amaral (1971), sendo ainda identificados formas mal cristalizadas de quartzo (cristobalita, trydimita e opala), micas, pirita, hematita, goetita, dickita, caolinita, berthierina férrica e ferrosa, nsutita e MnS (fontes de $\mathrm{Mn}$ ), anatásio e rutilo (fonte de Ti), zirção, e minerais típicos de sedimentos calcários, segundo Besoain (1985), como aragonita, antigorita, hidrocalcita e spinel. Nas figuras 44 e 45, acompanhando a identificação dos minerais, estão colocados os espaçamentos basais em Å segundo Brindley \& Brown (1980).

As relações das frações da areia com a areia total, a mineralogia da fração silte, as exposições geológicas próximas nas pedreiras e a observação da continuidade lateral de leitos de sílex nos perfis, indicam uma continuidade geológica granulométrica, mineralógica e estrutural. 
Os perfis 1,2 e 3 possuem, em média, $39 \%$ de argila e o perfil 4 apresentam $47 \%$ de argila nos horizontes A. Os horizontes B possuem para todos os perfis em média $66 \%$ de argila. A relação silte/argila tem média 0,9 para os horizontes A e 0,4 para os horizontes $\mathrm{B}$ da toposseqüência, com pequena variação em relação à média. A relação da argila do Ap e os Bt 2, dos perfis 1 e 2, Btg 2 do perfil 3 e Btgf do perfil 4 é de, aproximadamente, 1,5 para os perfis 1 e 4 e 2.0 para os perfis 2 e 3 . Na análise micromorfológica não foram observados cutans de iluviação em quantidade superior a 5 $\%$ em área revestindo os poros. A cerosidade presente nos horizontes $\mathrm{B}$ pode ser explicada por esforços e tensões que propiciaram a formação de plasma com estrutura massépica e bimassépica nos perfis estudados e cutans de estresse.

$\mathrm{O}$ aumento do teor de argila em profundidade nos perfis pode ser atribuído a iluviação de argila dos horizontes A no passado, sendo que os cutans de iluviação foram destruídos pela pedoturbação, no entanto, não foram encontradas a presença de pápulas significativamente em nenhuma lâmina analisada. Este aumento em profundidade no teor de argila também pode ser relativo, pelo aumento do teor de silte em direção a superficie, provocado pela destruição das litorelíqueas (bonecas e plaquetas de sílex). $\mathrm{O}$ teor de silte, aceito pela literatura como muito próximo da quantidade de minerais intemperizáveis em solos de regiões tropicais (Moniz et al., 1975) não é válido neste caso, pois a fração silte é predominante quartzosa, o mesmo se dando para a relação silte/argila normalmente menor nos horizontes superficiais em relação aos de subsuperficie. 


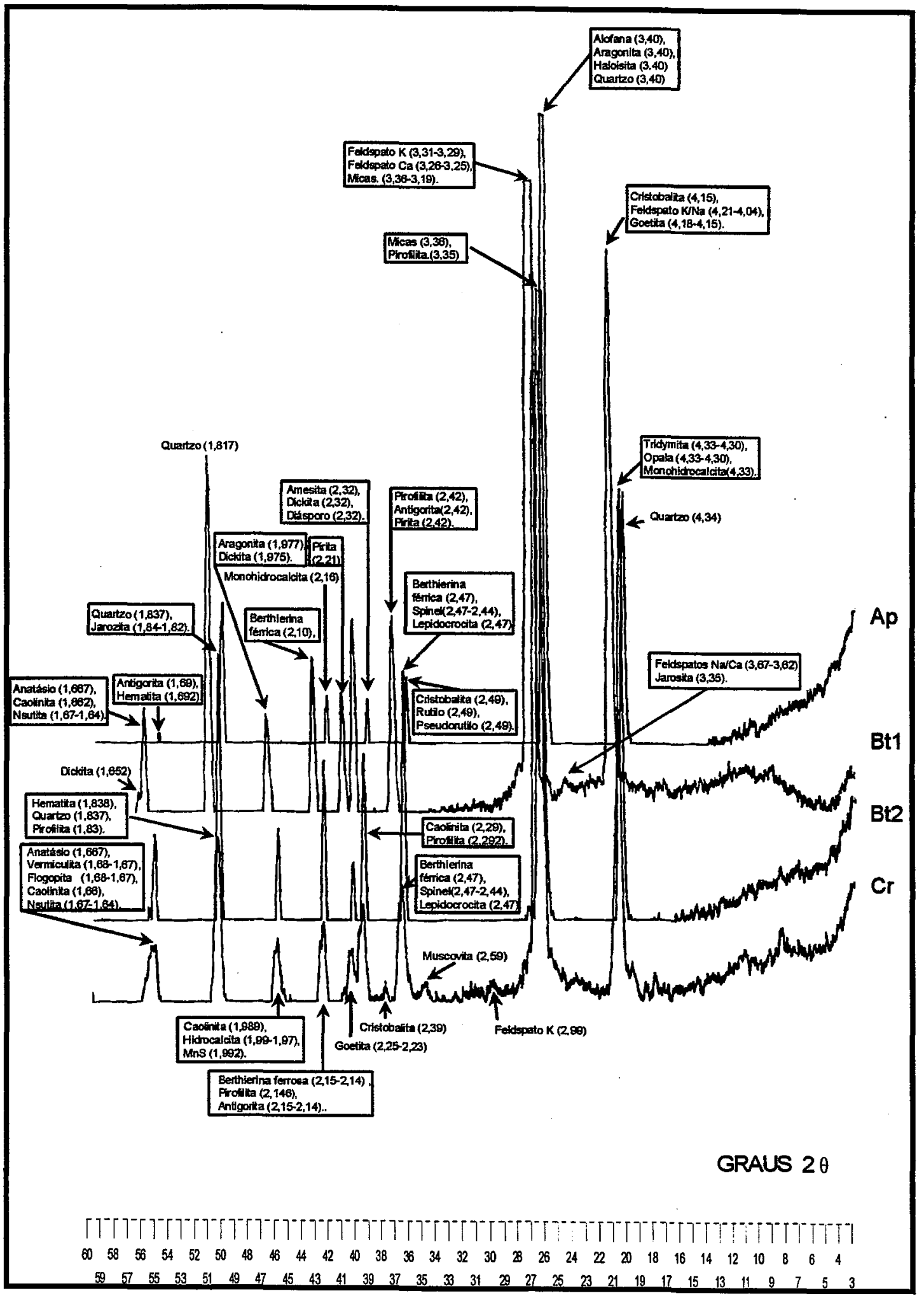

Figura 44 - Difratogramas de raio X da fração silte do perfil 1. 


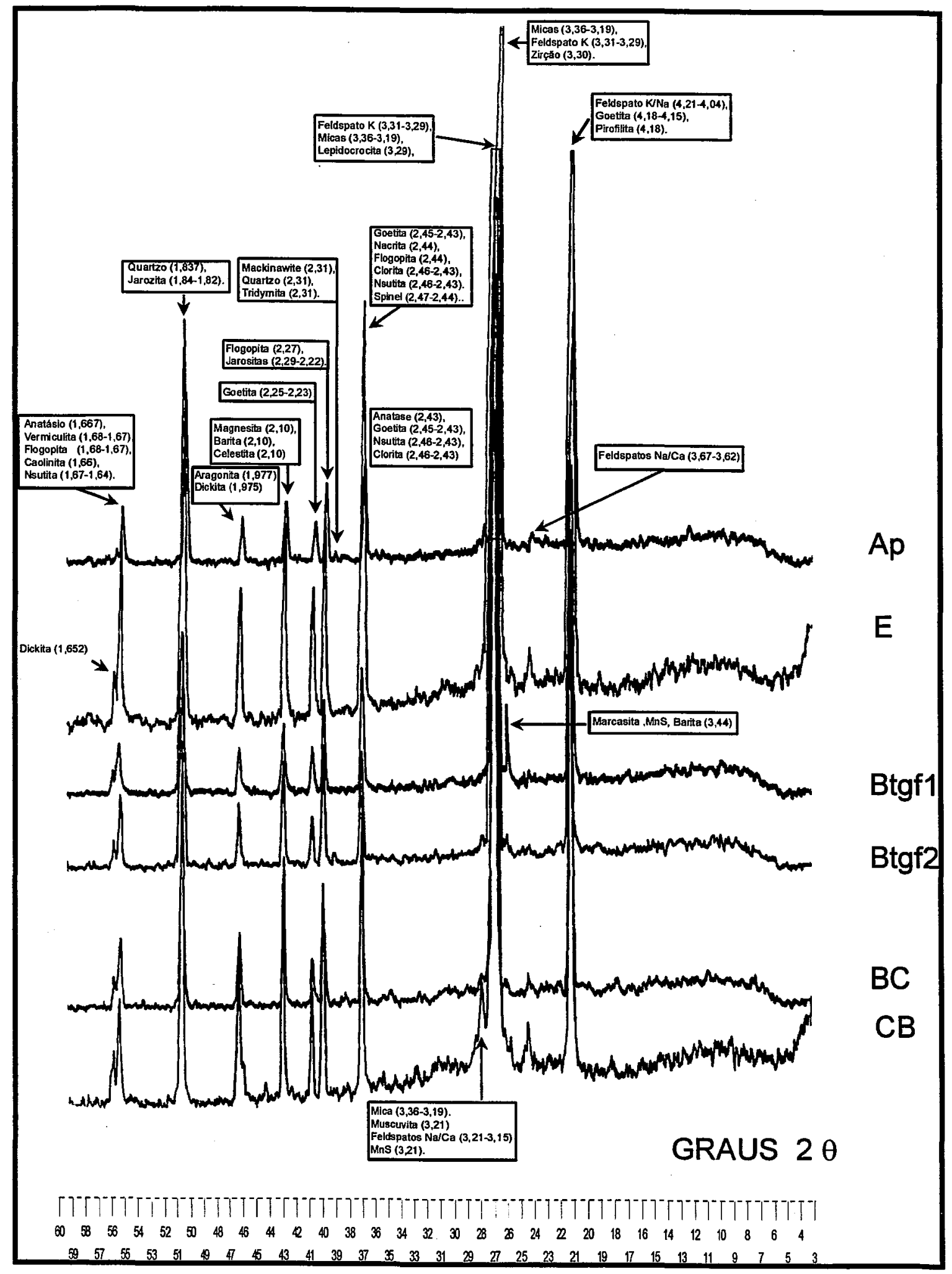

Figura 45 - Difração de raios X da fração silte do perfil 4. 


\subsubsection{Complexo sortivo}

$\mathrm{Na}$ figura 46 os valores de $\mathrm{pH}$ em água, $\mathrm{Al}$ trocável, $\mathrm{SB}$ e CTC coincidem com o aumento da hidromorfia em direção ao centro da depressão. Há a diminuição do $\mathrm{pH}$ e surgimento do Al trocável e lixiviação mais intensa das bases. Nos perfis 1,2 e 3 , os valores de CTC variam de 9,80 a 15,40 cmol. $\mathrm{Kg}^{-1}$ de solo, com média de $13,66 \mathrm{cmol} . \mathrm{Kg}^{-1}$ de solo e os valores de $\mathrm{Ki}$ variam de 2,01 a 3,38 com média de 2,53. Estes valores indicam argilominerais do grupo das caulinitas como dominantes, com contribuição de argilominerais de grade 2:1. A difração de raios $\mathrm{X}$ da fração argila do perfil 1 (figuras 47 a 50) identificou a presença de haloisita, micas, feldspatos, vermiculita, esmectita e interestratificados de mica/vermiculita e mica/clorita, sem grandes alteração entre os horizontes e no volume de alterita analisado. O perfil 4, embora possua os mesmos argilominerais do perfil 1 , possui os valores de CTC e $\mathrm{Ki}$ mais elevados da toposseqüência com uma variação da CTC de 10,60 de solo a $45,60 \mathrm{cmol} . \mathrm{Kg}^{-1}$ de solo e $\mathrm{Ki}$ de 2,53 a 3,81. Estes valores indicam uma contribuição maior de minerais de grade 2:1

\section{PRINCIPAIS CARACTERÍSTICAS DO COMPLEXO SORTIVO}

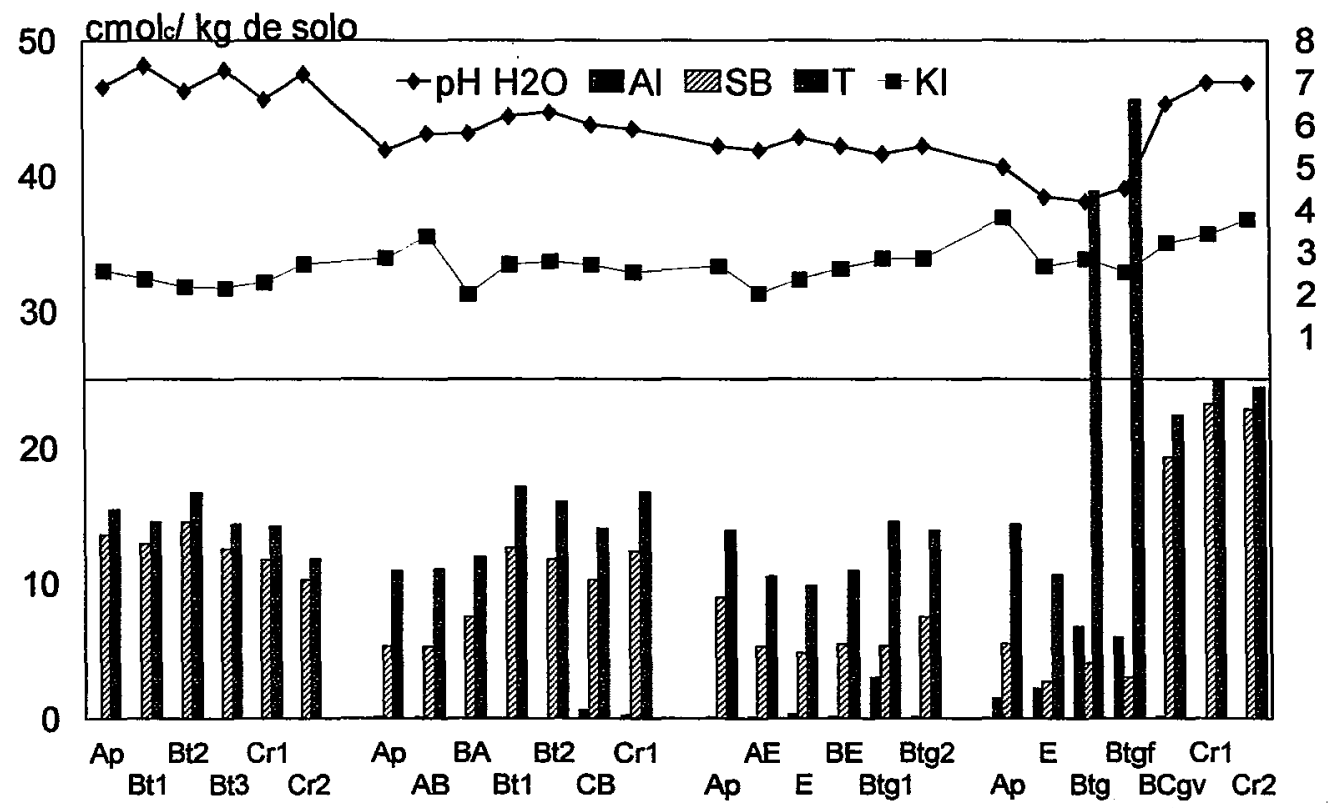

HORIZONTES E ALTERITAS

Figura 46 - Tendência em direção a jusante: diminuição do $\mathrm{pH}$ com o surgimento de $\mathrm{Al}$ trocável abaixo de $\mathrm{pH} 6.5$, contraste mais pronunciado dos valores de $\mathrm{CTC}_{7}$, redução da SB e elevação do Ki. 
no perfil 4.

A pequena diferença encontrada entre os minerais tanto vertical, quanto lateralmente indica uma litoherança dos minerais dos sedimentos da Formação Irati. O meio hidromórfico, pode tanto ter contribuído para retardar um intemperismo dos argilominerais com pode ter favorecido a formação in situ de argilominerais. A análise micromorfológica identificou a presença de cutans de transformação (argilans) no perfil 3 (figuras 35 e 36), e mais expressivamente no perfil 4 (figura 43); a vermiculita pode está sendo formada in situ pela alteração de micas e pirofilita, com a perda de $\mathrm{K}^{+}$em um meio rico em $\mathrm{Ca}^{2+}, \mathrm{Mg}^{2+}$ e ácido silícico, proveniente da destruição das frações areia fina e muito fina em fração silte no horizonte A. Nos volumes de alteração o impedimento da drenagem está favorecendo a concentração de ácido silícico e $\mathrm{Fe}^{2+}$, com a formação in situ de minerais do tipo das nontronitas, identificada pelas cores esverdeadas nos volumes de alteração, provavelmente beidelitas ferríferas intergrades para nontronita, segundo Delvigne (1983) estes minerais são comuns em alteritas profundas e solos mal drenados das regiões intertropicais, quando a drenagem deficiente, retarda ou impede a remoção de magnésio, cálcio, silício e ferro. No perfil 1 as micas podem ter se formado a partir da pirofilita, e a haloisita a partir das micas ou diretamente da pirofilita. 


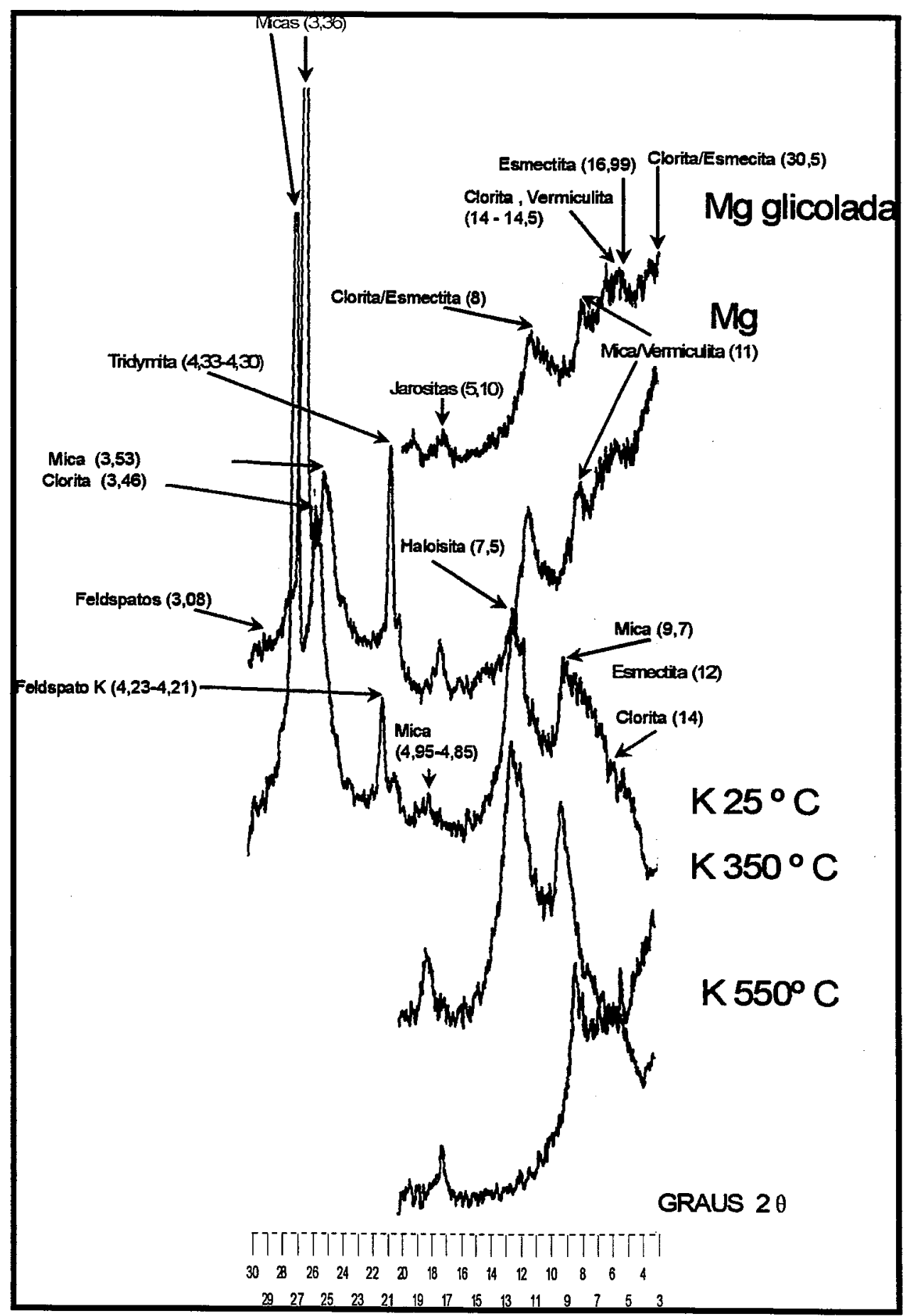

Figura 47 - Difração de raios $X$ da fração argila do horizonte Ap do perfil 1. 


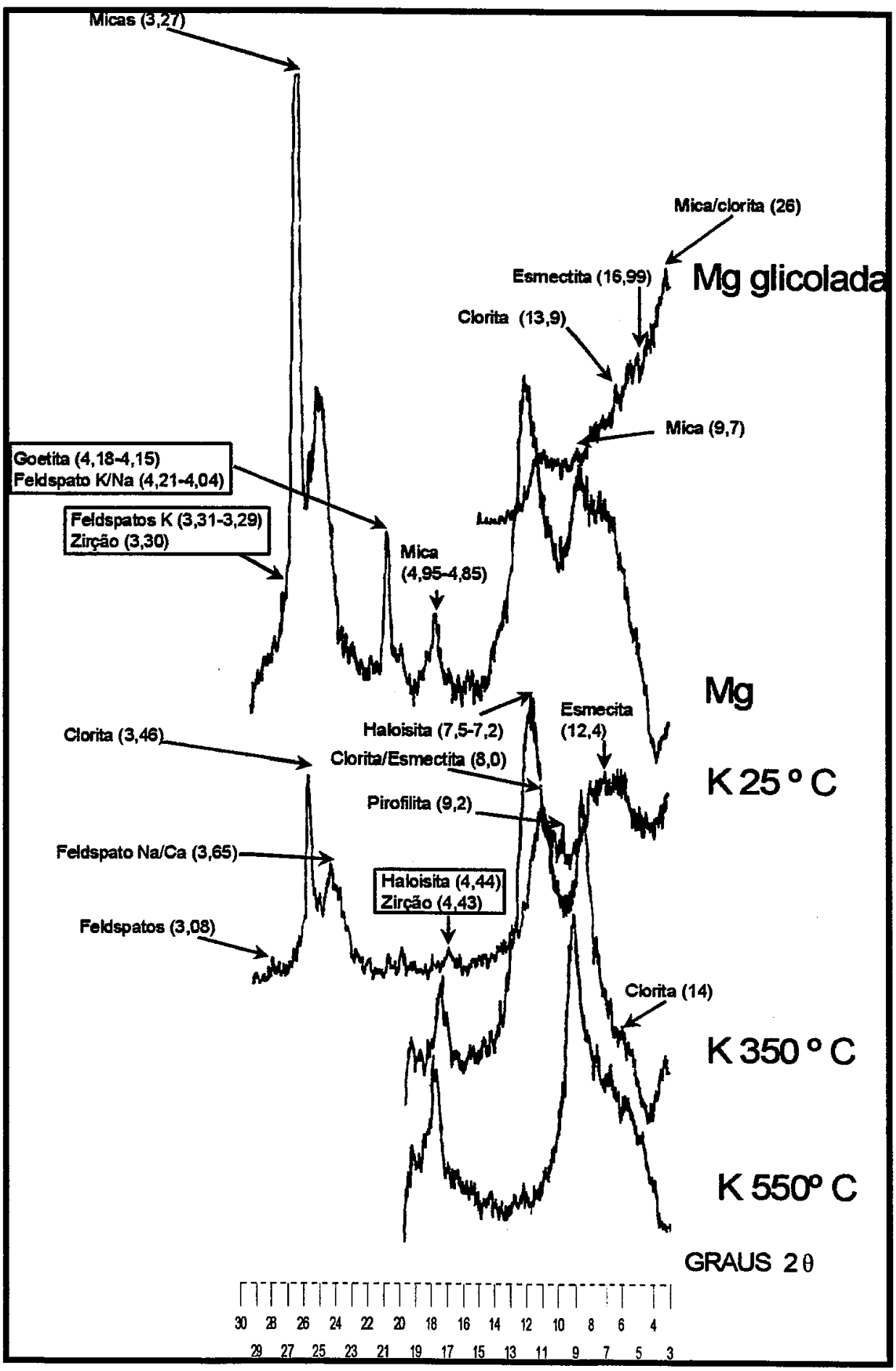

Figura 48 - Difração de raios $X$ da fração argila do horizonte Bt1 $(40-60 \mathrm{~cm})$ do perfil 1. 


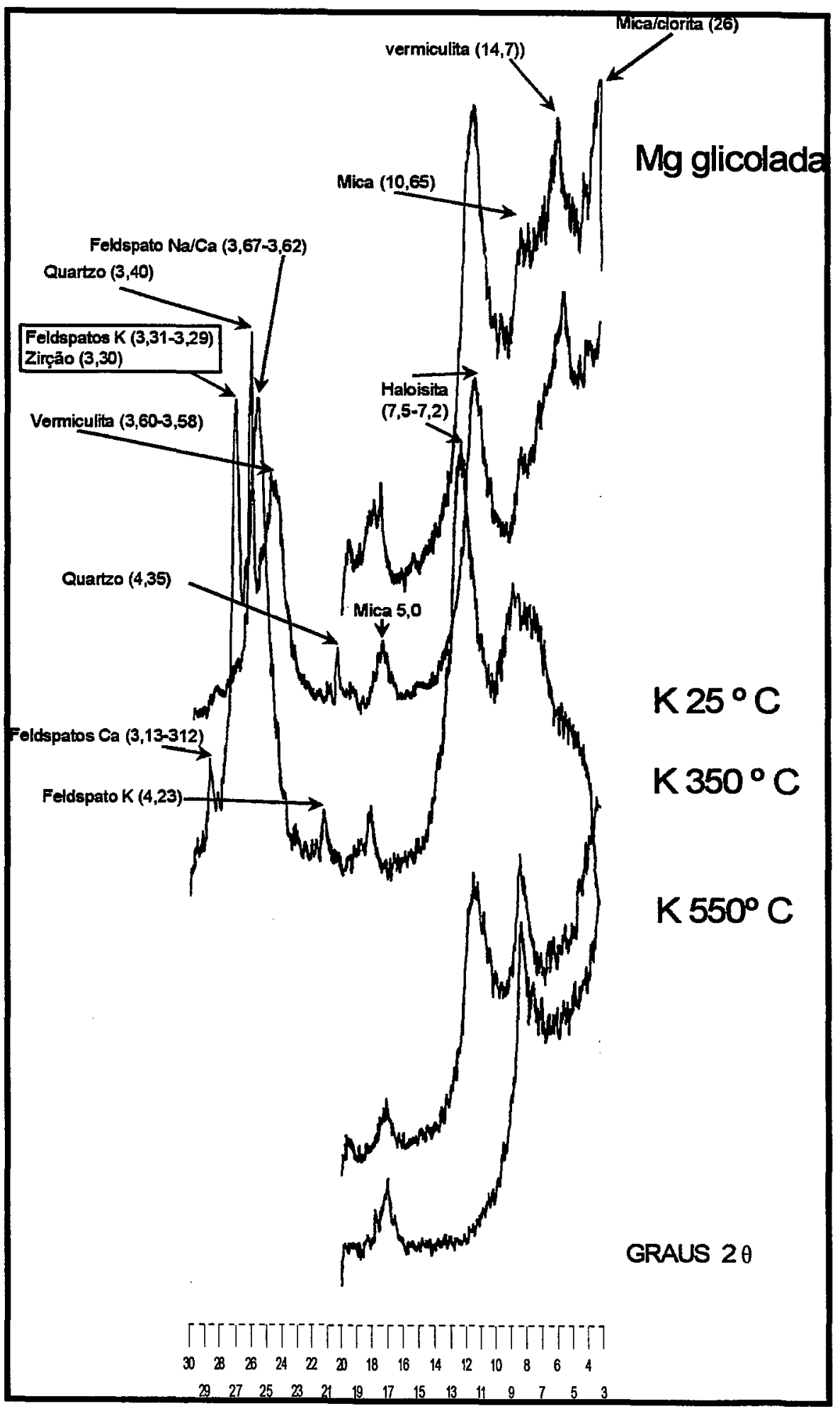

Figura 49 - Difração de raios $X$ da fração argila do horizonte Bt3 (100-120) do perfil 1. 


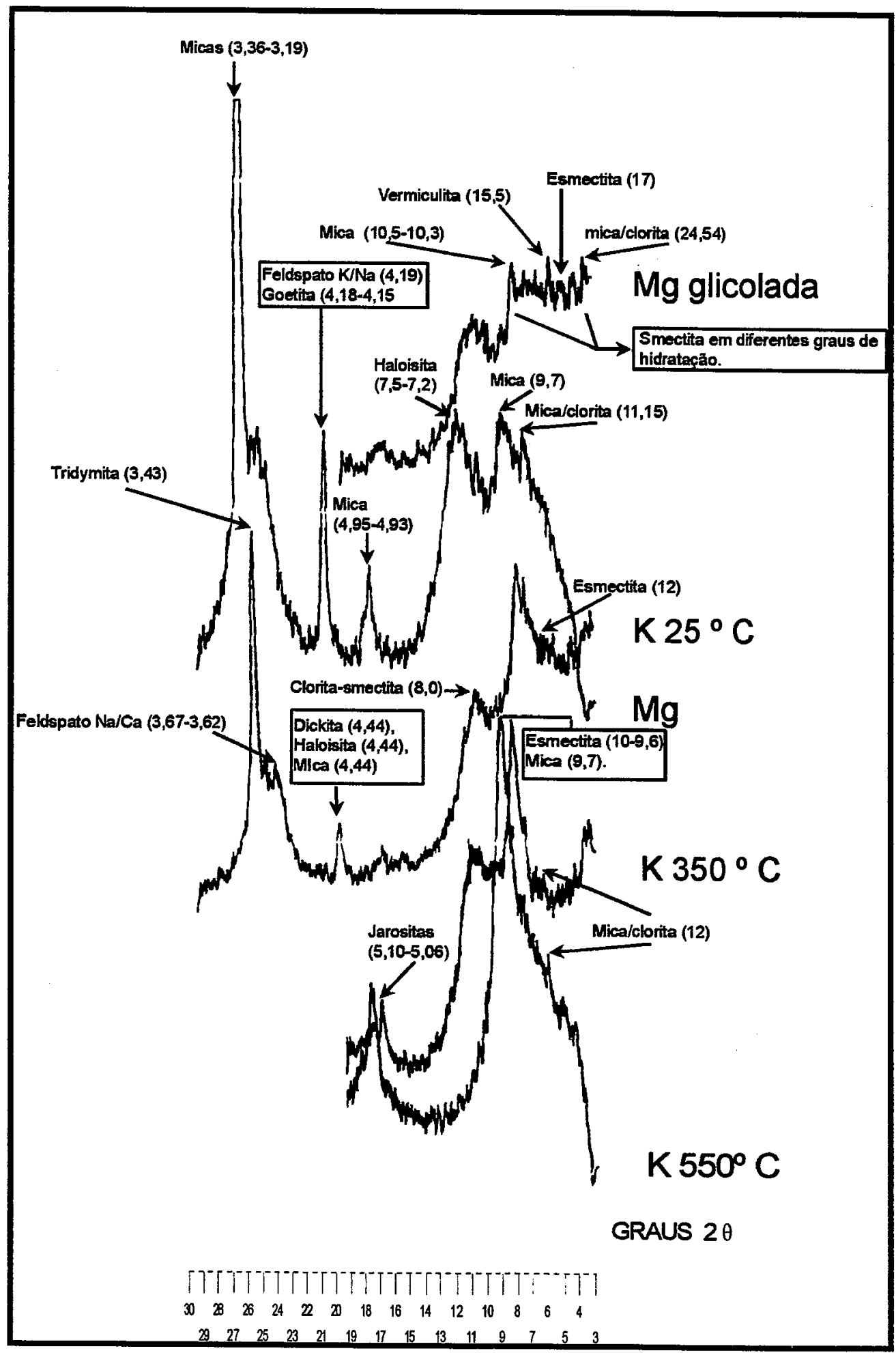

Figura 50 - Difração de raios $X$ da fração argila da camada $\mathrm{Cr}(180-195)$ do perfil 1. 


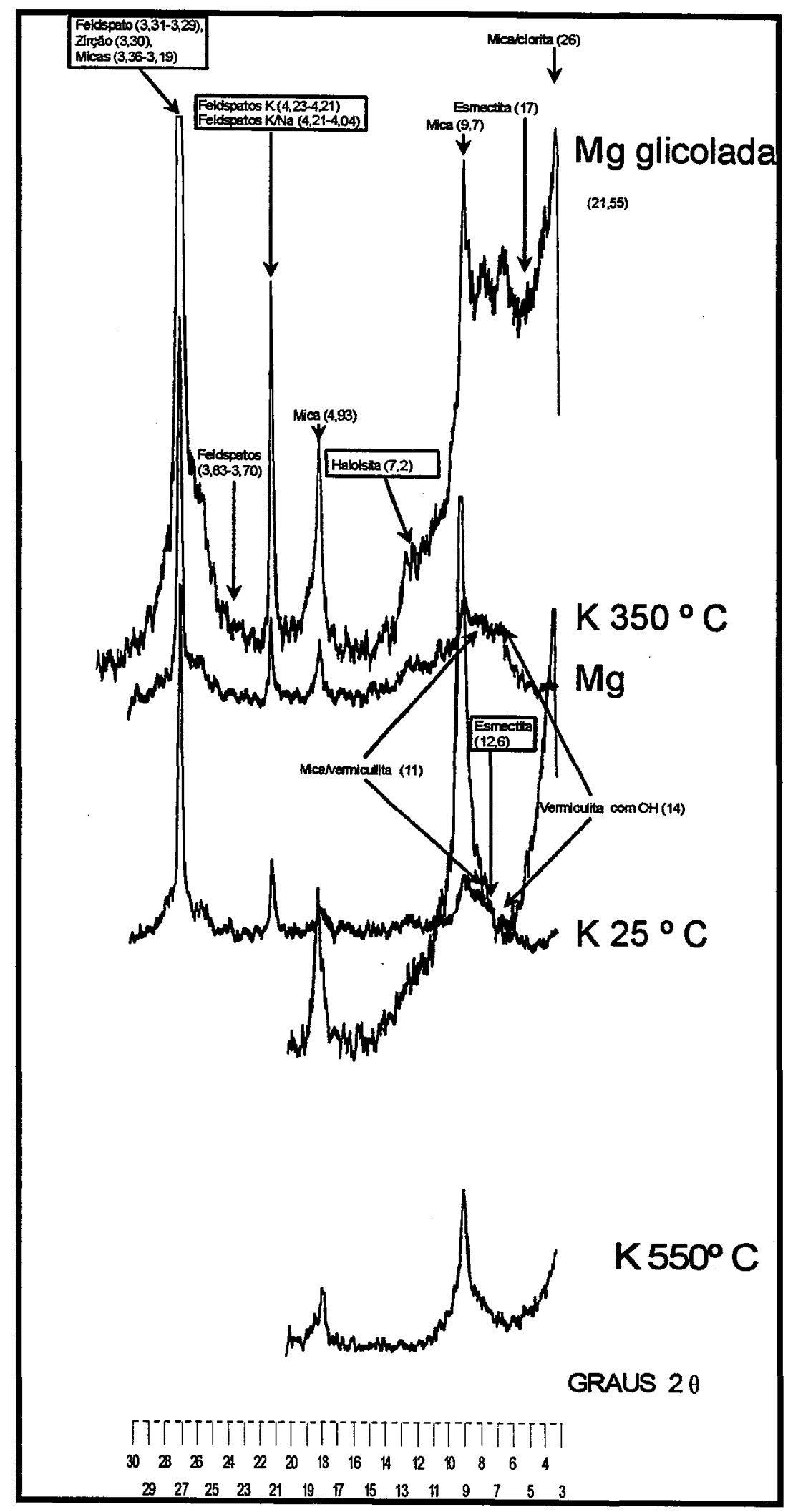

Figura 51 - Difração de raios $X$ da fração argila do horizonte $A p(10 \mathrm{~cm})$ do perfil 4 . 


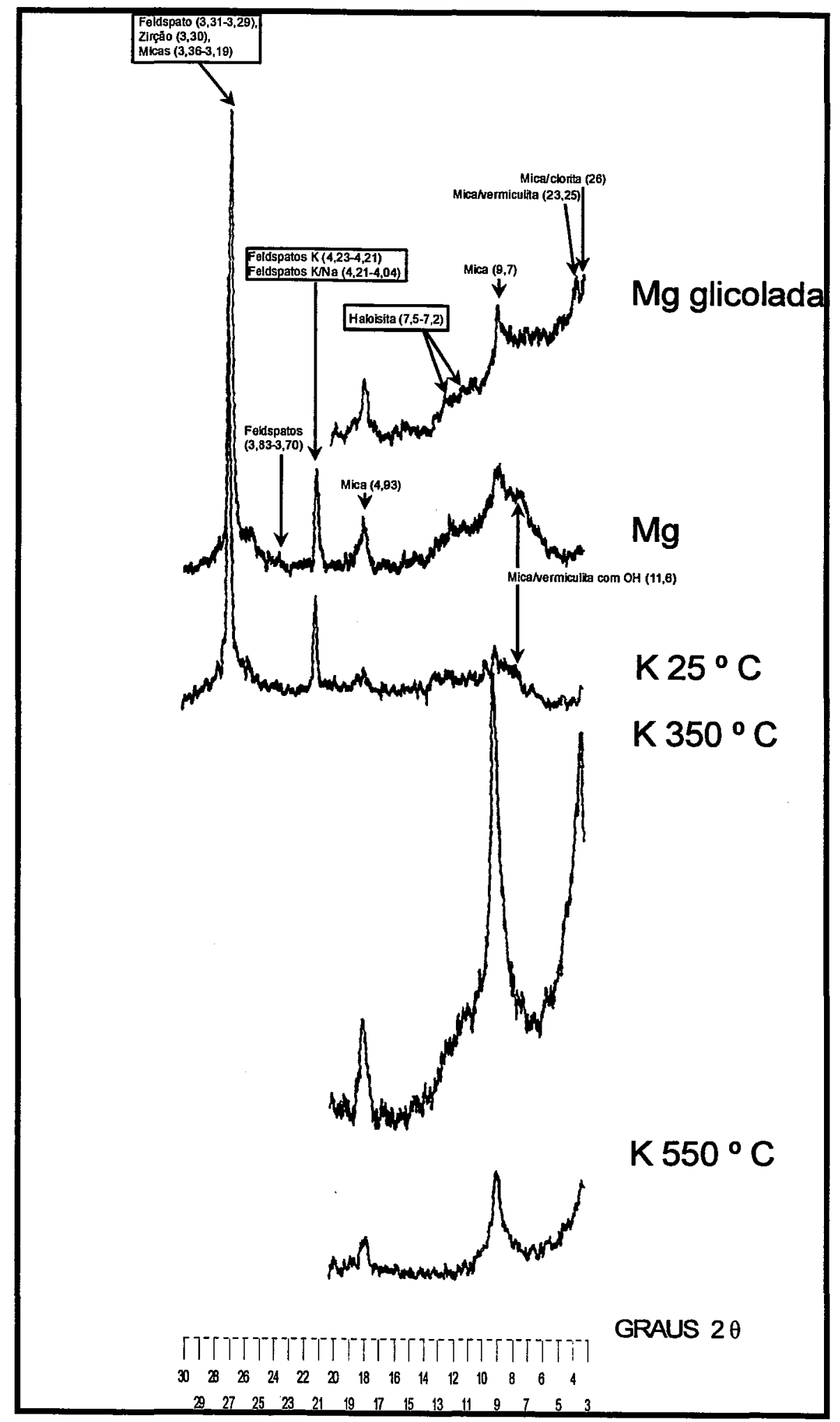

Figura 52 - Difração de raios $X$ da fração argila do horizonte $E \mathrm{~g}(28 \mathrm{~cm})$ do perfil 4. 


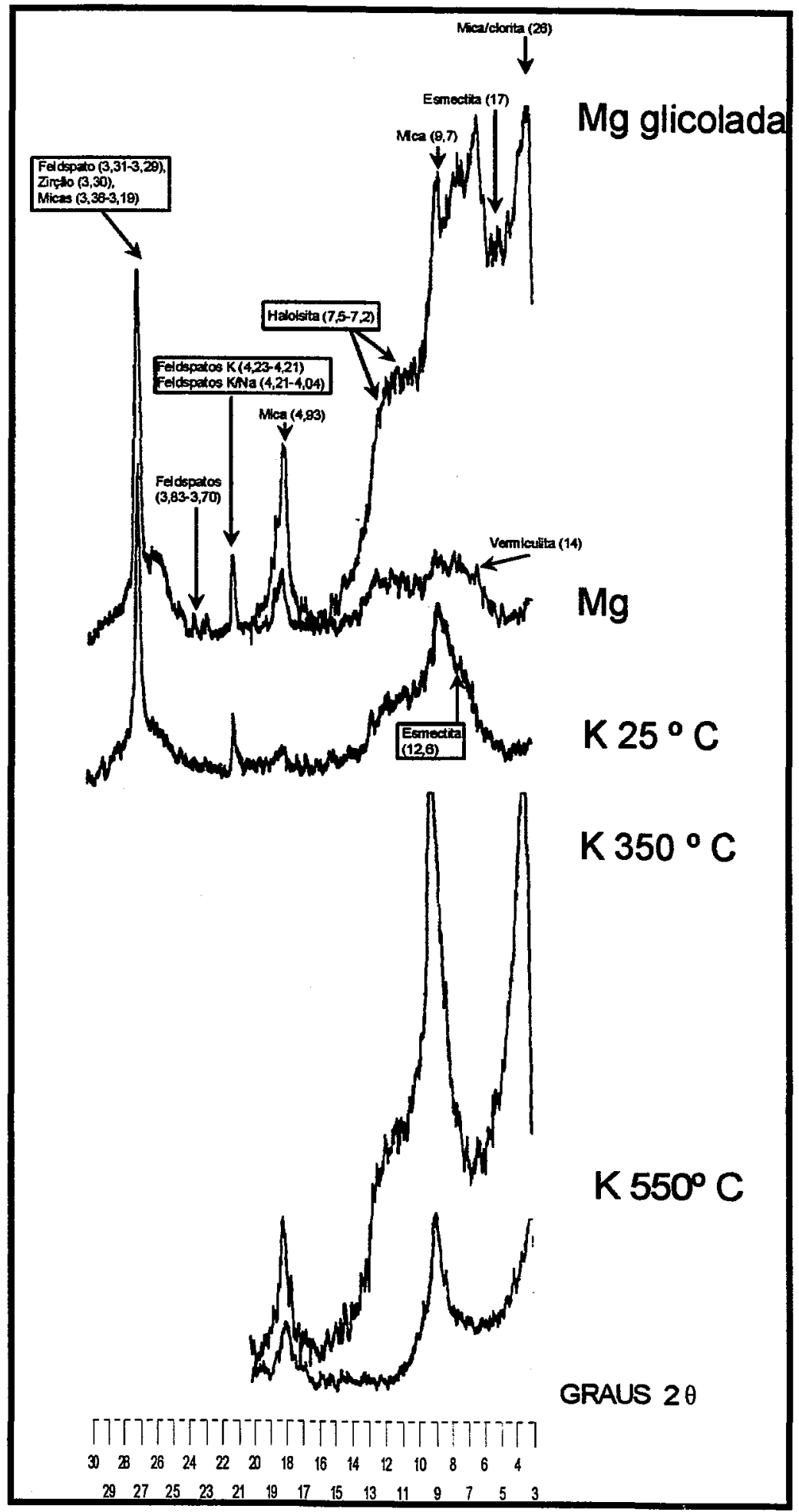

Figura 53 - Difração de raios $X$ da fração argila do horizonte Btg $(48 \mathrm{~cm})$ do perfil 4. 


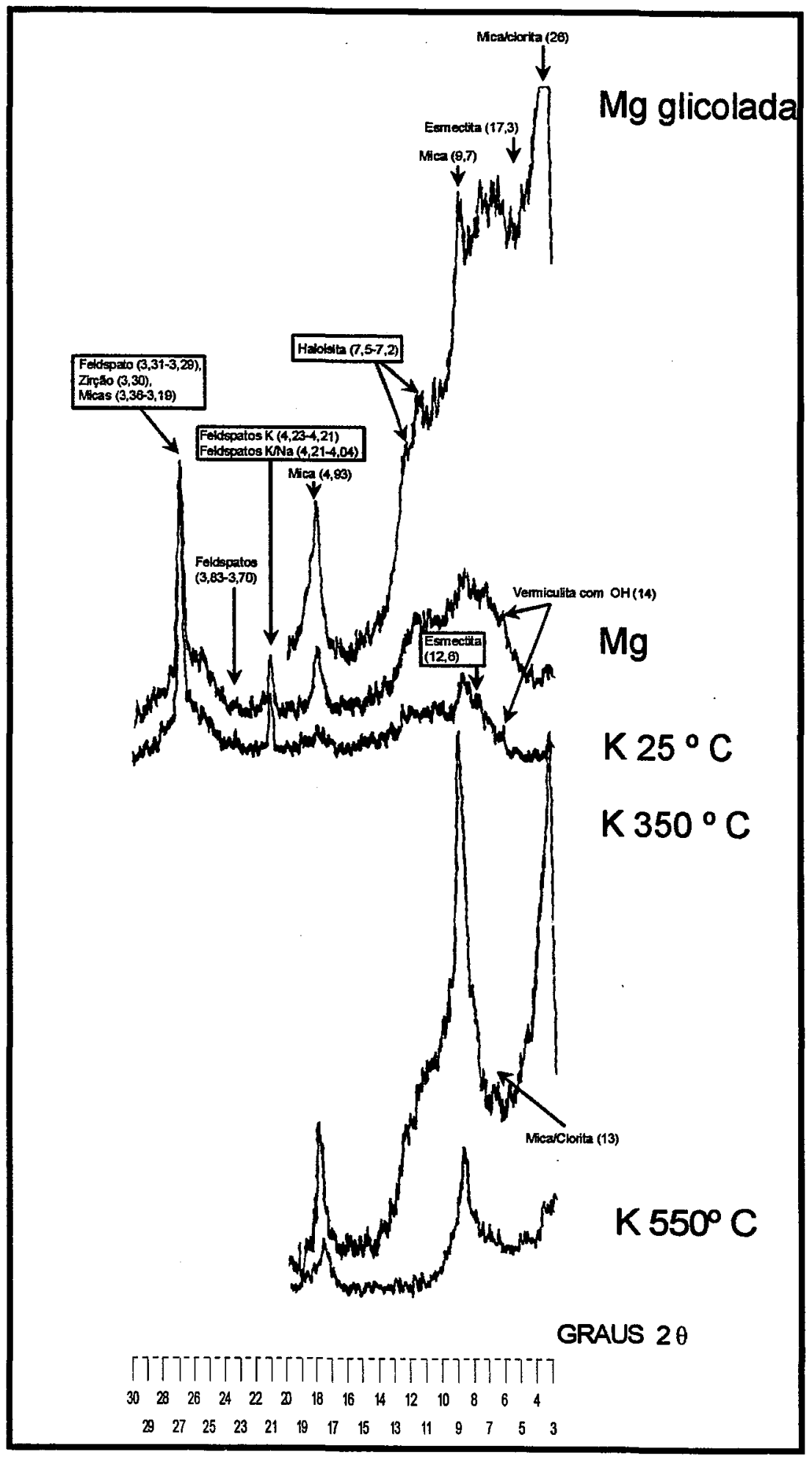

Figura 54 - Difração de raios $X$ da fração argila do horizonte Btgf $(75 \mathrm{~cm})$ do perfil 4. 


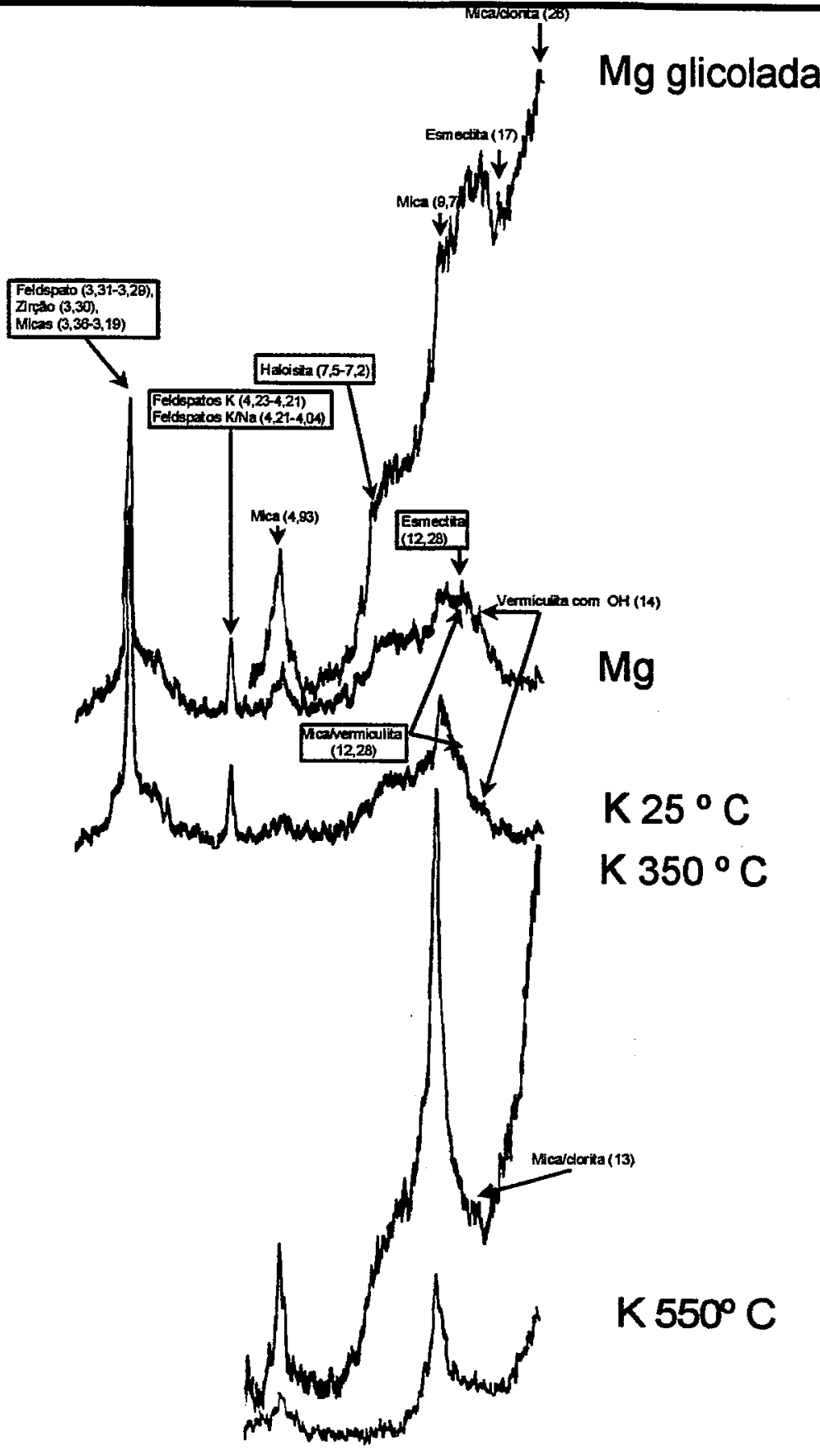

GRAUS $2 \theta$

$\begin{array}{llllllllllllll}30 & 8 & 26 & 24 & 22 & 20 & 18 & 16 & 14 & 12 & 10 & 8 & 6 & 4\end{array}$

$\begin{array}{llllllllllllll}29 & 27 & 25 & 23 & 21 & 19 & 17 & 15 & 13 & 11 & 9 & 7 & 5 & 3\end{array}$

Figura 55 - Difração de raios $X$ da fração argila da camada $B C t g v(140 \mathrm{~cm})$ do perfil 4. 


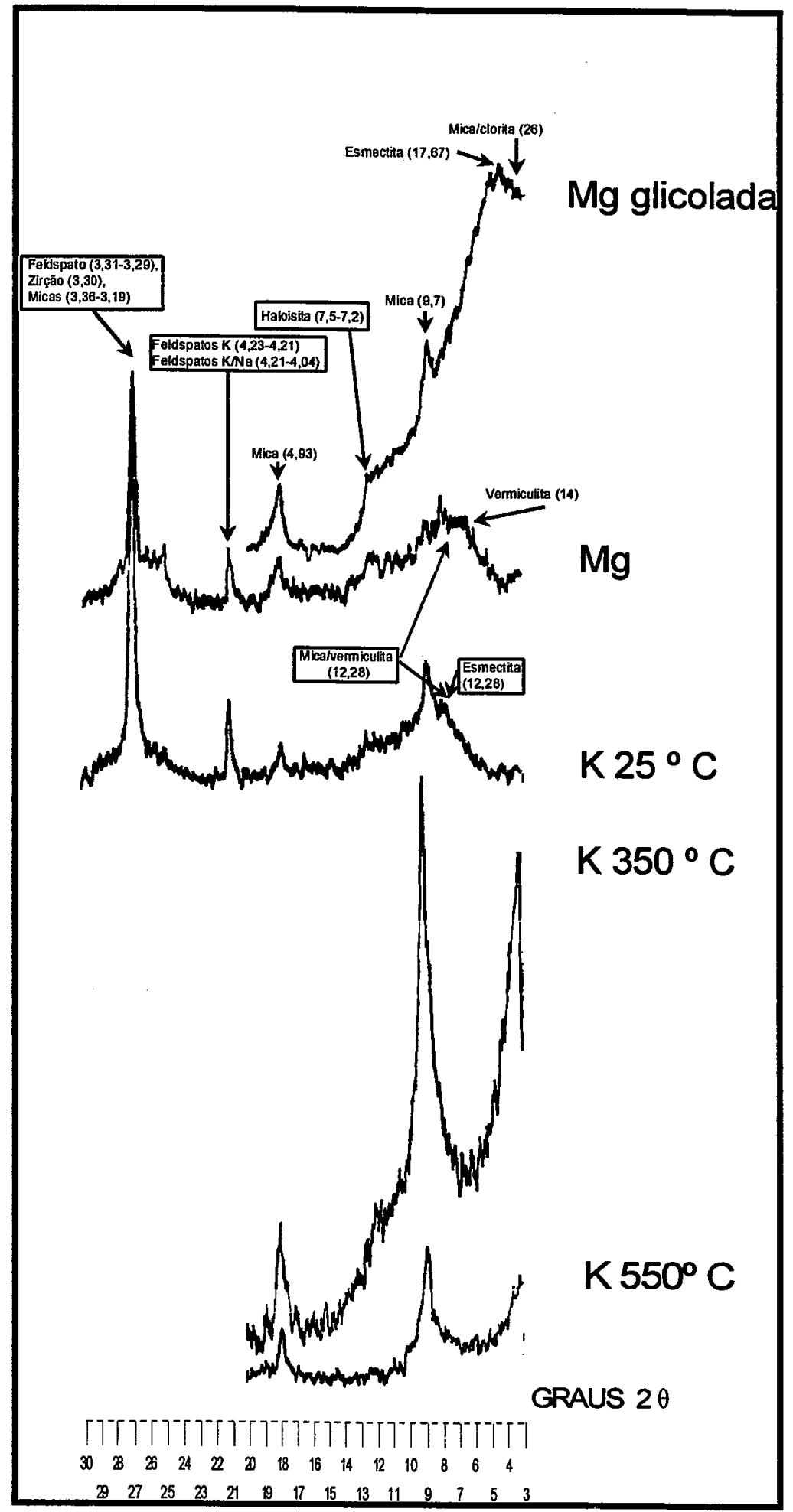

Figura 56 - Difração de raios $X$ da fração argila da camada $C r$ (180-195 cm) do perfil 4. 


\subsection{Perfil 1}

$\mathrm{O} \mathrm{pH}$ em $\mathrm{H}_{2} \mathrm{O}$ varia de alcalino a ligeiramente ácido (6.6 a 7.4), com os teores de $\mathrm{Ca}^{2+} \mathrm{e} \mathrm{Mg}^{2+}$ muito elevados, com relação de 3-4:1, o teor de $\mathrm{K}^{+}$varia de alto no Ap e baixo nos demais horizontes e os de $\mathrm{P}_{2} \mathrm{O}_{5}$ de médio no Ap a baixo nos demais horizontes. A saturação por bases, devido a estes teores, é alta. A CTC $_{7}$ (16.7 a 11.2 $\mathrm{cmol}_{\mathrm{c}} \cdot \mathrm{Kg}^{-1}$ de solo) sugere minerais do tipo caulinita são os argilominerais dominantes (no caso haloisita).

\subsection{Perfil 2}

$\mathrm{O} \mathrm{pH}$ em água varia de ácido a ligeiramente ácido em profundidade (5.4 a

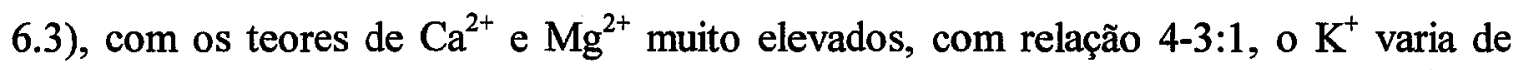
baixo a muito baixo no Ap até médio em profundidade e o $\mathrm{P}_{2} \mathrm{O}_{5}$ é muito baixo em todo o perfil. A saturação por bases é alta. $\mathrm{A} \mathrm{CTC}_{7}$ variando de 10,9 a $17,11 \mathrm{cmolc}^{-\mathrm{Kg}^{-1}}$ de solo, sugere minerais do tipo caulinita com argilominerais dominantes.

\subsection{Perfil 3}

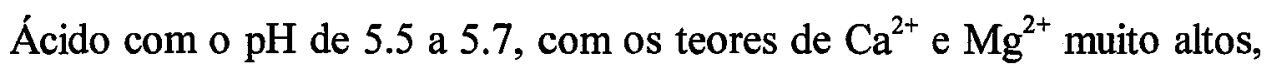
mantendo uma relação 4-3:1, o teor de $\mathrm{K}^{+}$varia de médio no Ap, passando de baixo a muito baixo, com elevação a médio em profundidade. $\mathrm{O}$ teor de $\mathrm{P}_{2} \mathrm{O}_{5}$ é baixo no Ap, passando a muito baixo em profundidade. A saturação por bases varia de $64 \%$ a $49 \%$, com $37 \%$ em Btgl. $\mathrm{A} \mathrm{CTC}_{7}$, variando de 9.80 a $14.50 \mathrm{cmol}_{\mathrm{c}} \cdot \mathrm{Kg}^{-1}$ de solo, indica minerais do tipo caulinita como argilominerais dominantes.

\subsection{Perfil 4}

Com maior variação de $\mathrm{pH}$ dos perfis estudados, indo de ácido à fortemente ácido, atingindo a neutralidade novamente nos volumes de alteritas. Os teores de $\mathrm{Ca}^{2+}$ e $\mathrm{Mg}^{2+}$, mantêm-se elevados, com os teores $\mathrm{K}^{+}$variando de baixos a médios em profundidade e os teores de $\mathrm{P}_{2} \mathrm{O}_{5}$ variando de médios a muito baixos em profundidade. 


\subsubsection{Análise do ataque sulfúrico}

$\mathrm{Na}$ figura 57 os volumes pedológicos demonstram uma tendência de diminuição dos valores de $\mathrm{SiO}_{2}$ e redução maior dos valores de $\mathrm{Al}_{2} \mathrm{O}_{3}$ até o perfil 3, em direção a jusante, com conseqüente Ki médio de 2,31 no perfil 1 e 2,74 no perfil 2 e 2,56 no perfil 3. Os valores de Ki dos horizontes A e B são próximos da média para os perfis 1 e 2, com contraste maior no perfil 3 com a média de Ki do horizonte A de 2,41 e de $\mathrm{B}$ de 2,85 . No perfil 4 há uma elevação dos valores de $\mathrm{SiO}_{2}$ e uma pequena elevação dos valores de $\mathrm{Al}_{2} \mathrm{O}_{3}$, resultando em valores médios de $\mathrm{Ki}$ de 3,01 , com elevação do contraste entre A com Ki de 3,24 e B de 2,86. Verticalmente os perfis apresentam um contraste crescente dos valores $\mathrm{SiO}_{2}$ e $\mathrm{Al}_{2} \mathrm{O}_{3}$ em direção a jusante. $\mathrm{O}$ surgimento de horizontes mais expressivos de perda entre o Ap e $\mathrm{Bt}$ nos perfis 2, 3 e 4 reduzem os valores de $\mathrm{SiO}_{2}$ mais acentuadamente do que o de $\mathrm{Al}_{2} \mathrm{O}_{3}$, resultando em $\mathrm{Ki}$ de 2,01 no horizonte $\mathrm{BA}$ do perfil 2, de 2.02 no horizonte $\mathrm{AE}$ do perfil 3 e 2.66 no horizonte $\mathrm{E}$ do

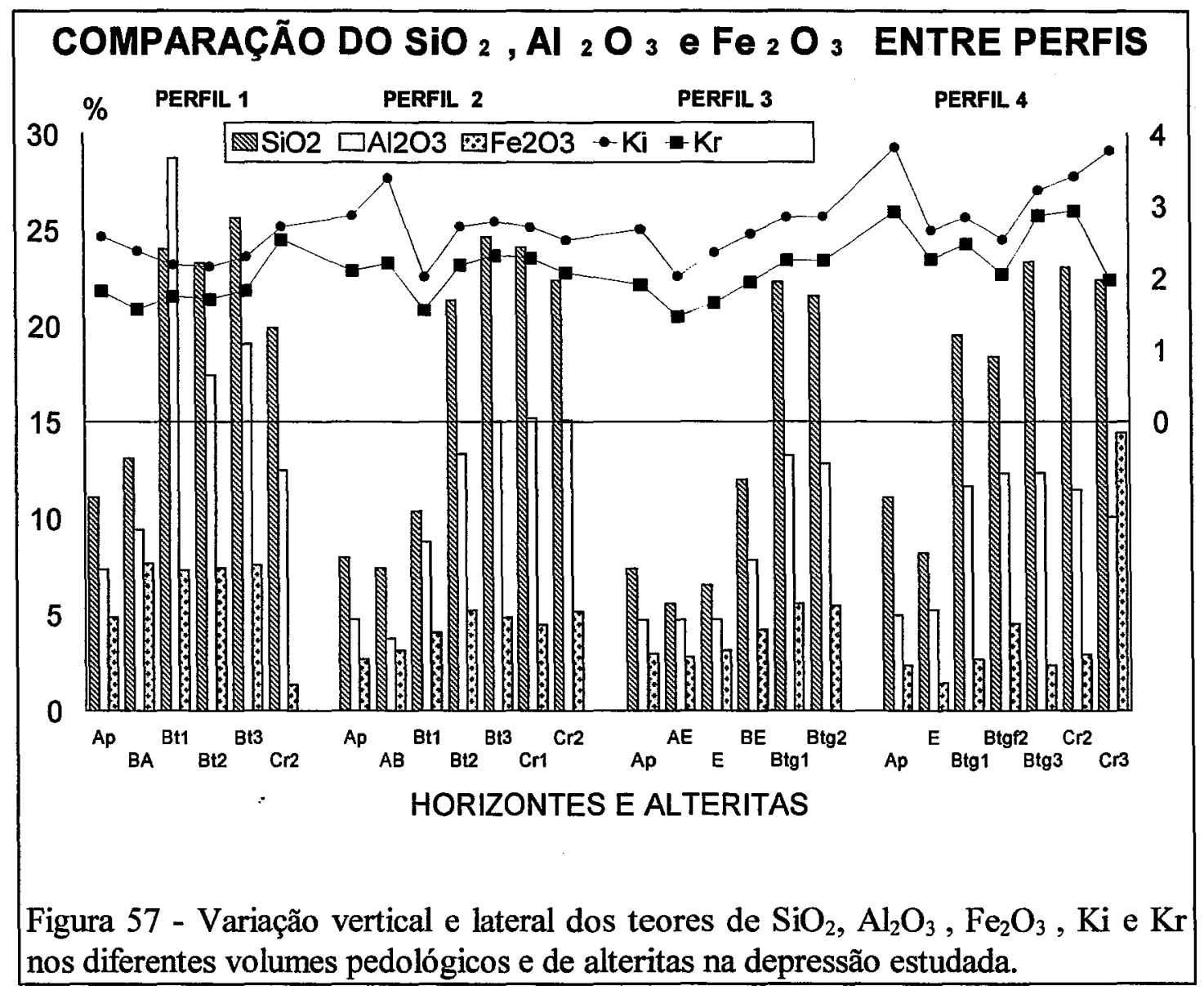


perfil 4.

Os teores de $\mathrm{Fe}_{2} \mathrm{O}_{3}$ são decrescente em direção a jusante. Nos perfis 2 e 3 os valores são semelhantes, no perfil 4 os valores são menores, mostrando claramente o aumento da hidromorfia e o aumento da ferrólise, com os ciclos sucessivos de redução do $\mathrm{Fe}^{3+}$ para $\mathrm{Fe}^{2+}$, com perda em solução do ferro nos volumes pedológicos e a crescente acumulação de ferro nos volumes de alteração.

Os valores de $\mathrm{TiO}_{2}$ (não mostrados) são aproximadamente constantes na toposseqüência, com pequena variação vertical, com mais uma indicação da semelhança litológica vertical e lateral, dos sedimentos que deram origem aos volumes pedológicos.

\subsection{Mapeamento de deformações e taxa de mergulho do banco de calcário basal, do pacote de sedimentos, alteritas e solos nas pedreiras}

\subsubsection{Taxas de "mergulho"}

A estratificação do material de origem permitiu acompanhar diferenças no nível do banco de calcário basal e da camada rítmica de sedimentos, situada acima deste banco, seguida pelas alteritas e solos, em pedreiras próximas e a sua relação com o relevo. Mapeou-se com o teodolito o banco de calcário basal na pedreira a Nordeste a aproximadamente $600 \mathrm{~m}$ da depressão estudada (figuras 59, 60 e 61), a montante da toposseqüência, constatando-se que, nos 140 metros medidos, o banco de calcário e todo o pacote de sedimentos, alteritas e solos sobrepostas "mergulham" 2,70 m. Na pedreira a $150 \mathrm{~m}$ a oeste (figuras 58 a 65), em uma exposição paralela à toposseqüência estudada, os sedimentos não apresentaram variação significativa de nível nos 80 metros medidos, e a noroeste, a 100 metros a jusante do perfil 4 , os sedimentos iniciam uma ascensão de $1,20 \mathrm{~m}$ nos 50 metros medidos. As medidas e observações realizadas permitiram constatar mudanças no nível de base nas diferentes exposições medidas, correlacionadas positivamente com as diferenças no relevo.

Os sedimentos mais conservados acima do banco de calcário basal apresentam expansão das camadas de forma crescente e homogênea horizontalmente, em direção à superficie. As alteritas e solos logo acima dos sedimentos mais preservados, 
apresentaram diferenças em expansão, que foram acompanhadas pelo relevo. A dificuldade de acompanhar volumes-guias dentro destes volumes com o teodolito, não permitiu descartar um processo erosivo diferenciado dos sedimentos mais alterados, que explicasse a diferenciação do relevo. 


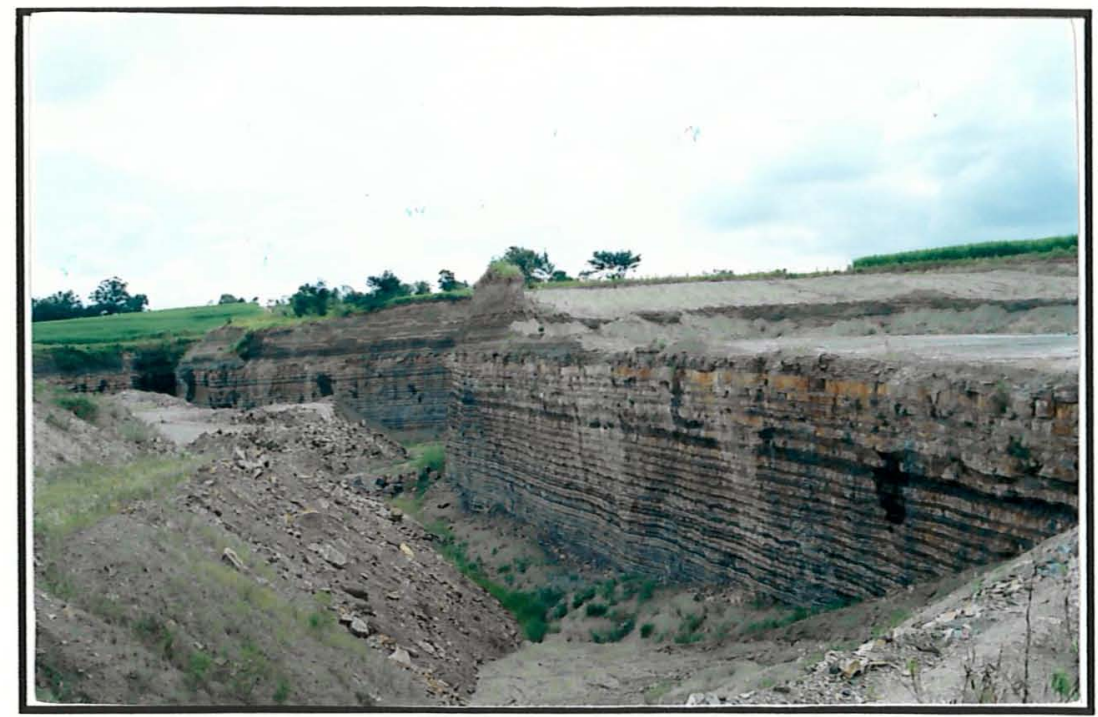

Figura 58 - Vista geral de pedreira de extração de calcário NE-LE, a montante da depressão estudada, com grande homogeneidade na estratificação do calcário, típico da Formação Iratí, podendo-se acompanhar por centenas de metros a estratificação.

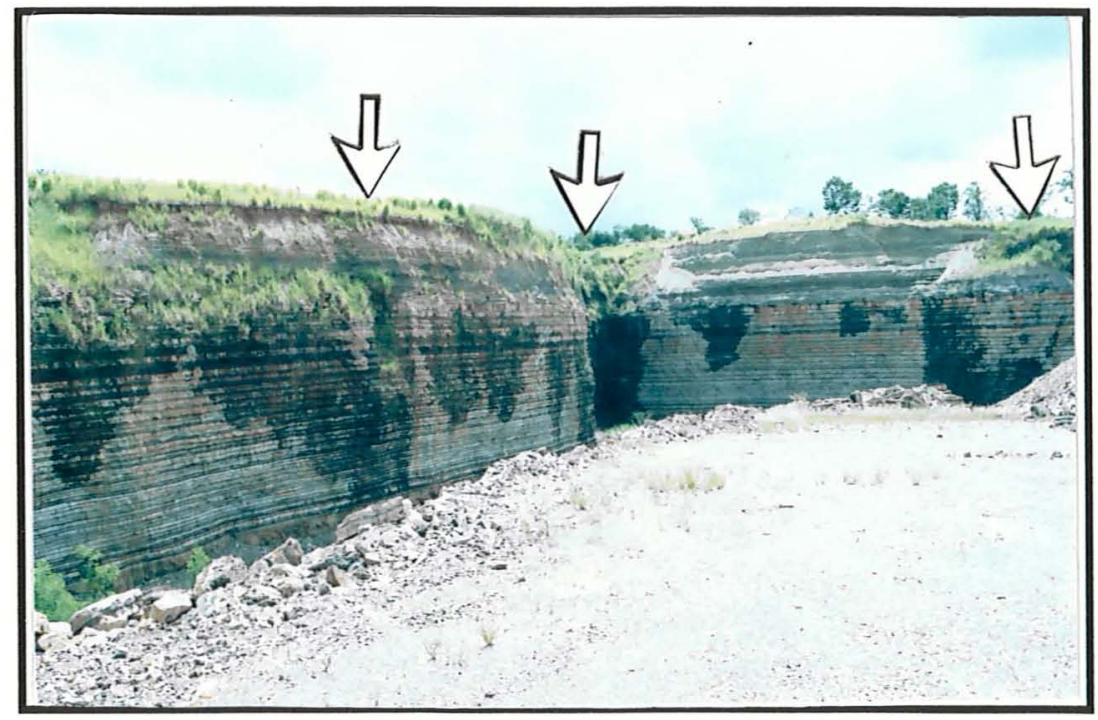

Figura 59 - Corte geológico recém aberto, medido em pedreira à NELE, a montante da depressão estudada, neste corte mediu-se (setas brancas) a taxa de "mergulho" da Formação Irati, a espessura do pacote de sedimentos e de alteritas mais solos. 


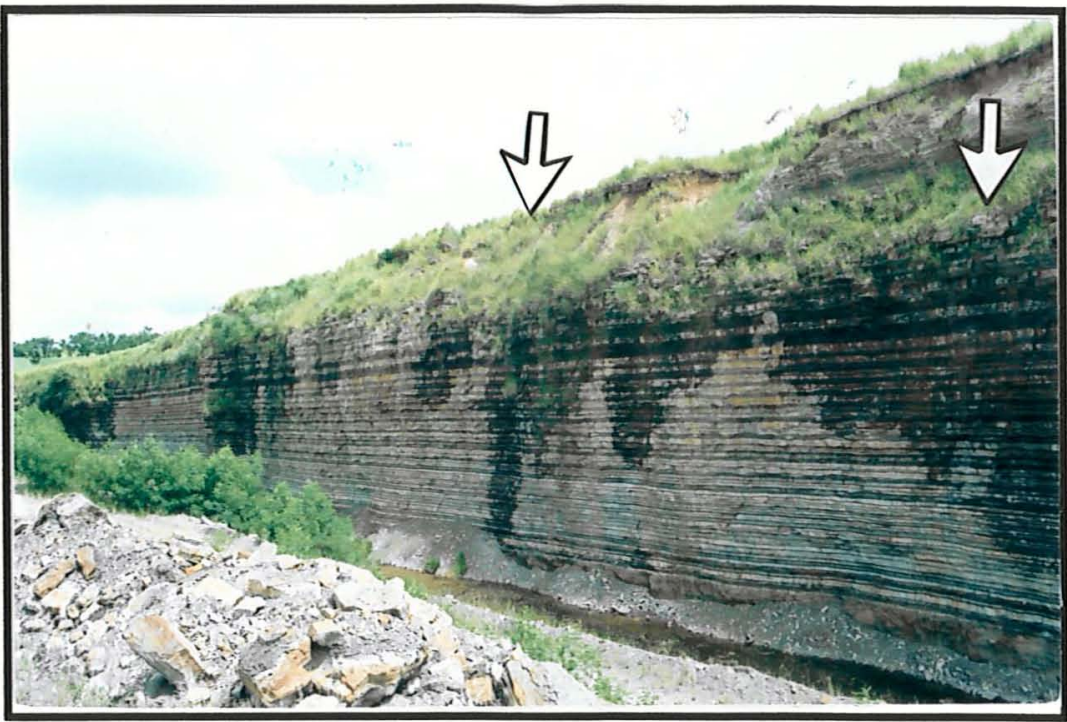

Figura 60 - Corte geológico recém aberto, medido (setas brancas) em pedreira NE-LE, a montante da depressão estudada.

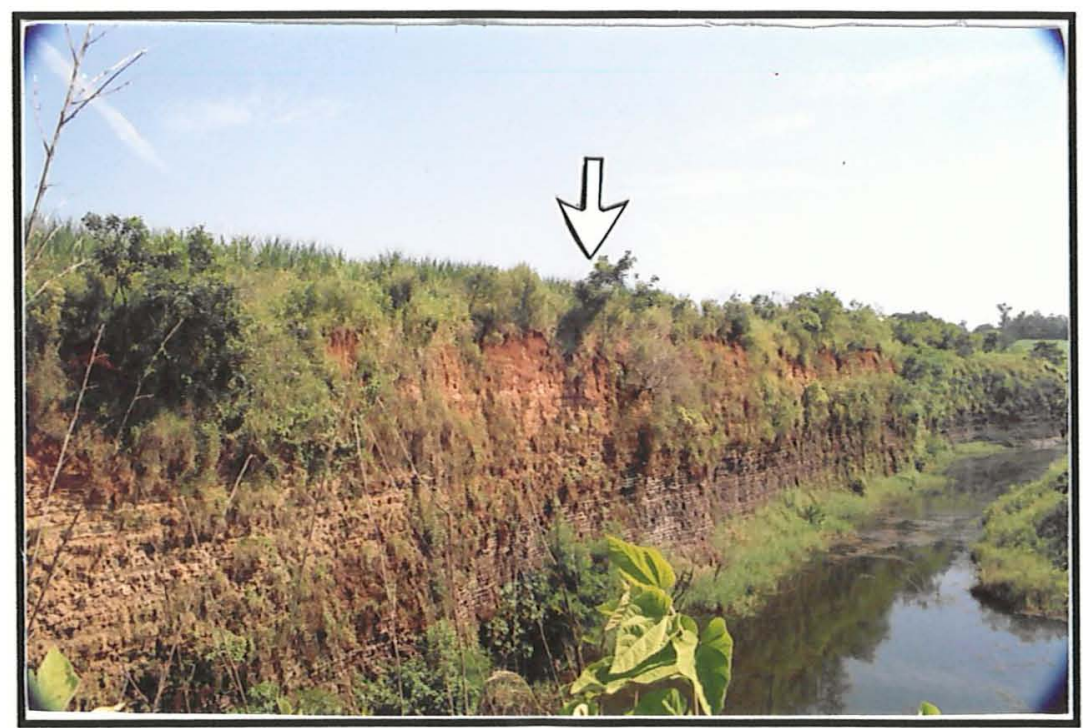

Figura 61 - Corte geológico antigo à leste, a montante da depressão, próximo ao perfil 1 (seta branca) no topo da depressão estudada, que foi medido precariamente. A espessura estimada medida com trena, próximo ao perfil 1, do solo mais alteração é de 8 metros. 


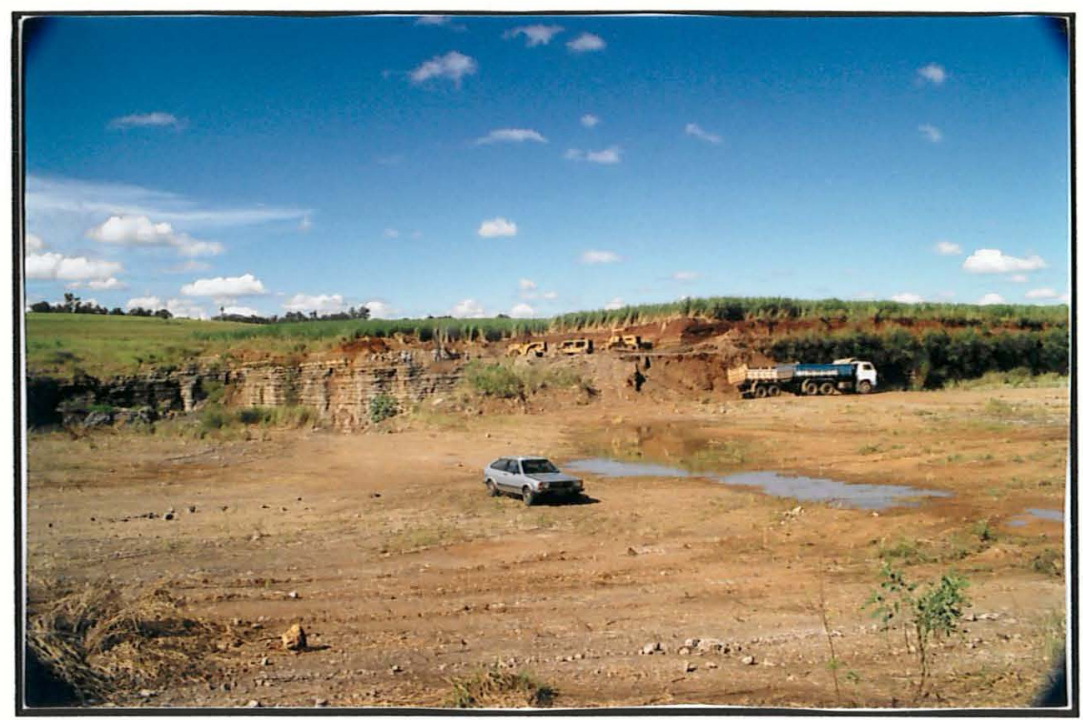

Figura 62 - Visão geral da pedreira com cortes geológicos paralelos e a oeste da toposseqüência, estudada.

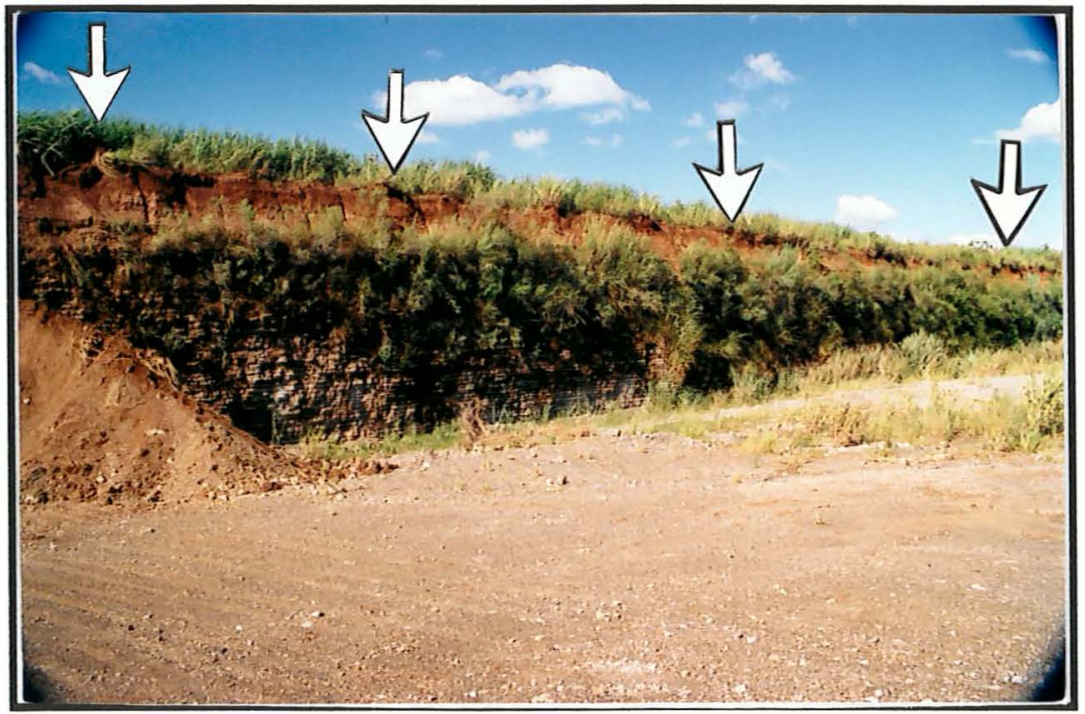

Figura 63 - Detalhe mais próximo de corte mais antigo, paralelo a toposseqüência estudada, com quatro pontos medidos (seta brancas), indicando que os sedimentos, alteritas e solos estão paralelos e planos. $O$ solo e as alteritas somadas tem espessura de 7,30 metros. 


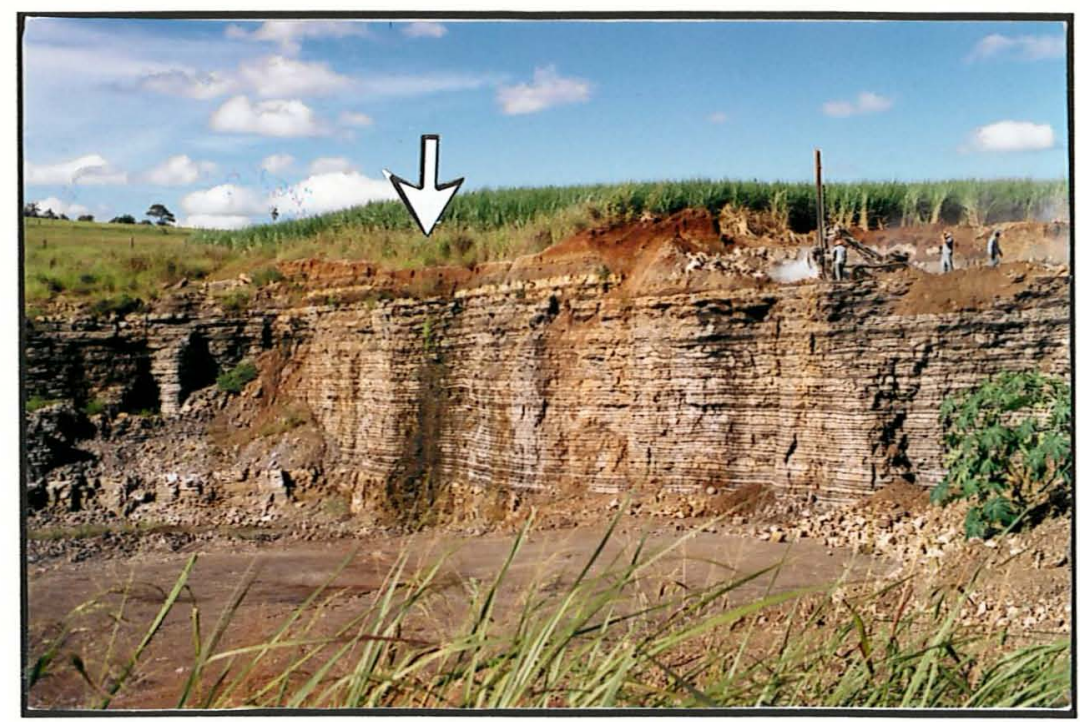

Figura 64 - Corte geológico recém aberto a oeste da toposseqüência, com dreno simples da depressão estudada no centro (seta branca).

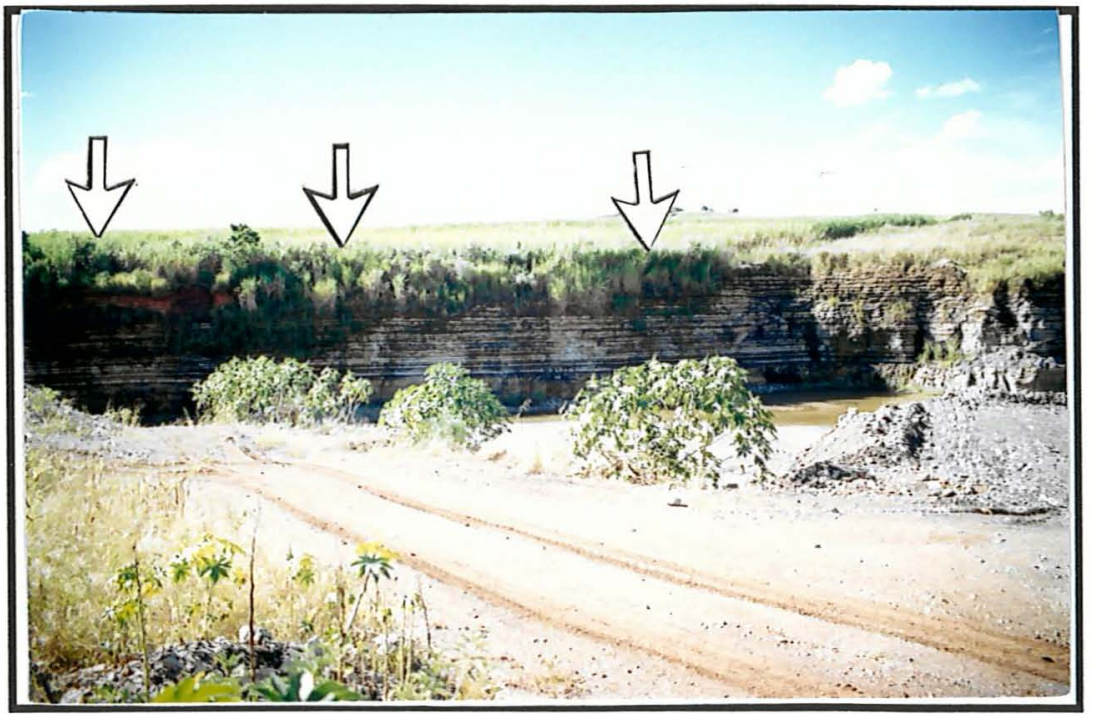

Figura 65 - Detalhe de corte geológico recém aberto, no sentido da toposseqüência estudada a oeste da depressão, com 3 pontos medidos (setas brancas), onde constata-se a elevação do pacote de sedimentos, alteritas e solos. A soma da espessura do volume de solo e alteritas é de $3,40 \mathrm{~m}$, considerando ponto mais a esquerda, mais preservado da erosão e ou mineração. 


\subsubsection{Deformações do terreno pela expansão diferenciada dos sedimentos}

Nos pacotes de sedimentos medidos não foram constatadas diferenças na expansão dos sedimentos mais consolidados, embora em exposições mais "sujas" e de acesso, mais dificil tem-se a impressão que ocorrem.

A observação mais cuidadosa dentro de perfis profundos de solos e exposições geológicas mais limpas foram a seguir investigados.

\subsection{Morfologia das alteritas na base das trincheiras da depressão estudada}

A sucessão rítmica de folhelhos pirobetuminosos e calcários dolomíticos observados nos sedimentos da Formação Irati nas pedreiras próximas concorda com Amaral (1971). Nas alteritas com boa drenagem (figura 66) o folhelho pirobetuminoso conserva a coloração preta, com bonecas de sílex e lâminas mais grosseiras; os volumes amarelo-avermelhados possuem normalmente lâminas de sílex mais finas (milimétricas) e parecem ser volumes reliquiais do calcário dolomítico com lâminas milimétricas de sílex. As lâminas centimétricas de silex negro degradam-se, em padrão de desfolhamento em volumes amarelados na parte superior a marrom escuro na base, com fragmentos de sílex negro em seu interior. Estes volumes, principalmente as lâminas milimétricas e centimétricas serviram como volumes guia, mapeados em todas as trincheiras. 


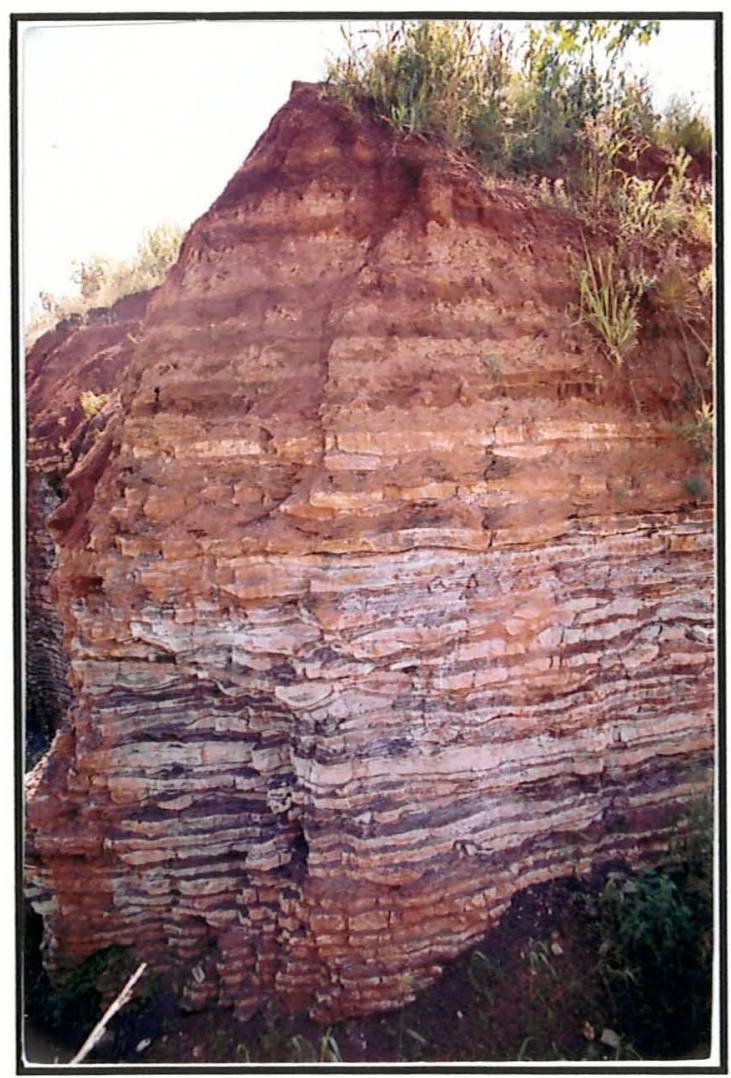

Figura 66 - Corte geológico recém aberto paralelo a toposseqüência estudada mostrando o padrão de alteração típico de alteritas bem drenadas da Formação Irati.

Acompanhando-se o hidromorfismo, associado ao impedimento da drenagem na base dos perfis 3 e 4, com perda de Fe e Si em solução dos solos, as cores dos volumes pedológicos evoluíram de amarelo-avermelhado ao surgimento crescente das cores neutras de redução em direção ao centro da depressão. As cores das alteritas com a formação de volumes esverdeados para azulados e azulados nos volumes de alteração seguiu a diferenciação pedológica em direção as cores neutras. Os domínios azulados das alteritas, indicam uma possível formação in situ de minerais do tipo nontronitas, em um meio rico em Fe e $\mathrm{Si}$ em solução, no caso provavelmente beidelitas ferriferas. 


\subsubsection{Alteritas do Perfil 1}

As alteritas apresentam-se onduladas e inclinadas, sendo que se sucedem volumes com fundo mais preto com volumes vermelho-amarelados, com aumento da nitidez e separação das alteritas em profundidade. $\mathrm{O}$ quadro 2 sintetiza as principais informações obtidas.

Quadro 2. Principais características das alteritas do perfil 1.

\begin{tabular}{|c|c|c|c|c|}
\hline Volume & $\begin{array}{l}\text { Prof } \\
(\mathbf{c m})\end{array}$ & Cor & $\begin{array}{l}\text { Lâminas, leitos ou bonecas } \\
\text { de sílex }\end{array}$ & Observações \\
\hline $1^{\circ}$ & $130-158$ & $\begin{array}{l}\text { preto } \\
\text { difuso }\end{array}$ & 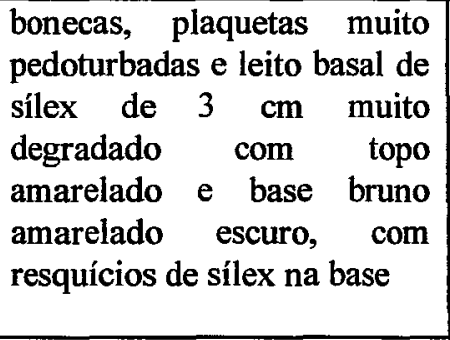 & $\begin{array}{l}\text { volume muito ondulado e } \\
\text { inclinado, tomando parte } \\
\text { basal do último horizonte, as } \\
\text { bonecas e plaquetas da parte } \\
\text { superior conservam } \\
\text { revestimento preto, em } \\
\text { massa de solo bruno } \\
\text { avermelhado escuro }\end{array}$ \\
\hline $2^{\circ}$ & $158-168$ & avermelhado & $\begin{array}{l}\text { lâminas milimétricas e } \mathrm{cm} \\
\text { com leito de sílex de } 1 \mathrm{~cm} \text { na } \\
\text { base }\end{array}$ & \\
\hline $3^{\circ}$ & $168-191$ & preto & $\begin{array}{l}\text { leito de alterado de sílex de } 4 \\
\mathrm{~cm} \text { na base com padrão } \\
\text { semelhante ao do volume } 1\end{array}$ & \\
\hline $4^{\circ}$ & $191-203$ & $\begin{array}{l}\text { avermelhado para } \\
\text { róseo }\end{array}$ & $\begin{array}{l}\text { avermelhado e róseo } \\
\text { esbranquiçado associado à } \\
\text { lâminas milimétricas de } \\
\text { sílex, leito de sílex alterado } \\
\text { de } 1 \mathrm{~cm} \text { a } 196 \mathrm{~cm}\end{array}$ & \\
\hline $5^{\circ}$ & $203-213$ & preto & $\begin{array}{l}\text { sem resquícios de lâminas e } \\
\text { fragmentos de silex. }\end{array}$ & \\
\hline $6^{\circ}$ & $213-228$ & $\begin{array}{l}\text { avermelhado para } \\
\text { róseo }\end{array}$ & topo e base muito amarelos & \\
\hline $7^{\circ}$ & $228-243$ & preto & $\begin{array}{l}\text { com leito de } 3-4 \mathrm{~cm} \text { muito } \\
\text { alterado na base com topo } \\
\text { amarelado, indo para bruno } \\
\text { escuro com resquícios de } \\
\text { sílex cinza escuro de } 3 \mathrm{~cm} \\
\text { na base }\end{array}$ & \\
\hline $8^{\circ}$ & $243-268$ & $\begin{array}{l}\text { avermelhado para } \\
\text { róseo }\end{array}$ & $\begin{array}{l}\text { lâminas milimétricas } \\
\text { semelhantes volume } 4\end{array}$ & \\
\hline
\end{tabular}




\subsubsection{Alteritas do Perfil 2}

Os volumes são planos e horizontais, a transição com o meio hidromórfico, introduz as cores neutras, rosadas, esverdeadas e azuladas nos volumes de alteração. A estratificação reliquial de folhelhos e calcário se mantém. O quadro 3 apresenta as principais observações realizadas.

Quadro 3. Principais características das alteritas do perfil 2.

\begin{tabular}{|c|c|c|c|c|}
\hline Volume & $\begin{array}{l}\text { Prof } \\
\text { (cm) }\end{array}$ & Cor & $\begin{array}{l}\text { Lâminas, leitos ou bonecas } \\
\text { de silex }\end{array}$ & Observações \\
\hline $1^{\circ}$ & $140-155$ & $\begin{array}{l}\text { preto residual em } \\
\text { fundo } \\
\text { avermelhado, com } \\
\text { amarelado na base }\end{array}$ & bonecas e plaquetas de sílex & $\begin{array}{l}\text { topo do volume mais preto e } \\
\text { base com fragmentos se } \\
\text { alterando em fundo mais } \\
\text { amarelado }\end{array}$ \\
\hline $2^{\circ}$ & $155-172$ & preto & leito de silex de $2 \mathrm{~cm}$ na base & \\
\hline $3^{\circ}$ & $172-185$ & $\begin{array}{l}\text { avermelhado no } \\
\text { topo indo para } \\
\text { amarelado na base }\end{array}$ & $\begin{array}{l}\text { leito de sílex a } 1 \mathrm{~cm} \text { a } 184 \\
\mathrm{~cm} \text { de profundidade }\end{array}$ & \\
\hline $4^{\circ}$ & $185-193$ & $\begin{array}{l}\text { cinza indo para } \\
\text { azulado }\end{array}$ & $\begin{array}{lll}\text { lâminas de } & \text { sílex } \\
\text { subcentimétrica } & \text { por } & \text { todo } \\
\text { volume } & & \\
& & \end{array}$ & \\
\hline $5^{\circ}$ & $193-204$ & amarelado & vários níveis de lâminas & \\
\hline $6^{\circ}$ & 204215 & preto & $\begin{array}{l}\text { fragmentos de sílex por todo } \\
\text { o volume, mais conservado } \\
\text { na base }\end{array}$ & $\begin{array}{l}\text { volume todo talvez fosse um } \\
\text { leito de } 10 \mathrm{~cm} \text { de sílex. }\end{array}$ \\
\hline $7^{\circ}$ & $220-229$ & $\begin{array}{l}\text { avermelhado com } \\
\text { manchas azuladas }\end{array}$ & $\begin{array}{l}\text { lâminas milimétricas de } \\
\text { sílex associados a domínios } \\
\text { avermelhados e azulados }\end{array}$ & \\
\hline $8^{\circ}$ & $229-240$ & preto & $\begin{array}{l}\text { leito centimétrico muito } \\
\text { alterado na base }\end{array}$ & \\
\hline
\end{tabular}




\subsubsection{Alteritas do Perfil 3}

O quadro 4 apresenta as principais observações encontradas nas alteritas do perfil 3.

Quadro 4. Principais observações nas alteritas do perfil 3.

\begin{tabular}{|c|c|c|c|c|}
\hline Volume & $\begin{array}{l}\text { Prof } \\
\text { (cm) }\end{array}$ & Cor & $\begin{array}{l}\text { Lâminas, leitos ou bonecas } \\
\text { de sílex }\end{array}$ & Observações \\
\hline $1^{\circ}$ & $140-145$ & preto & & $\begin{array}{l}\text { volume sendo envolvida pelo } \\
\text { volume superior }\end{array}$ \\
\hline $2^{\circ}$ & $145-152$ & amarelo & $\begin{array}{l}\text { camada com concentração de } \\
\text { plaquetas e bonecas, com } \\
\text { lâmina de silex muito } \\
\text { degradada a } 146 \mathrm{~cm} \text {. }\end{array}$ & \\
\hline $3^{\circ}$ & $152-173$ & preto & $\begin{array}{llr}\text { leito de silex de } & 3 \mathrm{~cm} \text { a } & 173 \\
\text { de profundidade } & \text { se } \\
\text { degradando } & \text { com } & \text { topo } \\
\text { amarelado e } & \text { base } & \text { bruno } \\
\text { escuro } & & \\
\end{array}$ & \\
\hline $4^{\circ}$ & $173-187$ & $\begin{array}{l}\text { amarelo } \\
\text { avermelhado com } \\
\text { fundo acinzentado } \\
\text { azulado }\end{array}$ & $\begin{array}{l}\text { leito de sílex de } 1 \mathrm{~cm} \text { a } 187 \\
\mathrm{~cm} \text { na base se fragmentando }\end{array}$ & \\
\hline $5^{\circ}$ & $187-210$ & $\begin{array}{l}\text { azulado com } \\
\text { manchas } \\
\text { amareladas } \\
\end{array}$ & $\begin{array}{l}\text { vários níveis de lâminas } \\
\text { milimétricas }(196,200 \mathrm{~cm} \text { e } \\
\text { outras) }\end{array}$ & \\
\hline $6^{\circ}$ & $210-225$ & amarelo brunado & $\begin{array}{l}\text { fragmentos de sílex por todo } \\
\text { o volume e volume bruno } \\
\text { escuro de sílex na base com } \\
\text { resquícios de sílex. Laje } \\
\text { original talvez com } 15 \mathrm{~cm} \text { de } \\
\text { espessura }\end{array}$ & \\
\hline $7^{\circ}$ & $225-238$ & $\begin{array}{l}\text { azulado com } \\
\text { manchas } \\
\text { amareladas } \\
\end{array}$ & $\begin{array}{l}\text { vários níveis de lâminas, } \\
\text { semelhante ao } 5^{\circ} \text { volume }\end{array}$ & \\
\hline $8^{\circ}$ & $238-+$ & $\begin{array}{l}\text { amarelo brunado } \\
\text { indo na base para } \\
\text { cinza brunado }\end{array}$ & $\begin{array}{l}\text { laje ou leito cinza escuro } \\
\text { seca sob volume muito } \\
\text { úmido }\end{array}$ & $\begin{array}{l}\text { impenetrável com vanga ou } \\
\text { picareta. }\end{array}$ \\
\hline
\end{tabular}




\subsubsection{Alteritas do Perfil 4}

Devido ao processo de alteração mais avançado em relação ao outros perfis a separação de volumes mais nítidos próximo a transição com o solo foi muito dificil, sendo que a lateralidade foi estabelecida basicamente pelos volumes guias de sílex. O quadro 5 apresenta as principais características das alteritas do perfil 4.

Quadro 5. Principais características das alteritas do perfil 4.

\begin{tabular}{|c|c|c|c|c|}
\hline Volume & $\begin{array}{l}\text { Prof } \\
(\mathrm{cm})\end{array}$ & Cor & Lâminas, leitos ou bonecas de sílex & Observaçōes \\
\hline $1^{\circ}$ & $165-170$ & preto & $\begin{array}{l}\text { base com leito de sílex se degradando } \\
\text { em padrão típico já observado } \\
\text { anteriormente com } 4 \mathrm{a} 5 \mathrm{~cm}\end{array}$ & \\
\hline $2^{\circ}$ & $175-178$ & $\begin{array}{l}\text { preto descontínuo } \\
\text { entremeado por } \\
\text { volume amarelo } \\
\text { brunado inferior } \\
\end{array}$ & & \\
\hline $3^{\circ}$ & $178-182$ & $\begin{array}{l}\text { amarelo brunado } \\
\text { entremeados por } \\
\text { volumes pretos dos } \\
\text { volumes } \\
\text { adjacentes, tanto } \\
\text { acima como abaixo }\end{array}$ & & \\
\hline $4^{\circ}$ & $182-198$ & preto azulado & $\begin{array}{l}\text { níveis de lâminas de sílex com até } 1 \\
\mathrm{~cm} \text { de espessura a } 183,187 \text { e } 192 \mathrm{~cm} \text {. }\end{array}$ & \\
\hline $5^{\circ}$ & $198-202$ & amarelo brunado & $\begin{array}{l}\text { leito de sílex de } 4 \mathrm{~cm} \text { se degradando } \\
\text { de amrelo a cinza amarelado na base. }\end{array}$ & \\
\hline $6^{\circ}$ & $202-208$ & azul esverdeado & $\begin{array}{l}\text { vários níveis de lâminas milimétricas } \\
\text { de silex }\end{array}$ & \\
\hline $7^{\circ}$ & $208-216$ & $\begin{array}{l}\text { azul esverdeado } \\
\text { mais claro, com } \\
\text { manchas } \\
\text { amareladas } \\
\text { brunados isoladas }\end{array}$ & $\begin{array}{l}\text { vários níveis de lâminas milimétricas } \\
\text { até } \mathrm{cm} \text {. }\end{array}$ & \\
\hline $8^{\circ}$ & $216-225$ & 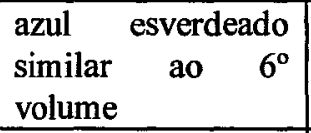 & $\begin{array}{l}\text { vários níveis de lâminas milimétricas } \\
\text { de sílex }\end{array}$ & \\
\hline $9^{\circ}$ & $220-225$ & $\begin{array}{l}\text { azul amarelo indo } \\
\text { a amarelado } \\
\text { brunado na base }\end{array}$ & lâminas milimétricas de sílex na base & \\
\hline $10^{\circ}$ & $225-233$ & $\begin{array}{l}\text { volume } \\
\text { brunado }\end{array}$ & $\begin{array}{l}\text { leito de } 4 \text { a } 5 \mathrm{~cm} \text { de espessura bruno } \\
\text { escuro, se desmanchando em folhas } \\
\text { muito úmido, com base cinza escuro } \\
\text { seca }\end{array}$ & $\begin{array}{l}\text { impenetrável com } \\
\text { vanga ou picareta. }\end{array}$ \\
\hline
\end{tabular}


Assim como nos volumes de alteração de cortes geológicos puderam ser ligados por centenas de metros, na base dos perfil seguiu-se, basicamente, 3 leitos de sílex de espessura variando de 2 a $4 \mathrm{~cm}$, que podem ser unidos lateralmente, a aproximadamente $170 \mathrm{~cm}, 200 \mathrm{~cm}$ e $235 \mathrm{~cm}$. Esta ligação foi acompanhada dos volumes de alteração: preto, amarelo brunado-bruno escuro e preto a amarelo brunado-bruno escuro. Apesar de o perfil 1 não apresentar leito de sílex a aproximadamente $2 \mathrm{~m}$, o volume preto nesta profundidade associa-se a um volume muito amarelo no topo do próximo volume, que pode ser o resquício final da alteração do leito de sílex.

A recomposição lateral dos volumes de alteração, com auxilio dos volumes guias de sílex, indicam que existe continuidade horizontal geológica, afastando diferenciações litológicas mais pronunciadas que expliquem a diferenciação de solos. Ao mesmo tempo, esta lateralidade nas alteritas reforçam a hipótese de dobramentos atectônicos, com estabelecimento de uma hidromorfia e ou afundamento geoquímico secundários associados, e a diferenciação lateral do solo a partir disto.

\subsection{Evidências dos principais mecanismos e processos atuantes na} formação das depressões e diferenciação de solos

As evidências de formação das depressões e o processo de diferenciação pedológica associada estão principalmente no campo, sendo que a micromorfologia dos solos permite acompanha a diferenciação pedológica na escala microscópica. Este tipo de estudo, devido à sua complexidade, envolveria um estudo de geologia estrutural, macro e micromorfológico de alteração de rochas. Pode-se, no entanto, pelo trabalho realizado, descartar algumas hipóteses e indicar as mais prováveis.

\subsubsection{Erosão geoquímica da rocha e formação de dolinas com posterior desenvolvimento de hidromorfia}

A formação de depressões fechadas como em Françoso et al. (1974), Reeves et al. (1975) e Espindola et al. (1981), por um fraturamento mais intenso da rocha, dissolução de uma rocha mais solúvel em profundidade, no caso aqui estudado do calcário basal de aproximadamente $2,5 \mathrm{~m}$ de espessura, podem ocorrer, mas não foi 
constatado. Certamente, antes da formação das depressões na região há uma expansão diferenciada do pacote de sedimentos e das alteritas, devido à presença de folhelho montmorilonítico no pacote de sedimentos da Formação Irati. Além disto o calcário basal é dolomítico, apresenta-se muito silificado e possui abundância de lâminas milimétricas e submilimétricas de sílex em sua constituição, reduzindo muito a sua solubilidade.

A formação de depressões, por um fraturamento mais intenso da rocha, com dissolução do calcário basal de aproximadamente $2,5 \mathrm{~m}$ de espessura, pode ocorrer, mas certamente antes haverá uma expansão diferenciada do pacote de sedimentos mais alteritas, devida à presença de folhelho montmorilonítico no pacote de sedimentos da Formação Irati.

A formação de depressões semelhantes a dolinas, pode não envolver o rebaixamento do terreno, sendo neste caso mais provável que os solos desenvolvidos sobre esta tenham boa drenagem e não favoreça o desenvolvimento muito diferenciado dos solos e estejam localizadas em relevo mais movimentado, com discordância pedológica, de alteritas e sedimentos.

\subsubsection{Erosão geoquímica do solo com formação da depressão e posterior processo hidromorfia acelerando o processo de rebaixamento do relevo}

Não se pode afirmar que ocorra um processo de afundamento geoquímico do solo que explique a formação das depressões (Bocquier et al., 1977; Boulet et al., 1977; Chauvel el al, 1977; Millot, 1977; Nahon \& Millot, 1977; Filizola \& Boulet; 1993), dada a magnitude de variação no nível de base observado no campo. As 3 linhas de sílex seguidas entre os perfis estudados concordantes com o relevo, a despeito da diferença de nível de 2,40 entre o perfil 1 e 4, tanto nos volumes de solo, como nos de alteração, comprovam que o afundamento geoquímico do solo é secundário no desenvolvimento da depressão. $\mathrm{O}$ material de origem mais preservado no centro da depressão, na base dos perfis 2 e principalmente 3 e 4 , dificulta a drenagem, sendo mais provável que a hidromorfia se estabeleceu antes do afundamento geoquímico do solo (incipiente no caso estudado). 
3.4.3 Dobramentos atectônicos ou de intemperismo favorecidos por uma silicificação diferencial da rocha e condicionando o desenvolvimento da depressão e sistemas pedológicos associados

Observou-se nas diferentes exposições de material geológico, que existe uma expansão tanto dos sedimentos como dos volumes de alterita e de solos. O pacote rítmico de folhelho pirobitominoso e calcário silificado possui uma expansão crescente à medida que se aproxima das alteritas e solos. Diferenças nesta expansão não foram constatadas nos sedimentos mais consolidados medidos, expandindo-se homogeneamente. As exposições onde aparentemente existe uma maior diferença não foram medidas, pela ausência de exposições recentes e dificuldades de acesso ou medição com o teodolito.

A exposição de sedimentos próxima ao perfil 1 localizado a montante da depressão, foi medido precariamente, dadas as dificuldades de acesso; aparentemente não existe diferença de expansão dos sedimentos mais consolidados, mas existe diferença de espessura do pacote de alteritas mais solos de aproximadamente 1,5 metros em aproximadamente 40 metros horizontais que margeiam esta exposição, sendo o perfil com uma diferenciação pedológica dificil de ser estimada dada a distância e "sujeira do barranco" (figura 61).

Dentro das trincheiras, na cobertura pedológica estudada, como citado anteriormente, acompanhou-se o padrão de alteração das alteritas e lâminas de sílex concordantes com o relevo. Embora Amaral (1971) cite os dobramentos atectônicos provocados pela expansão do folhelho contendo montmorilonita, não comenta nada sobre a diferenciação de solos. Relacionada a esta, no entanto, a partir das observações e medidas realizadas, pode-se levantar a seguinte hipótese para a formação da depressão e a diferenciação dos solos:

Áreas mais silificadas, com lajes ou leitos de sílex mais contínuos $e$ espessos, ou distantes de fraturamentos ou inversões de "mergulhos", estariam mais preservadas desta expansão da montmorilonita; a menor expansão dos sedimentos em 
algumas dezenas de metros induziria a formação da depressão. A hidromorfia se estabeleceria condicionando a diferenciação de solos, onde a ferrólise de Brinkman (1969), atuaria no desmonte dos argilominerais e saída de Fe e Si em formas mais solúveis, sendo o processo responsável pela mudança de cor de avermelhado para amarela, chegando as cores neutras de redução no domínio hidromórfico, bem como a elevação na concentração relativa de quartzo no horizonte $E$, e a elevação da fração silte pela degradação das frações areias constituídas de sílex e pirita finamente dividida.

$O$ Fe está sendo perdido em solução, parte nas águas de drenagem interna dos solos, parte se concentrando nos volumes de alteritas na base dos perfis, neoformando argilominerais ricos em $\mathrm{Fe}$, com cores esverdeadas e azuladas, com domínios crescentes em direção ao hidromorfismo mais acentuado no centro da depressão. 


\section{CONCLUSÕES}

1. O processo mais provável de formação da depressão estudada está relacionado à hipótese de dobramentos atectônicos oriundos da expansão da montmorilonita dos folhelhos. Áreas mais silificadas ou mais distantes de prováveis contatos de maior fraturamento, devido às inversões ou maiores gradientes de mudança no nível de base, estariam mais preservadas deste tipo de dobramento. Estas áreas mais preservadas estariam nas posições mais baixas das depressões fechadas ou abertas que ocorrem sobre a Formação Irati.

2. O processo de diferenciação pedológica, em solos bem drenados, avermelhados ou com matizes mais amarelados e solos mais acinzentados com feições típicas de hidromorfismo, seria secundário, condicionada pelo desenvolvimento de hidromorfia em direção à base das depressões. A erosão geoquímica dos solos, neste caso, tem uma atuação secundária no desenvolvimento do relevo.

3. Estudos mais detalhados, envolvendo geologia estrutural e macro e micromorfologia de solos e alteração, em outras depressões semelhantes, em diferentes estágios de desenvolvimento seriam importantes para se compreender melhor a interação dos sistemas pedológicos associados e as suas relações com o modelado na Formação Irati. 


\section{REFERÊNCIAS BIBLIOGRÁFICAS}

AMARAL, S. E. Geologia e Petrologia da Formação Irati (Permiano) no Estado de São Paulo. Boletim Instituto de Geografia e Astronomia, n.2, p.3-82, 1971.

BARBOSA, O. \& GOMES, F. A. Pesquisa do petróleo na bacia do rio Corumbataí, Estado de São Paulo. Boletim da Divisão de Geologia Mineralogia, n.171, p.1$40,1958$.

BESOAIN, E. Mineralogia de arcillas de suelos, San José: IICA, 1985, 1205 p..

BOCQUIER, G.; ROGNON, P.; PAQUET, H.; MILLOT, G. Géochimie de la surface et formes du relief II. Interpretation pedologique des depressions annulaires entourant certains inselbergs. Science Geologique. Bulletin, v.30, n.4, p.245-253, 1977.

BOULET, R.; BOCQUIER, G.; MILOT, G. Géochimie de la surface et forme du relief. I Déséquilibre pedobioclimatique dans les covertures pédologiques de l'Afrique tropicale de l'ouest et son rôle dans l'aplanissement des reliefs. Science Geologique. Bulletin, v.30, n.4, p.235-243, 1977.

BREWER, R. Fabric and mineral analyses of soils. New York: Robert E. Krieger Publishing Company. Huntington, 1976, 482p.

BRINDLEY, G. W. \& BROWN, G. Crystal structures of clay minerals and their Xray identification. Mineralogical Society, London, 1980.

BRINKMAN, R. Ferrolysis, a hidromorphic soil forming process. Geoderma, n. 3, p. 199-206, 1969/1970.

BRINKMAN, R. Ferrolysis, a soil-forming process in hydromorphic conditions. Agric. Res. Res. Rep., 887, Puduc, Wagningen, 1979, 106p. 
CABRERA-MARTINEZ, F; HARRIS, W. G.; CARLISLE, V. W.; COLLINS, M. E. Evidence for clay translocation in coastal plains soils with sandy;loamy boudaries. Soil Science Sociaty of America Journal, Madison, v 53: 1108-1114, 1988.

CAMARGO, O. A. de; MONIZ, A. C.; JORGE, J. A. ; VALADARES, J. M. A. S. Métodos de análise química, mineralógica e física de solos do Instituto Agrônomico de Campinas. Campinas: Instituto Agrônomico, 1986. 94p. (Boletim técnico 106). CASTRO, S. S. Impregnação de amostras de solo para confecção de lâmina delgada. B. Informativo da Sociedade Brasileira de Ciência do Solo, v.10, n.2, p.44, 1985.

CHAUVEL, G. Recherches sur la transformation des sols ferrallitiques dans la zone tropicale a saisons constrastées. ORSTOM - sér. Travaux et Document, n.62, 532p., 1977.

COMISSÃO DE SOLOS. Levantamento de reconhecimento dos solos do Estado de São Paulo. Rio de Janeiro: Ministério da Agricultura, CNEPA, SNPA, 1960. 634p. (Boletim 12).

DELVIGNE, J. Micromorfologia de alteração. Apostila de curso, 169 p., 1983.

ESPÍNDOLA, C. R.; GALHEGO, H. R.; GARCIA, G. J. Desenvolvimento de bacias hidromórficas fechadas em superficies de latossolos argilosos. Notícia Geomorfológica, v.21, n.41, p.131-143, junho 1981.

FILIZOLA, H. F. \& BOULET, R. Une èvaluation de la vitesse de l'érosion géochimique á partir de l'etude de dépressions fermées sur roches sedimentaires quartzokaoliniques au Brésil. Comptes Rendus de I'Academie des Sciences de Paris, n.316, sér. II, p.693-700, 1993.

FRANÇOSO, S. S. C.; AILlAUD, C.; QUEIROZ NETO, J. P. de. Depressões doliniformes do platô de Itapetininga, SP. Tentativa de Interpretação. In: CONGR. BRASILEIRO DE GEOLOGIA, 28. Anais. p.85-90. 1974.

HILL, E. S. Elements of Structural Geology. John Wilew \& Sons, Inc, N. Y, 1963, p 71. 
IPT Mapa Geológico do Estado de São Paulo. São Paulo: Divisão de Minas e Geologia Aplicada do Instituto de Pesquisas Tecnológicas do Estado de São Paulo, 1981a. Escala 1:1.000.000.

IPT Mapa Geomorfológico do Estado de São Paulo. São Paulo: Divisão de Minas e Geologia Aplicada do Instituto de Pesquisas Tecnológicas do Estado de São Paulo, 1981b. Escala 1:1.000.000.

JACKSON, M. L . Soil chemical analysis. Advanced course. Madison, Wisconsin, 1969. 894p.

LANDIM, P. M. B. Deformações por compactação em sedimentos da Formação Irati. Boletim da Sociedade Brasileira de Geologia, v. 14 n. 1/2: 53-59, 1965.

LEMOS, R. C.e SANTOS, R. D. Manual de descrição e coleta de solo no campo. $2^{\text {a }}$ Edição. Campinas: Soc. Brasileira de Ciência do Solo e SNLCS, 1984. 46p.

MÉRING, J. L' interference des rayons $\mathrm{X}$ dans les systemes a stratification desordonee: Acta Crystallographica n. 3: 371-377, 1949.

MILLOT, G. Géochimie de la surface et formes du relief. Présentation. Science Geologique. Bulletin, v.30, n.4, p. 229-233, 1977.

MONIZ, A. C. (Coord.). Elementos de Pedologia. Rio de Janeiro: Livros Técnicos e Científicos, $1975.459 \mathrm{p}$.

NAHON, D. \& MILLOT, G. Géochimie de la surface et forme du relief. V.

Enfoncement géochimique des cuirasses ferrugineuses par épigenie du manteau d'alteration des roches mères gréseuses. Influence sur le paysage. Science Geologique. Bulletin, v.30, n.4, p.275-282, 1977.

OLIVEIRA, J. B. de; ALFONSI, R. R.; PEDRO JÚNIOR, M. J. Regimes hídricos e térmicos dos solos do Estado de São Paulo. In: CONGRESSO BRASILEIRO DE CIÊNCIA DO SOLO, 15. Anais. Campinas, Sociedade Brasileira de Ciência do Solos,1976. p. 359-362. 
OLIVEIRA, J. B.; PRADO, H. Carta pedológica semidetalhada do Estado de São Paulo. São Paulo: Secretaria da Agricultura, 1989. Folha de Piracicaba, Escala $1: 100.000$.

REEVES, R. G.; ANSON, A.; LANDEM, D. Terrain and Minerals: Assessment and Evaluation. American Society of Photogrammetry. Manual of Remote Sensing. Interpretations and Applications. Virginia: Falls Church, 1975. v. 2, cap.16, p.1107-1351.

STOOPS, G. \& JONGERIUS, A. Proposal for a micromorphological classification of soil materials. I. A classification of the related distribuion of fine and coarse particles. Geoderma, 1975.

J VAN RAIJ, B; QUAGGIO, J. A.; CANTARELLA, H.; FERREIRA, M. E.; LOPES, A. $\mathrm{S}$; BATAGLIA, $\mathrm{O}$. A análise química do solo para fins de fertilidade. Campinas: Fundação Cargill, 1987. 165p. 


\section{ANEXOS}

Quadro 1. Análise granulométrica

\begin{tabular}{|c|c|c|c|c|c|c|c|c|c|}
\hline HORIZONTE & PROF.(cm) & $\begin{array}{r}\text { AREIA MUITO } \\
\text { GROSSA }\end{array}$ & $\begin{array}{r}\text { AREIA } \\
\text { GROSSA }\end{array}$ & $\begin{array}{l}\text { AREIA } \\
\text { MEDIA }\end{array}$ & $\begin{array}{r}\text { AREIA } \\
\text { FINA }\end{array}$ & $\begin{array}{r}\text { AREIA } \\
\text { MUITO FINA }\end{array}$ & $\begin{array}{l}\text { AREIA } \\
\text { TOTAL }\end{array}$ & SILTE & ARGILA \\
\hline & & \multicolumn{8}{|c|}{$\%$} \\
\hline P1 Ap & 10,0 & 1 & 1 & 3 & 11 & 8 & 24 & 35 & 41 \\
\hline$\overline{\mathrm{P1} \text { Bt1 }}$ & 50,0 & 1 & 1 & 3 & 9 & 2 & 16 & 30 & 54 \\
\hline P1 Bt2 & 90,0 & 1 & 1 & 2 & 6 & 2 & 12 & 27 & 61 \\
\hline P1 Bt3 & 130,0 & 1 & 1 & 2 & 3 & 1) & 8 & 31 & 71 \\
\hline $\mathrm{P1Cr}$ & 180,0 & 1 & 1 & 1 & 1 & 1 & 5 & 23 & 72 \\
\hline $\mathrm{P1Cr}$ & 195,0 & 2 & 1 & 1 & 0 & 0 & 4 & 21 & 75 \\
\hline P1Cr3 & 210 & 3 & 2 & 2 & 1 & 0 & 8 & 25 & 67 \\
\hline P2 Ap & 8,0 & 2 & 3 & 5 & 14 & 5 & 29 & 36 & 35 \\
\hline P2AB & 26,0 & 2 & 3 & 6 & 16 & 6 & 33 & 32 & 35 \\
\hline P2 BA & 44,0 & 2 & 2 & 4 & 10 & 4 & 22 & 33 & 45 \\
\hline P2 Bt1 & 61,5 & 1 & 1 & 2 & 5 & 2 & 11 & 20 & 69 \\
\hline P2 Bt2 & 94,0 & 1 & 1 & 1 & 3 & 2 & 8 & 21 & $\overline{71}$ \\
\hline P2 CB & 128 & 2 & 2 & 2 & 4 & 1 & 11 & 21 & 68 \\
\hline $\mathrm{P2}$ Cr1 & 145,5 & 3 & 3 & 2 & 4 & 2 & 14 & 19 & 67 \\
\hline P3 AP & 5,0 & 2 & 3 & 2 & 15 & 7 & 33 & 34 & 33 \\
\hline P3 AE & 15,0 & 2 & 3 & 5 & 17) & 3 & 31 & 36 & 33 \\
\hline P3E & 24,0 & 3 & 3 & 5 & 11) & 6 & 27 & 38 & 35 \\
\hline P3 BE & 35,5 & 3 & 3 & 2 & 10 & 4 & 24 & 27 & 49 \\
\hline$\overline{\text { P3 BTG1 }}$ & 55,5 & 1 & 1 & 4 & 5 & 2 & 11 & 22 & 67 \\
\hline P3 BTG2 & 80,0 & 1 & 1 & 6 & 5 & 3 & 12 & 25 & 63 \\
\hline$\overline{\text { P4 Ap }}$ & 10,0 & 1 & 2 & 2 & 5 & 3 & 13 & 41 & 46 \\
\hline P4 E & 28,0 & 0 & 1 & 1 & 4 & 1 & 7 & 46 & 47 \\
\hline P4 Btg & 48,0 & 0 & 0) & 1 & 2 & 1 & 4 & 32 & 64 \\
\hline P4 Btgf & 75,0 & 1 & 0 & 1 & 2 & 1 & 5 & 31 & 64 \\
\hline P4 BtgV & 100,0 & 0 & 0 & 1 & 2 & 1 & 4 & 24 & $\overline{72}$ \\
\hline P4 BCtgv & 140,0 & 0 & 0 & 1 & 2 & 1 & 4 & 29 & 67 \\
\hline P4 Cr1 & 170,0 & 0 & 0 & 1 & 2 & 1 & 4 & 22 & 74 \\
\hline P4 Cr2 & 195,0 & 4 & 4 & 3 & 4 & 2 & 17 & 18 & 65 \\
\hline
\end{tabular}


Quadro 2. Complexo sortivo

\begin{tabular}{|c|c|c|c|c|c|c|c|c|c|c|c|c|c|}
\hline HORIZONTE & PROF.(cm) & $\mathrm{pH} H 2 \mathrm{O}$ & Mo & $\bar{P}$ & $\bar{k}$ & $\overline{C a}$ & $\mathbf{M g}$ & $\overline{\mathbf{A l}}$ & $\mathrm{H}+\mathrm{AI}$ & SB & $\bar{T}$ & $\bar{v}$ & $\mathbf{m}$ \\
\hline & & & \% & ppm & \multicolumn{7}{|c|}{ cmol/kg solo } & $\%$ & $\%$ \\
\hline$\overline{A p}$ & 10 & 6,9 & 3,1 & 34 & 0,46 & 9,7 & 3,4 & 0,0 & 1,8 & 13,60 & 15,40 & 88,0 & \\
\hline$\overline{B+1}$ & 50 & $\overline{7,4}$ & 2,3 & 13 & 0,17 & $\overline{9,8}$ & 2,9 & 0,0 & 1,6 & 12,90 & 14,50 & 89,0 & \\
\hline Bt2 & 90 & 6,8 & 1,1 & 10 & 0,13 & 12,0 & 2,3 & 0,0 & 2,2 & 14,50 & 16,70 & 87,0 & \\
\hline Bt3 & 140 & 7,3 & 0,8 & 14 & 0,11 & 9,9 & 2,5 & 0,0 & 1,8 & 12,50 & 14,30 & \begin{tabular}{|l|}
87,0 \\
\end{tabular} & \\
\hline Cr1 & 195 & $\overline{6,6}$ & 0,7 & 9 & 0,21 & 8,9 & 2,5 & 0,0 & 2,5 & 1,70 & 14,20 & 82,0 & \\
\hline Cr2 & 210 & 7,2 & 0,7 & 6 & 0,17 & 7,7 & 2,3 & 0,0 & 1,6 & 10,20 & 11,80 & \begin{tabular}{|l|}
86,0 \\
\end{tabular} & \\
\hline Ap & 8,0 &, 4 & 2,2 & 27 & 0,12 & 4,0 & 1,2 & 0,1 & 5,6 & 5,30 & 10,90 & $|49,0|$ & \\
\hline$\overline{A B}$ & 26,0 & 5,8 & 1,4 & 4 & 0,05 & 4,3 & 0,9 & 0,1 & 5,7 & 5,30 & 11,00 & \begin{tabular}{|l|}
48,0 \\
\end{tabular} & \\
\hline T2 BA & 44,0 & 5,8 & 1,1 & 2 & 0,05 & 6,3 & 1,1 & 0,0 & 4,4 & 7,50 & 11,90 & 63,0 & \\
\hline $\mathrm{Bt1}$ & 61,5 & 6,2 & 0,8 & & \begin{tabular}{|l|}
0,11 \\
\end{tabular} & 10,2 & 2,3 & 0,0 & 4,5 & 12,60 & 17,11 & 74,0 & \\
\hline Bt2 & $\overline{94,0}$ & 6,3 & 1,1 & 4 & 0,14 & 8,9 & 2,8 & 0,0 & 4,2 & 11,80 & 16,00 & 74,0 & \\
\hline $\mathrm{CB}$ & $\overline{128}$ & 6,0 & 0,6 & 3 & 0,15 & 7,2 & 2,8 & 0,6 & 3,8 & 10,20 & 14,00 & 73,0 & \\
\hline Cr1 & 145,5 & 5,9 & 0,6 & 2 & \begin{tabular}{|l|}
0,19 \\
\end{tabular} & 8,7 & 3,4 & 0,2 & 4,4 & 12,30 & 16,70 & 74,0 & 2 \\
\hline T3 Ap & 5,0 & 5,5 & 2,2 & 15 & 0,25 & 6,5 & 2,1 & 0,1 & 5,0 & 8,90 & 13,90 & 64,0 & 1, \\
\hline T3 AE & $\overline{15,0}$ & 5,4 & 1,7 & 5 & \begin{tabular}{|l|}
0,08 \\
\end{tabular} & 4,2 & 1,0 & 0,1 & 5,2 & 5,30 & 10,50 & 50,0 & 2 \\
\hline $\bar{E}$ & $\overline{24,0}$ & 5,7 & 1,1 & 3 & 0,08 & 3,8 & 0,9 & 0,3 & 5,0 & 4,80 & 9,80 & 49,0 & 0 \\
\hline T3 BE & 35,5 & 5,5 & 1,1 & 6 & \begin{tabular}{|l|}
0,07 \\
\end{tabular} & 4,2 & 1,2 & 0,1 & 5,4 & 5,50 & 10,90 & \begin{tabular}{|l|}
50,0 \\
\end{tabular} & \\
\hline T3 Btg1 & 55,5 & 5,3 & 0,8 & 4 & \begin{tabular}{|l|}
0,14 \\
\end{tabular} & 3,5 & 1,7 & 3,0 & 9,2 & 5,30 & 14,50 & 37,0 & 36 \\
\hline T3 Btg2 & 80,0 & 5,5 & 0,8 & 6 & \begin{tabular}{|l|}
0,17 \\
\end{tabular} & 5,0 & 2,3 & 0,1 & 6,4 & 7,50 & 13,90 & \begin{tabular}{|l|}
54,0 \\
\end{tabular} & \\
\hline T4 Ap & 10,0 & 5,0 & 2,1 & 16 & \begin{tabular}{|l|}
0,13 \\
\end{tabular} & 3,8 & 1,5 & 1,5 & 8,8 & 5,50 & 14,30 & 38,0 & 6 \\
\hline T4E & $28, C$ & 4,3 & 0,8 & 11 & \begin{tabular}{|l|}
0,11 \\
\end{tabular} & 1,5 & 0,9 & 2,2 & 8,0 & 2,70 & 10,60 & 25,0 & 46 \\
\hline T4 Btg & $48, C$ & 4,2 & 0,9 & 14 & \begin{tabular}{|l|}
0,23 \\
\end{tabular} & 1,4 & 2,3 & 6,6 & \begin{tabular}{l|l|}
34,7 \\
\end{tabular} & 4,10 & 38,80 & 11,0 & 62 \\
\hline Btgf & $75, c$ & 4,5 & 0,7 & 6 & \begin{tabular}{|l|}
0,21 \\
\end{tabular} & 0,8 & 1,8 & 6,0 & 38,6 & 3,00 & 45,60 & 7,0 & 67 \\
\hline BCgv & $140, c$ & 6,5 & 0,7 & & \begin{tabular}{|l|}
0,17 \\
\end{tabular} & 5,2 & 13,5 & 0,1 & 3,1 & 19,30 & 22,40 & 86,0 & \\
\hline T4 Cr1 & $170, c$ & 7,0 & 0,6 & & \begin{tabular}{|l|}
0,14 \\
\end{tabular} & 7,1 & 15,5 & 0,0 & 1,8 & 23,20 & 25,00 & 93,0 & \\
\hline $4 \mathrm{Cr} 2$ & $\overline{195, c}$ & $7, c$ & \begin{tabular}{|l|}
0,7 \\
\end{tabular} & 13 & \begin{tabular}{|l|}
0,09 \\
\end{tabular} & \begin{tabular}{|l|}
10,2 \\
\end{tabular} & 12,0 & 0,0 & 1,6 & 22,80 & 24,40 & 93,0 & \\
\hline
\end{tabular}


Quadro 3. Ataque sulfú rico

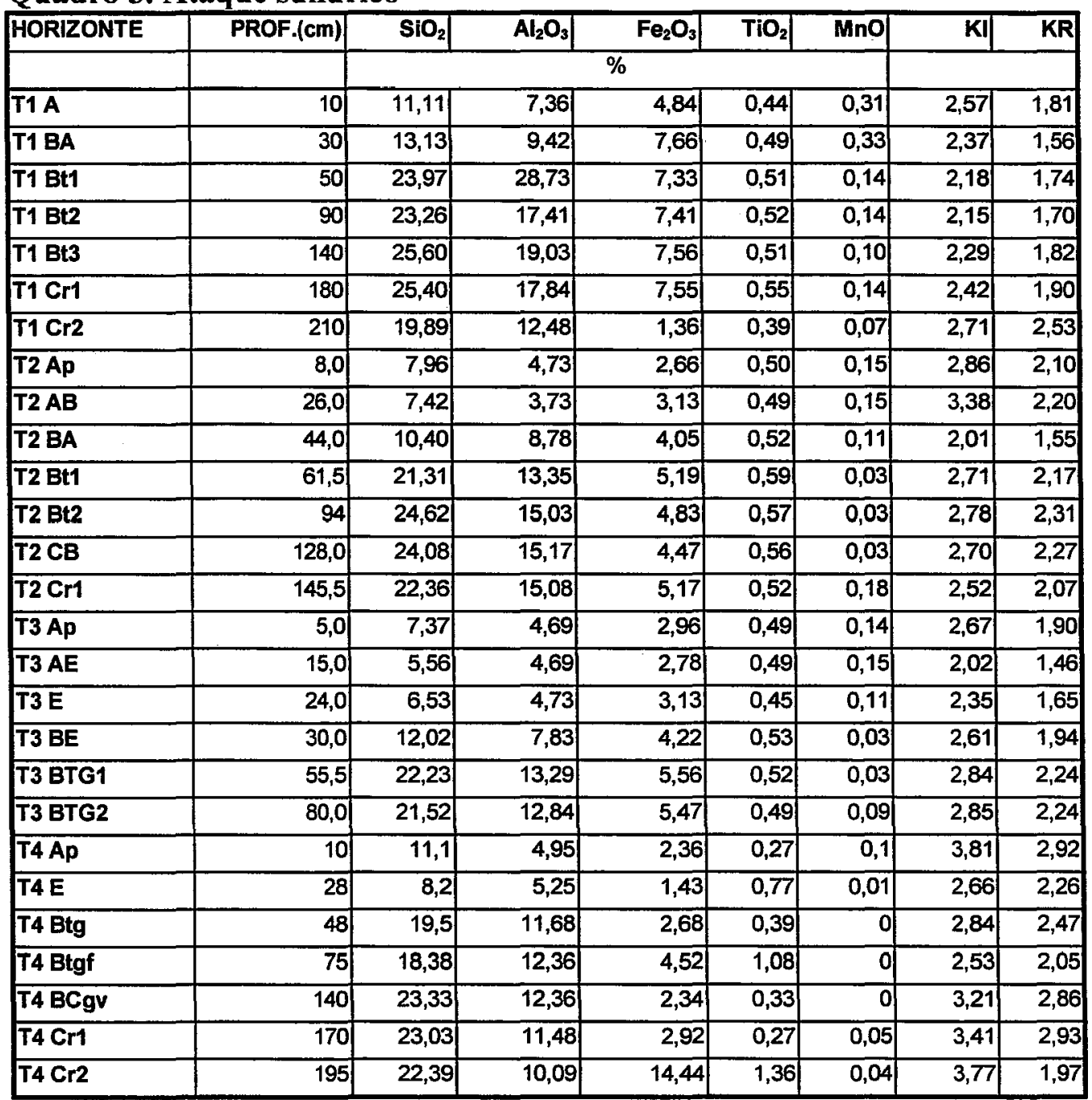

